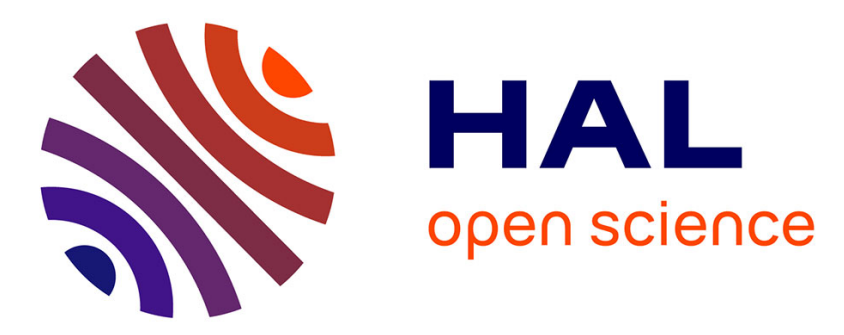

\title{
Synthesis and Biological Activities of Naturally Functionalized Polyamines: An Overview
}

Jean Michel Brunel, Sophie Négrel

\section{To cite this version:}

Jean Michel Brunel, Sophie Négrel. Synthesis and Biological Activities of Naturally Functionalized Polyamines: An Overview. Current Medicinal Chemistry, 2021, 28 (17), pp.3406-3448. 10.2174/0929867327666201102114544 . hal-03367292

\section{HAL Id: hal-03367292 \\ https://hal.science/hal-03367292}

Submitted on 11 Oct 2021

HAL is a multi-disciplinary open access archive for the deposit and dissemination of scientific research documents, whether they are published or not. The documents may come from teaching and research institutions in France or abroad, or from public or private research centers.
L'archive ouverte pluridisciplinaire HAL, est destinée au dépôt et à la diffusion de documents scientifiques de niveau recherche, publiés ou non, émanant des établissements d'enseignement et de recherche français ou étrangers, des laboratoires publics ou privés. 


\title{
Synthesis and biological activities of natural functionalized polyamines: An overview
}

\author{
Sophie Négrel and Jean Michel Brunel*
}

1 Aix Marseille Univ, INSERM, SSA, MCT, 13385 Marseille, France. E-mail : bruneljm@yahoo.fr

\begin{abstract}
Recently, extensive researches have emphasized the fact that polyamines conjugates are becoming important in all the biological and medicinal fields. In this review we will focus our attention on natural polyamines and highlight recent progress in both fundamental mechanism studies and interest for the development and application for a therapeutic human use of polyamine derivatives.
\end{abstract}

Keywords: natural polyamines, antimicrobial activities, toxins, marine drugs

\section{I-Introduction}

The discovery of new compounds from nature is still one of the most efficient methods for finding lead molecules for the development of pharmaceuticals. Thus, following the discovery of penicillin and among all the families of organic compounds encountered in nature, polyamines have long been neglected as potent molecules of biological interest. On a structural point of view, polyamines are polycationic molecules at physiological $\mathrm{pH}$ possessing a hydrocarbon backbone and multiple amino groups (Figure 1). [1] The first depicted polyamines were isolated from prokaryotic and eukaryotic organisms and possessing at least two amino groups as part of an aliphatic chain. [2, 3]

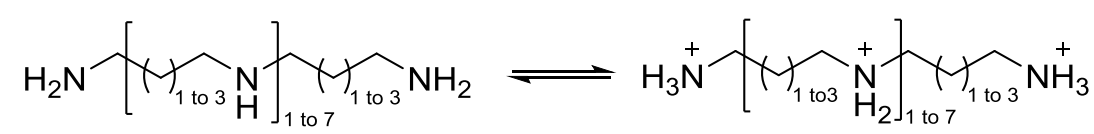

Figure 1. General structure of polyamines.

Therefore, due to the proximity of at least two $\mathrm{N}$-atoms in their structures, polyamines show chemical reactivities significantly different from monoamines as well as peculiar biological activities. [2] In this review, we will only focus our attention on natural polyamines and highlight the potent interest for the development and application for a therapeutic human use. 


\section{II-Natural aliphatic polyamines}

This class of polyamines constitutes the simplest class of polyamines naturally encountered and presenting $\mathrm{NH}_{2}$ groups separated by a small or large aliphatic chain. The most known polyamines are the aliphatic low-molecular weight putrescine $\mathbf{1}$, cadaverine $\mathbf{2}$, spermidine $\mathbf{3}$ and spermine $\mathbf{4}$ and, found in all eukaryotic and prokaryotic cells and involved in a wide range of biological phenomena from bacteria to plants and animals (

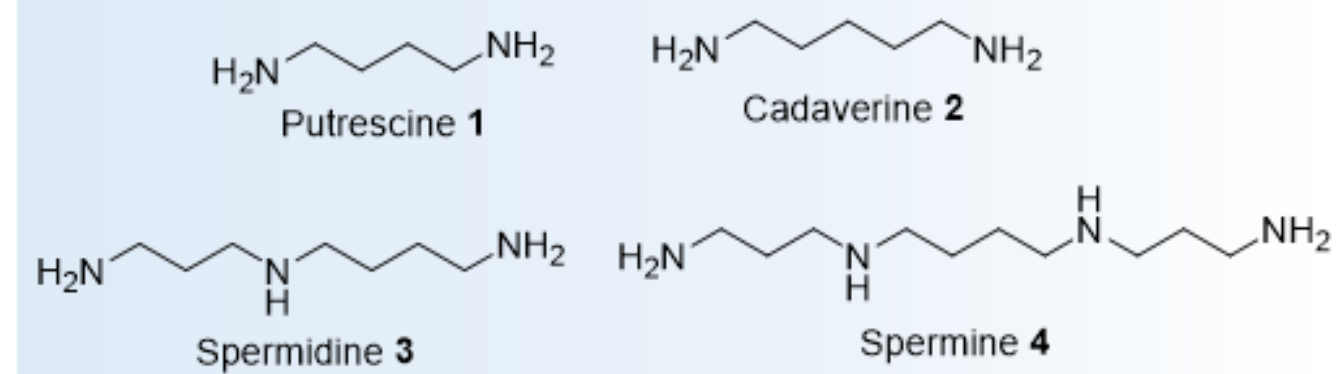

Figure 2).

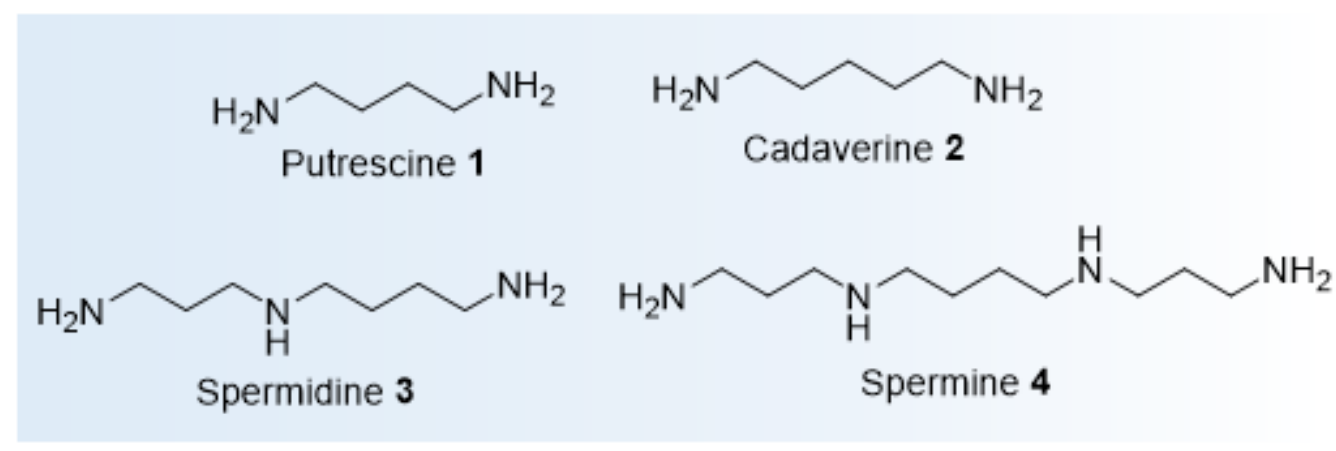

Figure 2. Structure of usual polyamines.

Thus, these polyamines are essential for cells growth due to their polybasic character conferring them a much higher affinity for acidic constituents and allowing reversible ionic interactions leading to the stabilization of macromolecules such as DNA, RNA, and proteins. [3-7] They can also act as second messengers in protein phosphorylation and hormonal signal transduction. [3, 8] Polyamines $\mathbf{1}, \mathbf{3}$ and $\mathbf{4}$ are synthesized in a highly regulated biochemical pathway as described in Figure 3 from ornithine 5 through a biomechanism involving ornithine decarboxylase, spermidine and spermine synthetases, spermidine/spermine $\mathrm{N}^{1}$ acetyltranferase and FAD-dependent polyamine oxidase. [3] On the other hand, cadaverine 2 came from lysine and its biosynthesis is catalyzed by a lysine decarboxylase via a pyridoxal phosphate-dependent decarboxylation. [8] 


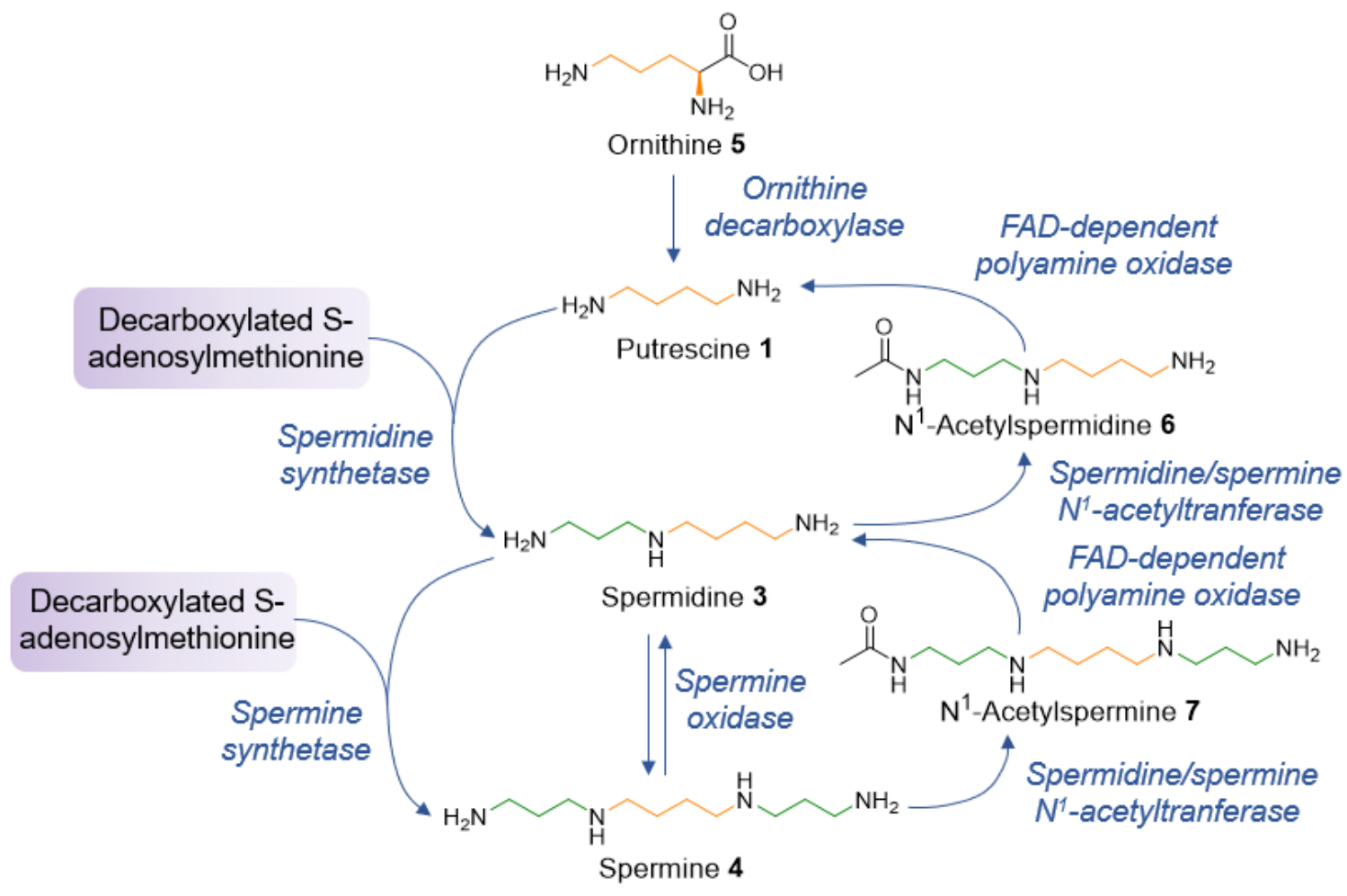

Figure 3. Biosynthesis pathway of putrescine 1, spermidine 3 and spermine 4 .

All these polyamines 1-4 were also demonstrated possessing antioxidant and antiapoptotic activities, involved in gut inflammatory processes, allergy as well in tumor growth. $[3,8,9]$ In this latter case, the specific biosynthesis pathway involved has been targeted for the development of antineoplastic therapy as well as cancer treatments. [3, 4]

Furthermore, less common polyamines such as norspermidine $\mathbf{8}$ and norspermine $\mathbf{1 0}$ were identified in plants Canavalia gladiata, Viciaradiata, V. sativa, in water-deficit stressed Medicago sativa L. (alfalfa) and photosynthetic Cyanidium caldarium acidothermophilic alga whereas thermospermine 13, homocaldopentamine 12 and homocaldohexaamine 15 were found in Brasenia schreberi osmotolerant alfalfa plant (Figure 4). [7, 8] All these polyamines have been widely studied and are involved in plant adaptation and development of stress tolerance. [8] 


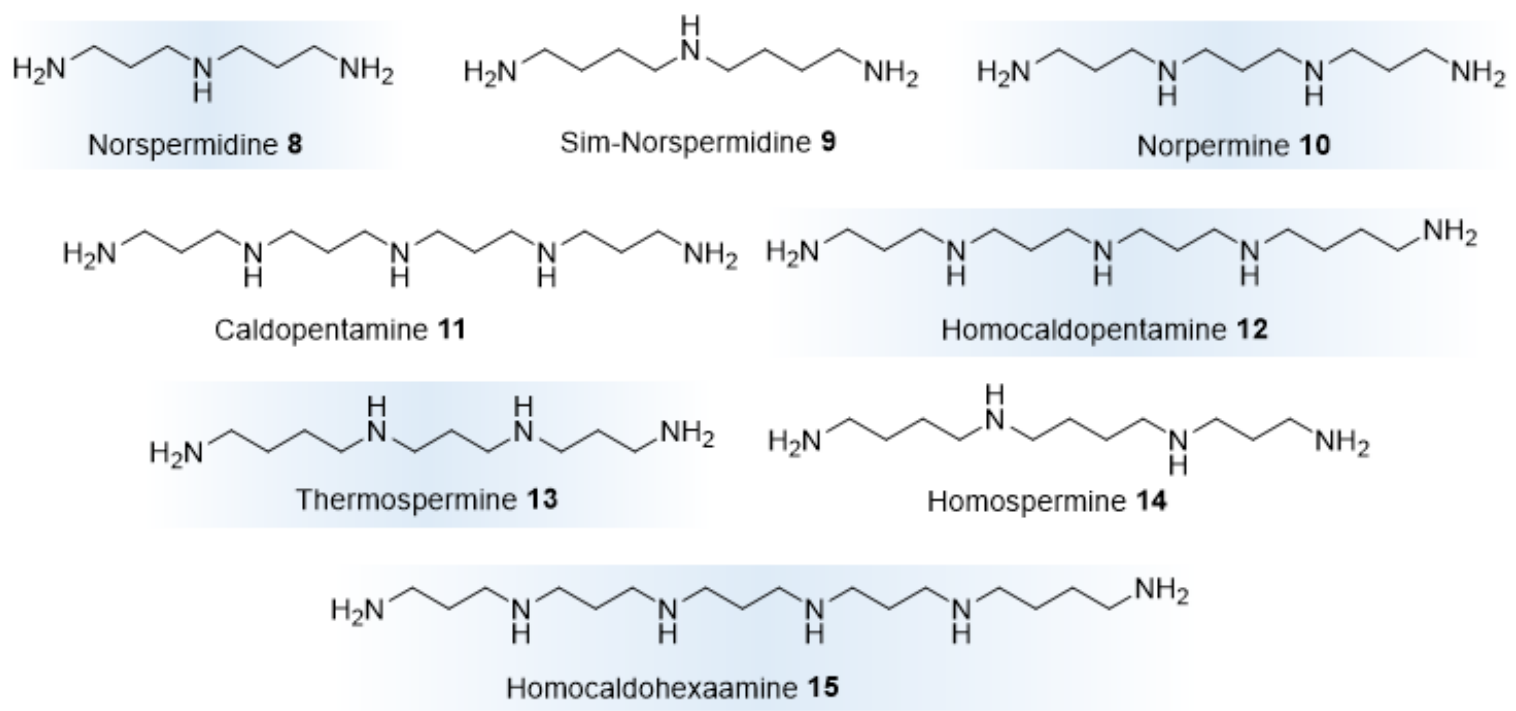

Figure 4. Chemical structures of unusual polyamines.

On the other hand, unicellular microalgae which refer to eukaryotic unicellular organisms containing chlorophyll are widely distributed in marine ecosystems. Their genomes are relatively diverse due to the complexity of their evolutionary origin which is also reflected in microalgal polyamine metabolic genes. [10] It is now well admitted that nitrogen is often the most limiting nutrient for microalgal growth in the oceans. [11] Therefore, the availability of dissolved organic nitrogen (DON) has a great impact on the primary productivity of marine ecosystems. [12] Thus, polyamines such as putrescine, spermidine, and spermine constitute one of the most important sources of DON in the oceans. [13] It is also known that local changes in polyamine concentration are usually related to algal blooms or the appearance of specific marine bacteria. Moreover, putrescine, spermidine, and spermine are typically found in most microalgae as common polyamines (Figure 4). Nevertheless, uncommon polyamines such as long-chain polyamines LCPAs have also been identified (Figure 5). [14-18]

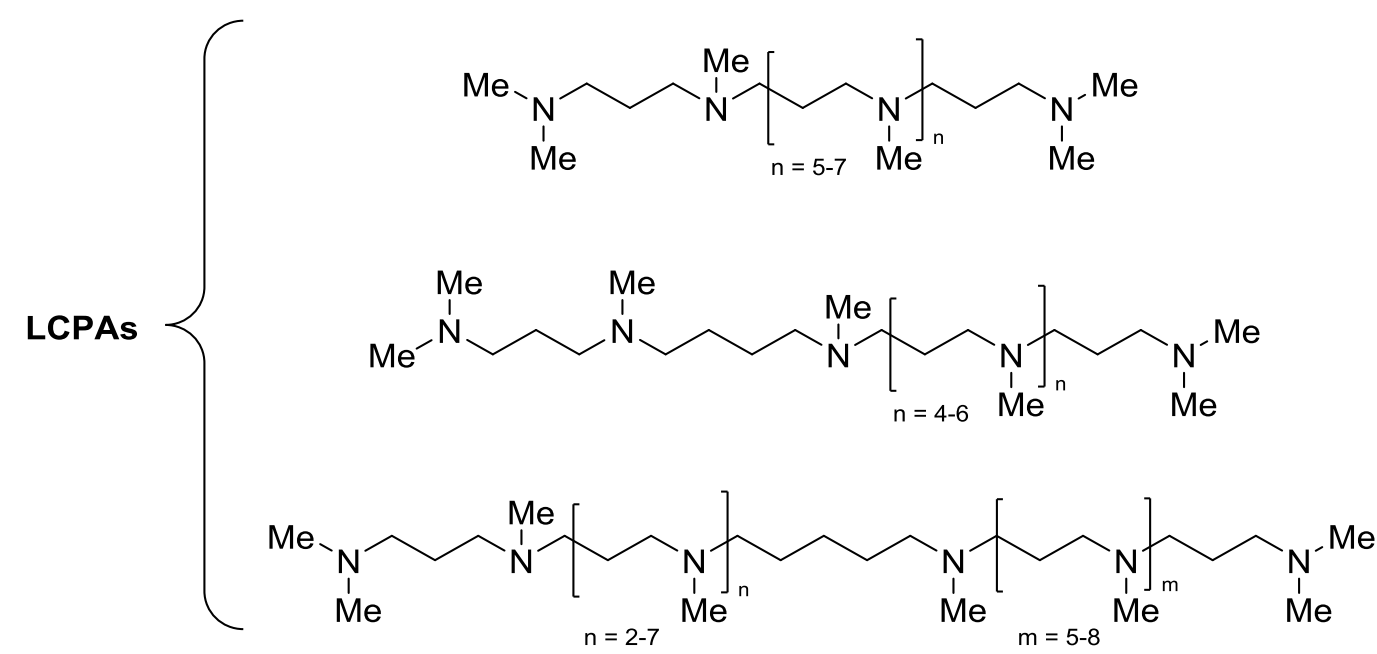


Figure 5. Molecular structure of uncommon long-chain polyamines encountered in diatoms.

In 2014, Burczyk et al. analyzed cell wall-conjugated polyamines in Scenedesmus and Chlorella Chlorophyceae having cell walls like higher plants, as well as similar conjugated polyamine composition including putrescine, spermidine, and spermine. [19] In contrast, the cell walls of diatoms are not made of cellulose. Their unique cell wall also contains very different polyamines compared to higher plants. Few polyamine synthetic enzymes have been well characterized especially from microalgae that produce uncommon polyamines. As encountered in most organisms, putrescine is the common precursor for the synthesis of other polyamines in microalgae. Thus, this diversity of polyamines could be derived from metabolic pathways comprising numerous polyamine synthase enzymes and hypothetically staged as indicated in Figure 6.

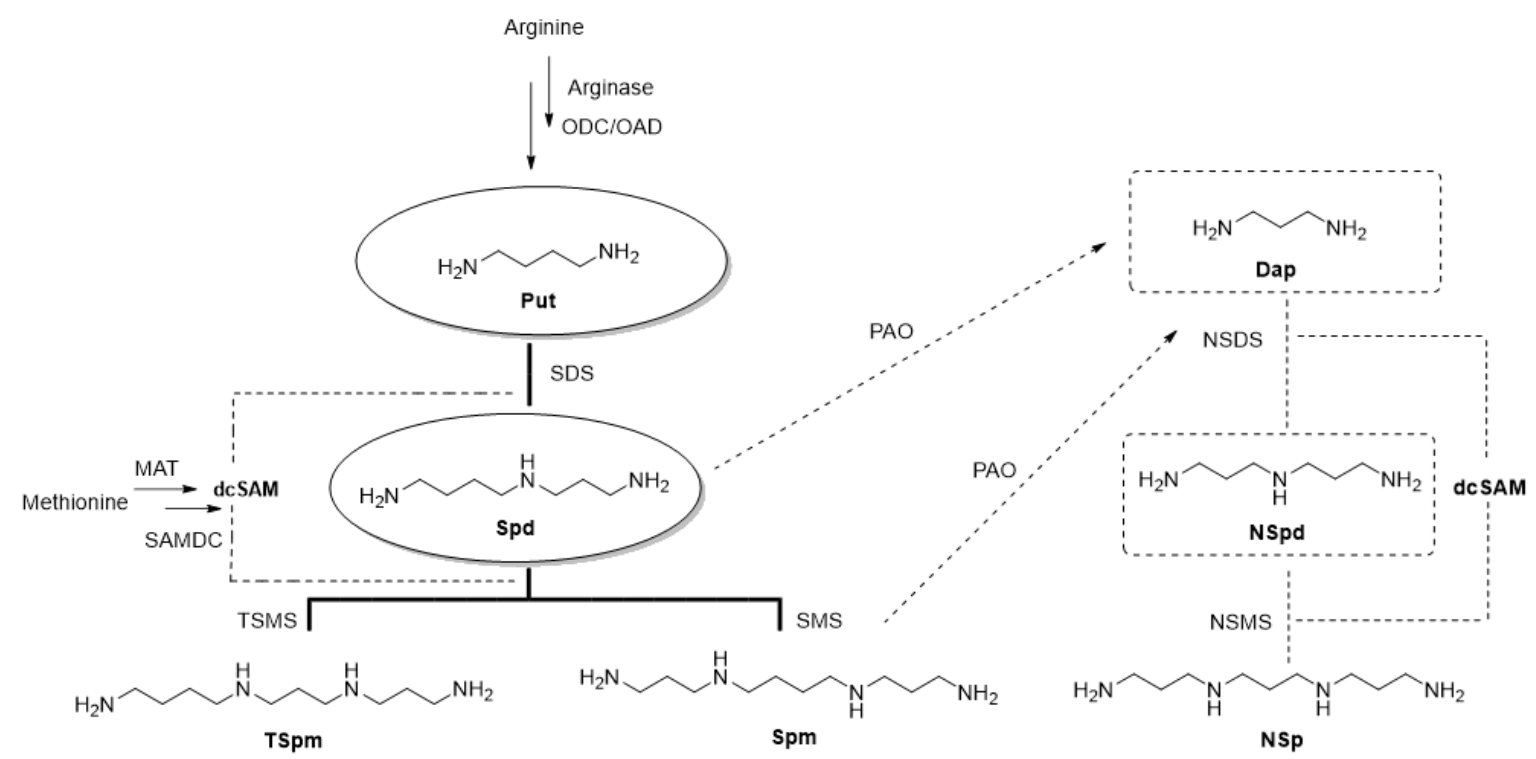

Figure 6. Postulated pathway for polyamine synthesis in microalgal cells. SAM, decarboxylated S-adenosylmethionine; Dap, diaminopropane; Put, putrescine; NSpd, norspermidine; Spd, spermidine; NSpm, norspermine; Spm, spermine; TSpm, thermospermine; ADC, arginine decarboxylase; MAT, methionine adenosyl transferase; NACPH, Ncarbamoylputrescine amidohydrolase; NSDS, nor-spermidine synthase; NSMS, norspermine synthase; ODC, ornithine decarboxylase; OAD, ornithine/arginine decarboxylase; PAO, polyamine oxidase; SAMDC, S-adenosylmethionine decarboxylase; SDS, spermidine synthase; SMS, spermine synthase.

Although norspermidine is widely present in most microalgae, the corresponding synthetic pathway remains unclear and could be synthesized from Dap and aspartate-semialdehyde (ASA) as illustrated in Figure 6. Finally, numerous studies have suggested that these uncommon polyamines may have the ability to kill cancer.Cells and found applications in the design of silica nanomaterials for potent medical applications. [16-18, 20, 21] Thus, it is 
envisioned that the microalgal enzymes involved in the synthesis of distinctive polyamines may be transferred to a target organism for mass production via a synthetic biology approach.

Nevertheless, since the discovery of natural aliphatic polyamines, plenty of other more complex natural polyamines such as toxins, iron scavengers or chemical factors were isolated from varied types of organisms as arthropods, mammals, fishes, fungi, bacteria, sponges and plant and exhibited various biological activities that will be depicted below.

\section{III-Polyamine Toxins}

\section{III-1 Argiotoxins from spider venoms}

Spider venoms are complex mixtures of peptides, proteins, and low molecular weight organic molecules such as polyamines. Thus, from venoms of orb weaver spiders Argiope lobata and Argiope aurantia were isolated two polyamine toxins namely Argiotoxin 636 (ArgTX-636, 16) and Argiotoxin 659 (ArgTX-659, 17) (Figure 77). [22-24]

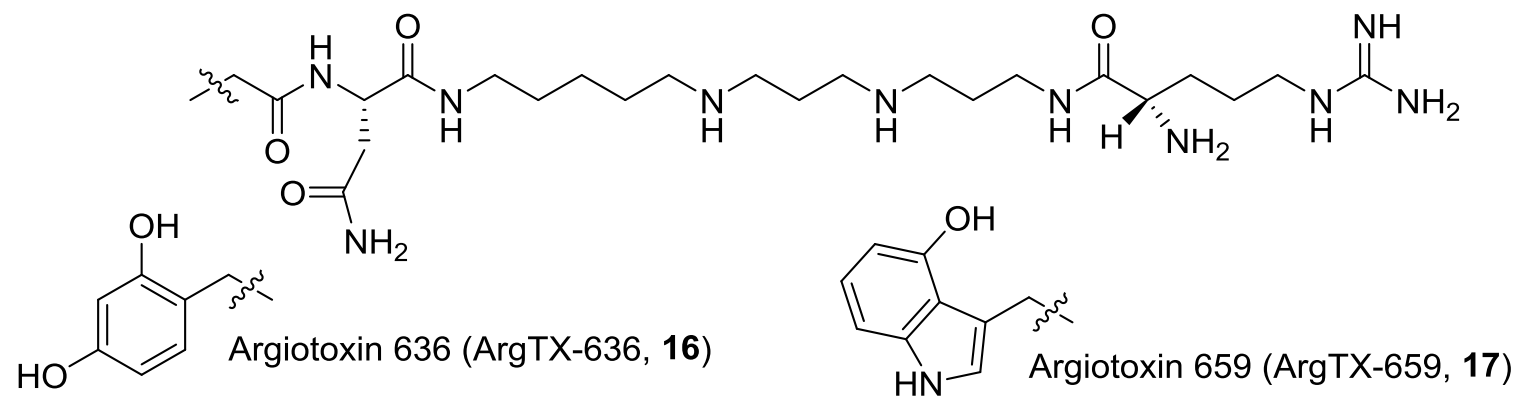

Figure 7. Structure of Argiotoxin 636 (ArgTX-636, 16) and Argiotoxin 659 (ArgTX-659, 17)

The synthesis of ArgTX-636 16 was firstly described by Shih et al., with 2 major building blocks and 10 steps. [25] Later, a chemical pathway achieving both ArgTx-636 16 and ArgTX-659 17 synthesis was depicted. [26] In 1995, Blagbrough et al. purposed a synthesis of ArgTX-636 16 in 14 steps including 4 different building blocks. [27] The more recent synthetic pathway using a solid-phase synthesis afforded ArgTX-636 16 in 2\% overall yield as described in Figure 8. [23] Thus, adsorption of the mono protected diamine 18 on a resin followed by two amino acid coupling reaction and a 2-trimethylsilylethoxycarbonyl amine protection provided $\mathbf{2 0}$ which lead to the synthesis of $\mathbf{2 2}$ through a FukuyamaMitsunobu alkylation strategy involving a series of protection and deprotection reactions. The Ns-protected amines were subsequently deprotected and the sample cleaved from the resin with removal of the Pbf, Boc, benzyl and Trt protecting groups to afford the expected ArgTX636 16. [23] 


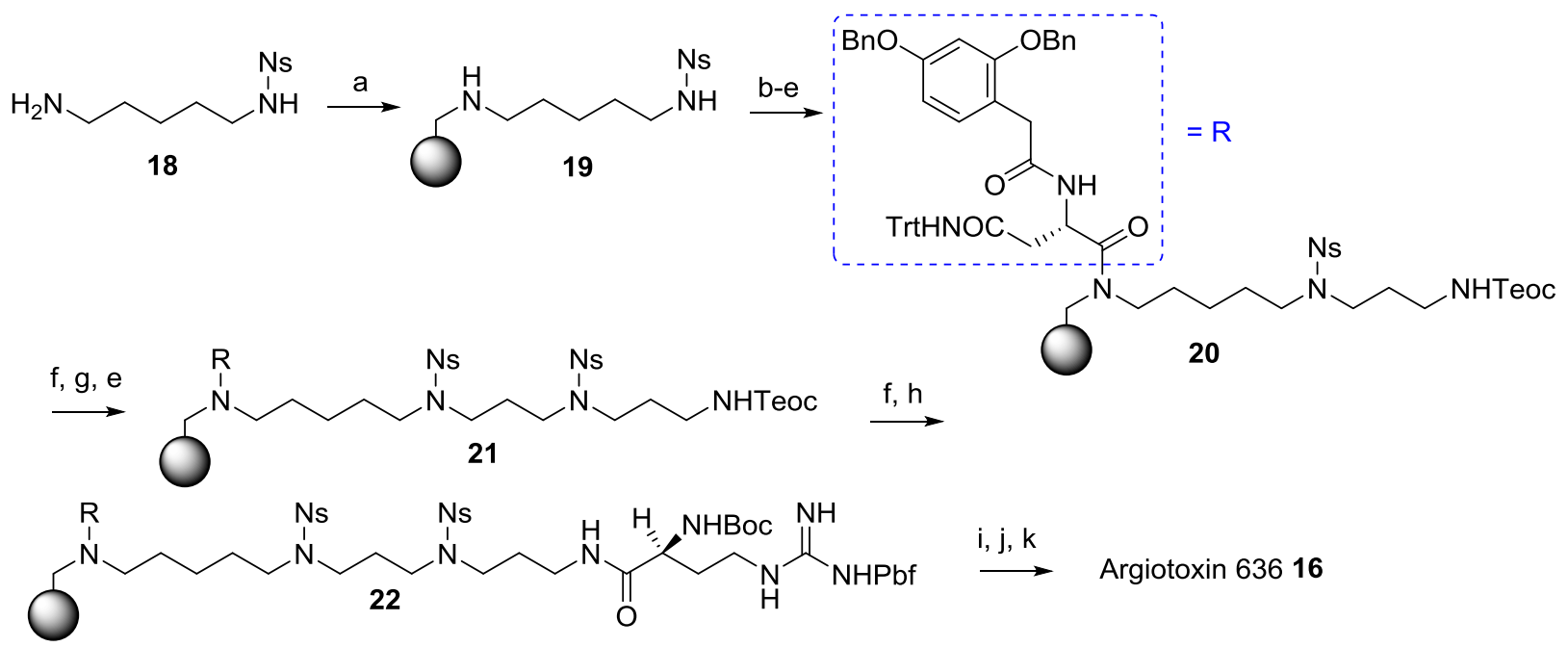

Figure 8. Solid-phase synthesis of ArgTX-636 16. Reagents and conditions: a) BAL PS resin (loading: $0.92 \mathrm{mmol} / \mathrm{g}$ ), $\mathrm{NaCNBH}_{3}, \mathrm{DMF} / \mathrm{AcOH}$ (99:1), 1h ; b) Fmoc-L-Asn(Trt)-OH, HATU, collidine, DMF, $16 \mathrm{~h}$ followed by purification/washing and a further $16 \mathrm{~h}$; c) $20 \%$ piperidine in DNF, 2min followed by purification/washing and a further $20 \mathrm{~min}$; d) 2-(2,4bis(benzyloxy)phenyl)acetic acid, HATU, collidine, DMF, $2 \mathrm{~h}$; e) $\mathrm{OH}\left(\mathrm{CH}_{2}\right)_{3} \mathrm{NHTeoc}, \mathrm{Bu}_{3} \mathrm{P}$, ADDP, $\mathrm{CH}_{2} \mathrm{Cl}_{2} / \mathrm{THF}(1: 1), 3 \times 3 \mathrm{~h}$; f) TBAF, THF, $50^{\circ} \mathrm{C}, 30 \mathrm{~min}$; g) Ns-Cl, THF/ $\mathrm{CH}_{2} \mathrm{Cl}_{2}$ (2:1), 3h ; h) Boc-L-Arg(Pbf)-OH, HATU, collidine, DMF, 2h ; i) DBU, $\beta$-mercaptoethanol, DMF, $3 \times 20$ min ; j) TFA/ $\mathrm{CH}_{2} \mathrm{Cl}_{2} / \mathrm{TIS} / \mathrm{H}_{2} \mathrm{O}$ (47.5:47.5:2.5:2.5), 2h ; k) $\mathrm{H}_{2}, \mathrm{Pd} / \mathrm{C}, \mathrm{MeOH}, 16 \mathrm{~h}$.

On a biological point of view, it was demonstrated that ArgTX-636 antagonizes a specific class of glutamate receptors and exerts actions on various types of antagonism. [28] Indeed, argiotoxin 636 is a potent but nonselective open-channel blocker of iGlu receptor with a selectivity for the NMDA receptor with respect to AMPA or KA receptor with an $\mathrm{IC}_{50}$ of 10, 77 and $300 \mathrm{nM}$, respectively. [29-31] Thus, ArgTX-636 produces a reversible blockade of excitatory transmission with a full recovery between 2 and $4 \mathrm{~h}$ and it acts on muscle flaccidity in 10/20 min, with an $\mathrm{EC}_{50}$ of 2 and $7 \mu \mathrm{g}$ for motor and sensory inhibition, respectively. [32, 33] It was enlighten that activity of ArgTX-636 is due to its longer carbon chain which may bind deeper to the ion channel region of iGlu receptors, while the secondary amino groups are important for selectivity with respect to AMPA and NMDA receptors. [28, 34] Thus, in paralysis assays ArgTX-659 17 was demonstrated to be 4-5-fold more active than ArgTX-636 16, with $\mathrm{ED}_{50}$ values ranging from $0.8 \mathrm{pmol} / \mathrm{mg}$ to $3.4 \mathrm{pmol} / \mathrm{mg}$, respectively. [24] Additionally, it is noteworthy that ArgTX-636 was found as a potent melanogenesis inhibitor 500 times higher than the reference inhibitor, kojic acid. [35] 
In 2017, two other polyamine spider toxins of similar structure bearing an aromatic head group were discovered. Thus, $\mathrm{PA}_{366} \mathbf{2 3}$ was identified in Acanthoscuria geniculata, Chilobrachyrus penang, Phlogius sp. and Psalmopoeus irminia and $\mathrm{PA}_{389} 24$ was found in Ceratogyrus darlingi and Atrax robustus (Figure 9). [4]

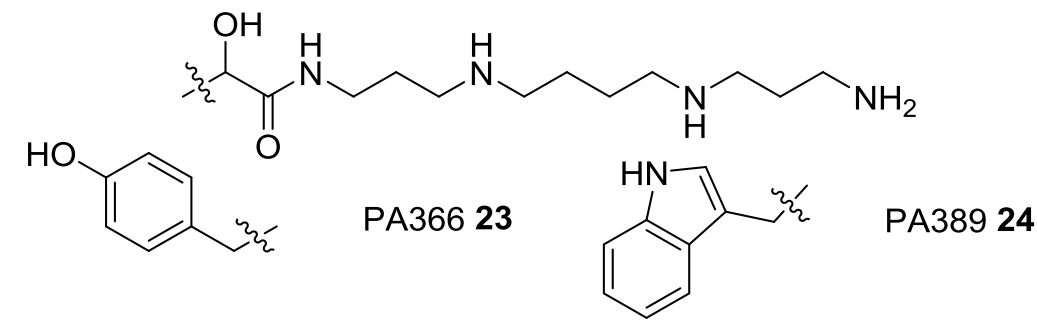

Figure 9. Structures of polyamine spider toxins $\mathrm{PA}_{366} 23$ and $\mathrm{PA}_{389} 24$.

Both polyamines are composed with a spermine tail functionalized with an aromatic head group: 2-hydroxy-3-(4-hydroxyphenyl) propanal for $\mathrm{PA}_{366}$ and 2-hydroxy-3-(1H-indol3-yl)propanal for $\mathrm{PA}_{389}$. On a biological point of view, $\mathrm{PA}_{366} 23$ and $\mathrm{PA}_{389} 24$ possess both an activity against MCF-7 breast cancer, SK-MEL-28 melanoma and neonatal foreskin fibroblast (NFF) primary cells, but $\mathrm{PA}_{366}$ is generally more active than $\mathrm{PA}_{389}$ and is selective against MCF-7 breast cancer cells. Furthermore, it was demonstrated that $\mathrm{PA}_{389}$ only displays cytotoxicity at high concentrations contrary to $\mathrm{PA}_{366}$ suggesting that the aromatic head group plays an important role for the encountered cytotoxicity. [4]

Some other polyamine spider toxins were collected and identified such as PA3343 25 and PA33433 26 in Agelenopsis aperta, PA3343 25 and PA33343 27 in Hololena curta as well as IndAc3334Gu 28 isolated from Paracoelotes birulai, with the particularity to possess a guanidino moiety (Figure 10). [36, 37]<smiles>CC(C)(C)P</smiles><smiles>NCCCNCCCNCCCCNCCCNCCCN</smiles><smiles>NCCCNCCCCNCCCNCCCNCCCN</smiles><smiles>CC(C)(C)[13CH3]</smiles>

Figure 10. Structure of linear polyamine spider toxins 25-28. 
On the other hand, another class of Nephilinae toxins were identified such as NPTX466B 29, NPTX-643F 32 from $N$. clavata, $N$. madagascariensis, $N$. cruentata and $N$. borbonica, NPTX-489B 31 collected in all Nephilinae spiders except $N$. clavata and NPTX473B 30 encountered in N. cruentata and N. borbonica (Figure ). [38]<smiles>[R7]CC(C)C(=O)C(C)CCCNC(=N)N</smiles>

Figure 11. Chemical structures of polyamine toxins from Nephilinae spiders.

Thus, a synthetic pathway was proposed to achieve the preparation of NPTX-473B 30 in 6 steps with an overall yield of $45 \%$ and involving a 2-nitrobenzenesulfonamide (Ns) group as both protecting and activating group (Figure 5). [39] First, the intermediate 34 was obtained from the coupling of the mono-Ns-putrescine 33 with $\mathrm{N}-{ }^{t}$ Boc-L-asparagine $p$-nitrophenyl ester. Then, the intermediate $\mathbf{3 6}$ was achieved from the mono-Ns-1,3-diaminopropane $\mathbf{3 5}$ by the $\mathrm{Cbz}$ protection. Finally, intermediates $\mathbf{3 4}$ and $\mathbf{3 6}$ were coupled to afford the desired polyamine backbone 37 which was subsequently deprotected and condensed with indoleacetic acid N-hydroxysuccinimide ester to provide the fully protected toxin $\mathbf{3 8}$ easily deprotected to lead to the formation of NPTX-473B 30. [40]

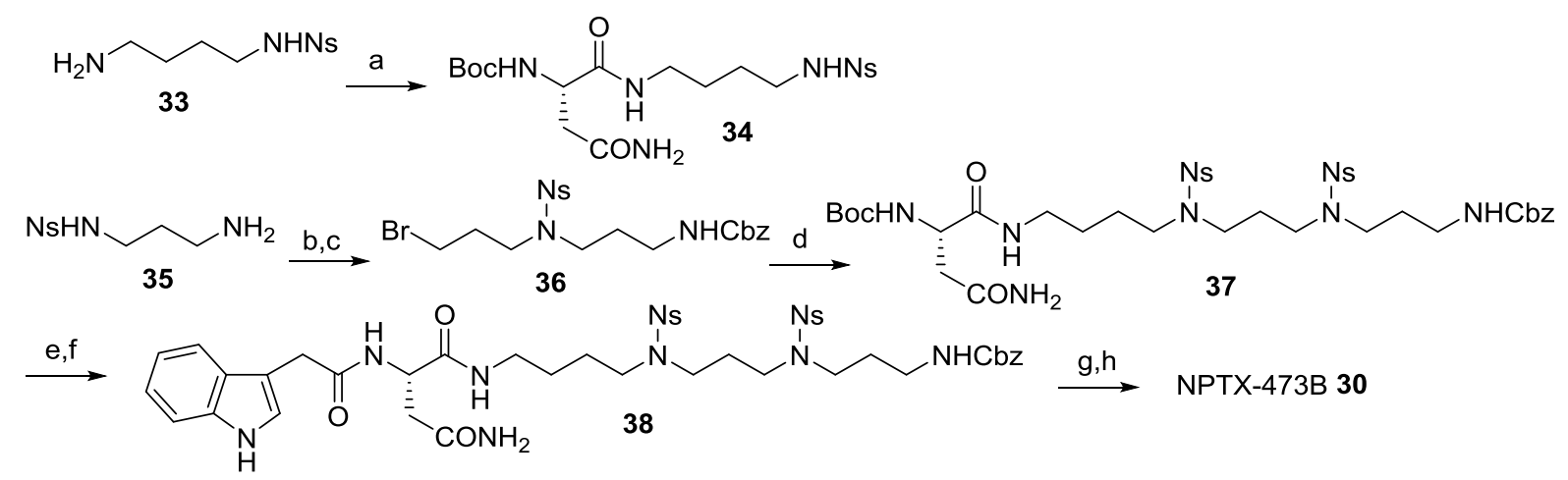

Figure 5. Synthesis of NPTX-473B 30. Reagents and conditions: (a) N-Boc-L-Asn-ONp, DMF, 95\%; (b) $\mathrm{CbzCl}, \mathrm{Et}_{3} \mathrm{~N} / \mathrm{CH}_{2} \mathrm{Cl}_{2}, 99 \%$; (c) 1,3-dibromopropane, $\mathrm{Cs}_{2} \mathrm{CO}_{3} / \mathrm{DMF}, 91 \%$; (d) 
34, $\mathrm{Cs}_{2} \mathrm{CO}_{3}$-TBAI/DMF, 94\%; (e) TFA/ $\mathrm{CHCl}_{2}$; (f) indoleacetic acid-Osu, $\mathrm{Et}_{3} \mathrm{~N} / \mathrm{DMF}, 84 \%$ (two steps); (g) 2-mercaptoethanol, DBU/DMF; (h) $\mathrm{H}_{2}$-Pd-OH)2/AcOH, 60\% (two steps).

As other polyamines previously isolated from venoms, Nephilinae toxins act as antagonists of iGlu receptors, but the particularity to containing an amino acid influence their biological activity and it was demonstrated that they can distinguish different subtypes of glutamate receptors. [38]

\section{III-2 Alpha agatoxins from spider venoms}

The study of Agelenopsis aperta, the desert grass spider belonging to the family Agelenidae in dry regions across the Southern United States and into Mexico, allows to isolate $\alpha$-agatoxins: $\mathrm{AG}_{416 \mathrm{a}}$ 39, $\mathrm{AG}_{479}$ 40, $\mathrm{AG}_{395 \mathrm{~b}}$ 41, $\mathrm{AG}_{416}$ 42, $\mathrm{AG}_{416 \mathrm{~b}}$ 43, $\mathrm{AG}_{379 \mathrm{a}} 44, \mathrm{AG}_{395 \mathrm{c}}$ 45, then $\mathrm{AG}_{488} 46$ and $\mathrm{AG}_{504} 47$ which have the particularity to bear a guanidinooxy moiety (Figure). [41-43]
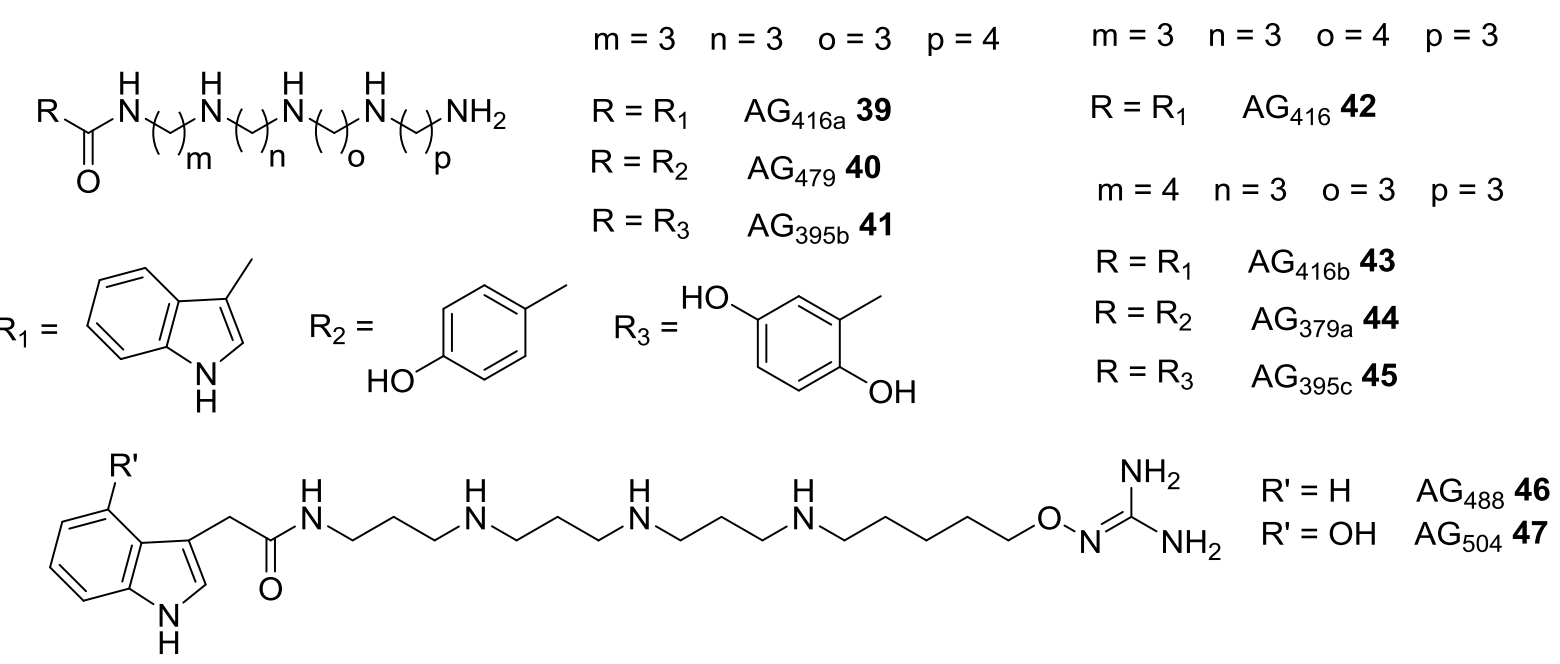

Figure 13. Structures of polyamines 39-47 isolated from the venom the A. aperta.

Chemical syntheses of $\alpha$-agatoxins 39 to $\mathbf{4 5}$ were described by Manov et al. by using a solid-phase protocol, as described in Figure 6 for the synthesis of $\mathrm{AG}_{416}$ 42. [43] Firstly, Merrifield resin was converted to intermediate $\mathbf{4 8}$, followed by an elongation of the polyamine backbone to afford intermediate 50. This latter was deprotected and the acylation with TBSIndAcOH provided the intermediate 51. Finally, the desired product was obtained by removal of $\mathbf{5 1}$ from the resin with ACE-Cl followed by $\mathrm{MeOH} / \mathrm{N}_{2} \mathrm{H}_{4} \cdot \mathrm{H}_{2} \mathrm{O}$ (Figure 14). [43] It is noteworthy that Kan et al. described a synthesis of $A_{416 b} \mathbf{4 3}$ according to the Ns- 
strategy.

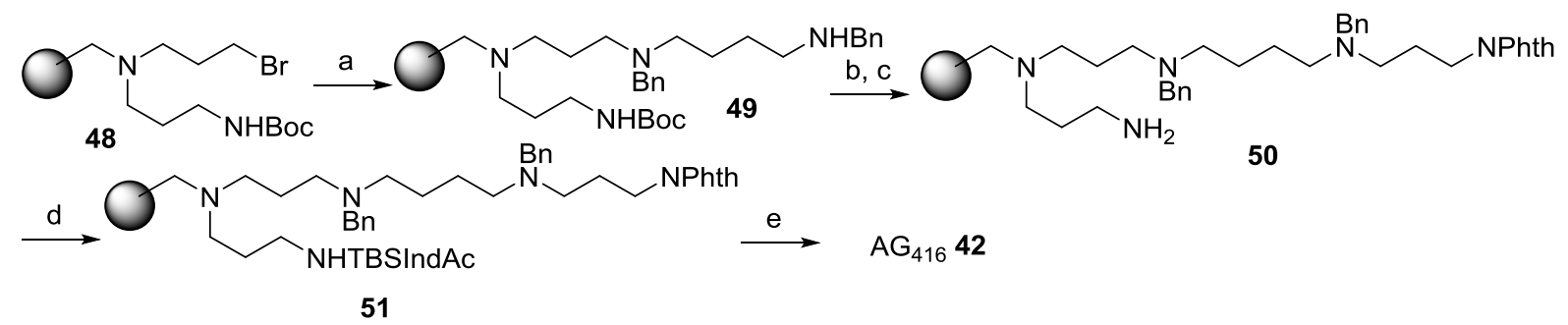

Figure 6. Synthesis of $\mathrm{AG}_{416}$ 42. Reagents and conditions: (a) NMP, N,N'-Dibenzylbutane1,4-diamine, DIEA; (b) NMP, N-(3-Bromopropyl)phthalimide, DIEA; (c) TFA, $\mathrm{CH}_{2} \mathrm{Cl}_{2}$; (d) AcylOH, DIC, NMP / $\mathrm{CH}_{2} \mathrm{Cl}_{2}, 2-\{1$-(tert-butyl)dimethylsilyl]-1H-indole-3-acetic acid; (e) ACE-Cl, $\left(\mathrm{CH}_{2} \mathrm{Cl}_{2}\right)_{2}$ then $\mathrm{MeOH}, \mathrm{N}_{2} \mathrm{H}_{4} \cdot \mathrm{H}_{2} \mathrm{O}$

On a biological point of view, $\alpha$-agatoxins block glutamate-sensitive receptor channels in insects, as other polyamines isolated from spider venoms, but they possess the particularity to antagonize NMDA receptor specifically and potently. [42, 45] Thus, it was demonstrated that $\mathrm{AG}_{416} 42$ possesses an $\mathrm{IC}_{50}$ of $36 \mu \mathrm{M}$ to antagonize NMDA responses in the hippocampal slice preparation and $0.52 \mu \mathrm{M}$ to antagonize in NMDA the cytosolic free calcium concentrations in cerebellar granule neurons. [41] Thus, paralytic action is provided by a polyamine at least the size of spermine which is acylated with an aromatic acid. [42] Furthermore, it was demonstrated that $\alpha$-agatoxins can exert anticonvulsant effects. [41]

\section{III-3 Jorotoxins from spider venoms}

In 2011, the study of the venom of Nephila clavata allows to isolate a molecule belonging to the joro spider toxin family, namely JSTX-4 52 (Figure ). [34]<smiles>N=C(N)NCCC[C@H](N)C(=O)N[C@@H](CCCN)C(=O)NCCCCCNC(=O)[C@H](CC(N)=O)NC(=O)Cc1ccc(O)cc1O</smiles>

Joro spider toxin-4 (JSTX-4 52)

Figure 15. Chemical structure of Joro spider toxin-4 $\mathbf{5 2}$.

A chemical synthesis of JSTX-4 52 was then proposed using a solid-phase protocol closely related to that used for the synthesis of AgTX-636 16, in 10 steps with an overall yield of 39\% (Figure 7). [34] First, 2-(trimethylsilyl)ethyl 5-aminopentylcarbamate 53 was attached by a backbone amide linker on the resin through a reductive amination, then the aromatic 
headgroup was generated by subsequent couplings of protected asparagine and 2-(2,4-bis(benzyloxy)phenyl)acetic acid to provide the intermediate 54. The N-Teoc protection group was then selectively cleaved with TBAF and the appropriately protected ornithine was coupled to afford $\mathbf{5 5}$ which was subsequently deprotected and coupled with the protected arginine to achieve the fully protected, resin-bound JSTX-4 56. Subsequent cleavage by treating resin with TFA, triisopropylsilane, water and subsequent deprotection of the aromatic O-benzyl groups with $\mathrm{Ph}(\mathrm{OH})_{2} / \mathrm{C}$ and $\mathrm{H}_{2}$ in solution afford JSTX-4 52. [34]

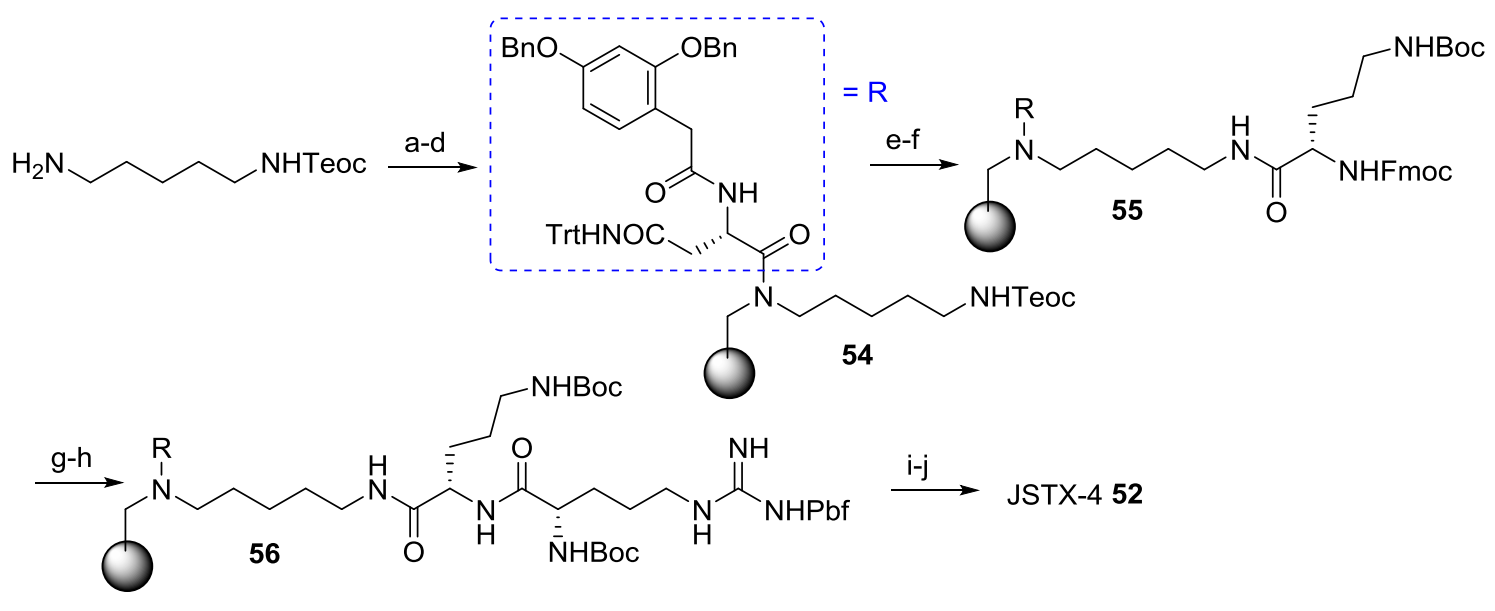

Figure 7. Synthesis of JSTX-4 52. Reagents and conditions: (a) (i) DFPE resin, DMF / acetic acid (9:1); (ii) $\mathrm{NaBH}(\mathrm{OAc})_{3}$; (b) Fmoc-L-Asn(Trt)-OH, HATU, DIPEA, $\mathrm{CH}_{2} \mathrm{Cl}_{2} /$ DMF (9:1); (c) 20\% piperidine in DMF; (d) 2-(2,4-bis(benzyloxy)phenyl)acetic acid, HATU, DIPEA, $\mathrm{CH}_{2} \mathrm{Cl}_{2} /$ DMF (9:1); (e) TBAF, THF, $55^{\circ} \mathrm{C}$; (f) Fmoc-L-Orn(Boc)-OH, HATU, DIPEA, $\mathrm{CH}_{2} \mathrm{Cl}_{2}$ / DMF (9:1); (g) 20\% piperidine in DMF; (h) Boc-L-Arg(Pbf)-OH, HATU, DIPEA, $\mathrm{CH}_{2} \mathrm{Cl}_{2} / \mathrm{DMF}$ (9:1); (i) TFA / $\mathrm{CH}_{2} \mathrm{Cl}_{2} / \mathrm{TIPS} / \mathrm{H} 2 \mathrm{O}$ (75:20:2.5:2.5); (j) $\mathrm{Pd}(\mathrm{OH})_{2} / \mathrm{C}, \mathrm{H}_{2}$, HOAC.

As other toxins isolated from spider venoms, JSTX-4 52 is an open-channel blocker of iGlu receptors, but less effective than other toxins since a $100 \mu \mathrm{M}$ concentration is required to inhibit $25 \%$ of both receptor subtypes. [34] On the other hand, contrary to other spider venoms toxins, the action of $\mathbf{5 2}$ block irreversibly the neuromuscular junction of the walking leg of lobster. [46]

\section{III-4 Philanthotoxins from European beewolf wasp}

Except for spiders, polyamine toxins were encountered in the venom of other arthropods such as Philanthus triangulum, commonly known as the european beewolf and which is a solitary wasp that lives in the Western Palearctic and Afrotropics. In 1990, a toxin 
namely Philanthotoxin-433 (PhTX-433 57) and composed by a central tyrosine, a residue amide-linker, a thermospermine moiety and an n-butanoyl chain was isolated from the venom of the female (Figure 8. Structure of philanthotoxin-433 (PhTX-433 57)Figure 8). [47-50]

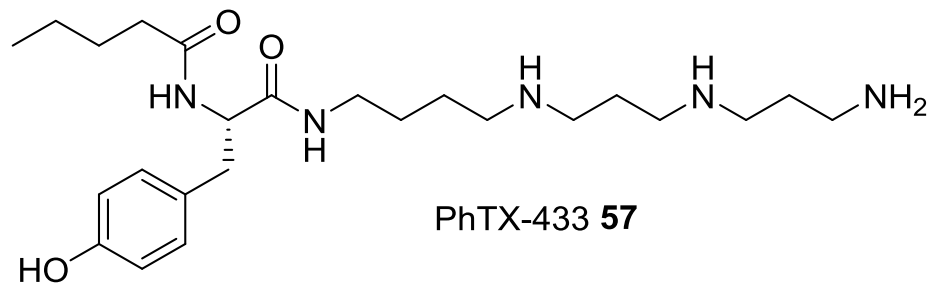

Figure 8. Structure of philanthotoxin-433 (PhTX-433 57).

Few chemical syntheses of PhTX-433 57 were described and always using a multistep solution phase strategy. [51-53] In 2000, a versatile solid-phase synthesis was purposed with $77 \%$ of yield and $80 \%$ of purity (Figure 9). [54] Starting from the resin 58, two successive amides coupling and deprotection steps afforded the $\beta$ Ala- $\gamma$ Abu-diamide 59. The reduction of 59, followed by an oxidative workup and protection with Boc provided the intermediate $\mathbf{6 1}$ which was subsequently coupled with Fmoc-L-Tyr $\left({ }^{\mathrm{t}}-\mathrm{Bu}\right)$, treated with piperidine, and coupled with butyric acid to afford 62. Crude toxin 57 was then finally obtained as a tris(trifluoroacetate) ammonium salt after cleavage from the resin. [54] Since this first synthesis, other solid-phase syntheses were described to successfully obtain PhTX-433 57. [55-57]

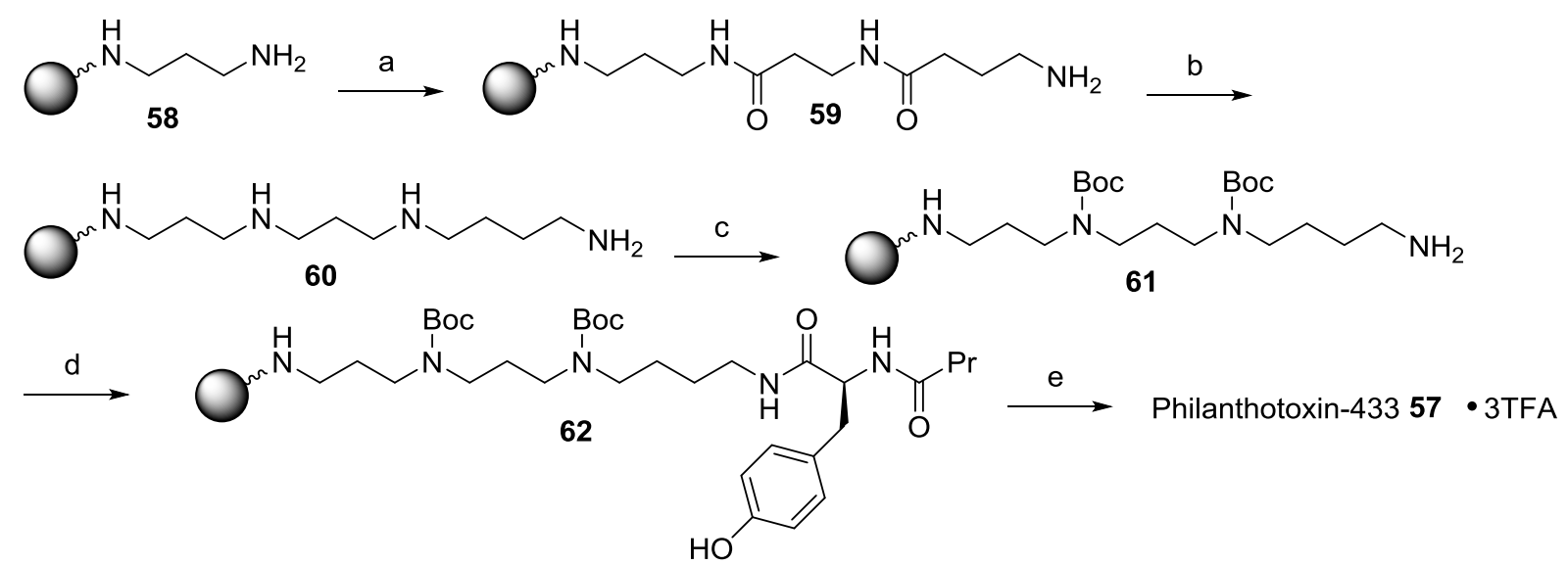

Figure 9. Synthesis of PhTX-433 57. Reagents and conditions: (a) (1) (i) $\mathrm{HO}_{2} \mathrm{C}\left(\mathrm{CH}_{2}\right)_{2} \mathrm{NHFmoc}$, HBTU, HOBt, i-Pr ${ }_{2} \mathrm{EtN}$, DMF; (ii) 20\% Piperidine / DMF; (2) Repeat step (1) with $\mathrm{HO}_{2}\left(\mathrm{CH}_{2}\right)_{3} \mathrm{NHFmoc}$; (b) (1) $1 \mathrm{M} \mathrm{BH}_{3} / \mathrm{THF}$; (2) Iodine, THF / i-Pr ${ }_{2} \mathrm{EtN} / \mathrm{AcOH}$ (7 : $1:$ 2); (c) (1) 2-Ac-dimedone, DMF; (2) $\mathrm{Boc}_{2} \mathrm{O}$, i- $\mathrm{Pr}_{2} \mathrm{EtN}, \mathrm{CH}_{2} \mathrm{Cl}_{2}$; (3) $2 \% \mathrm{NH}_{2} \mathrm{NH}_{2} /$ DMF; (d) (1) (i) HO-Tyr( $\left.{ }^{\mathrm{t}}-\mathrm{Bu}\right)-\mathrm{Fmoc}, \mathrm{HBTU}, \mathrm{HOBt}$, i-Pr. $\mathrm{EtN}, \mathrm{DMF}$; (ii) $20 \%$ Piperidine / 
DMF; (2) $\mathrm{CH}_{3} \mathrm{CH}_{2} \mathrm{CH}_{2} \mathrm{CO}_{2} \mathrm{H}, \mathrm{HBTU}, \mathrm{HOBt}$, i- $\mathrm{Pr}_{2} \mathrm{EtN}$, DMF; (e) TFA / $\mathrm{H}_{2} \mathrm{O} / \mathrm{i}-\mathrm{Pr}_{3} \mathrm{SiH}$ (95 : $2.5: 2.5)$.

PhTX-433 possesses a neuromuscular activity to immediately paralyze a prey but with reversible effect. [51, 58] It was demonstrated that PhTX-433 57 is a non-selective and uncompetitive antagonist of ionotropic receptors, such as ionotropic glutamate receptors. [47, 52, 59] Thus, the major difference with spider venoms is that PhTX-433 also antagonizes nicotinic acetylcholine receptors (nACh) (Figure 10A). [56, 60] Furthermore, PhTX-433 has been reported to lead to a selective antagonism of quisqualate, AMPA and kainate at the spinal level (Figure 10B). [61] Otherwise, wasp venom toxin can discriminate $\mathrm{Ca}^{2+}$ permeable from impermeable AMPA and kainate receptors subtypes. [34, 62] Moreover, it was demonstrated that PhTX-433 possesses also modulatory effects on nucleotides and proteins. [56]

\begin{tabular}{|c|c|c|c|c|c|}
\hline Antagonist & $\begin{array}{c}\text { nACh } \\
\text { receptor }\end{array}$ & $\begin{array}{c}\text { qGlu } \\
\text { receptors }\end{array}$ & $\begin{array}{c}\text { Neurally-evoked twich } \\
\text { contraction of the locust }\end{array}$ & Muscles \\
\hline $\mathbf{A}$ & 1.1 & 18 & 18 & 30 \\
\hline $\mathbf{I} \mathbf{C}_{\mathbf{5 0}}(\boldsymbol{\mu} \mathrm{M})$ & $\mathrm{A}$ & & & \\
\hline & Receptors & NMDA & Quisqualate & AMPA & Kainate \\
\hline $\begin{array}{c}\text { Percentage } \\
\text { reduction (\%) }\end{array}$ & $3 \pm 2$ & $85 \pm 4$ & $87 \pm 4$ & $96 \pm 4$ \\
\hline
\end{tabular}

Figure 10. (A) $\mathrm{IC}_{50}$ values $(\mu \mathrm{M})$ for each antagonist effects of PhTX-433. (B) Table of reduction of excitatory amino acids responses of spinal neurons.

In addition, PhTX-433 possesses an activity against bacteria, by inhibiting the cationselective porins $\mathrm{OmpF}$ channels of $E$. coli by multiples binding sites with polyamines with a half-maximum inhibition for a $200 \mathrm{nM}$ concentration. [63]

Among all the philanthotoxins PhTX-433 is not the most active and some derivatives are now under current investigation to improve their activities for the development of a potent therapeutic use. [47-50, 57-59, 61, 64-69]

\section{IV-Polyamines from the sea}

IV-1 Polyamines from sharks 
Polyamines are also present in other animals than arthropods, with different chemical structures and biological activities. Thus, sharks which are predatory scavengers present remarkable resistance to bacterial and viral infections. The research of host defense agents from the dogfish shark Squalus acanthias and later from the bacterially challenged sea lamprey Petromyzon marinus, resulted in the discovery, isolation and characterization of a family of novel aminosterol derivatives (Figure 11). [70, 71] These compounds possess an invariant steroid skeleton with a trans $\mathrm{AB}$ ring junction, a polyamine attached equatorially at C-3 and a cholestane-related side chain functionalized. Squalamine $\mathbf{7 0}$ is the most abundant aminosterol found in the dogfish shark liver (10-20 $\mu \mathrm{g} / \mathrm{g})$ whereas seven other compounds (63-69) are present in smaller amounts. [70]

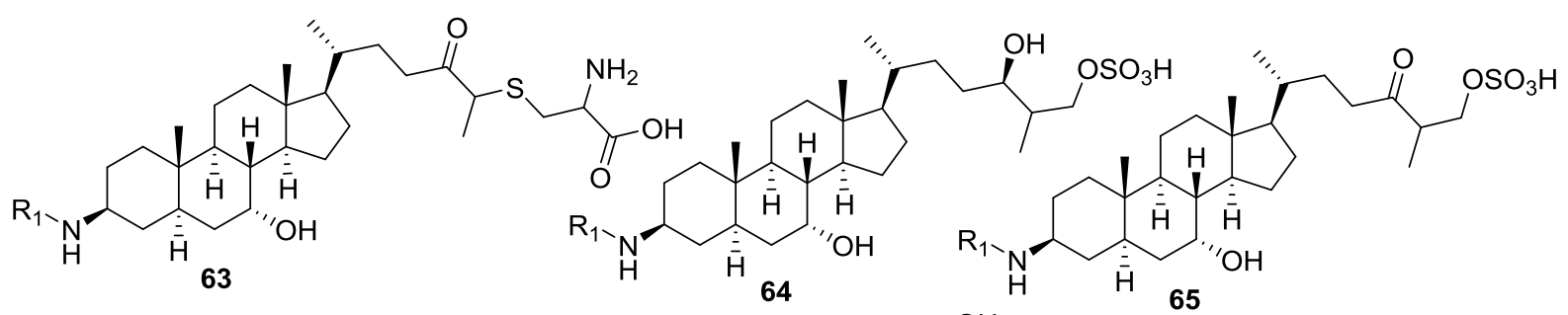

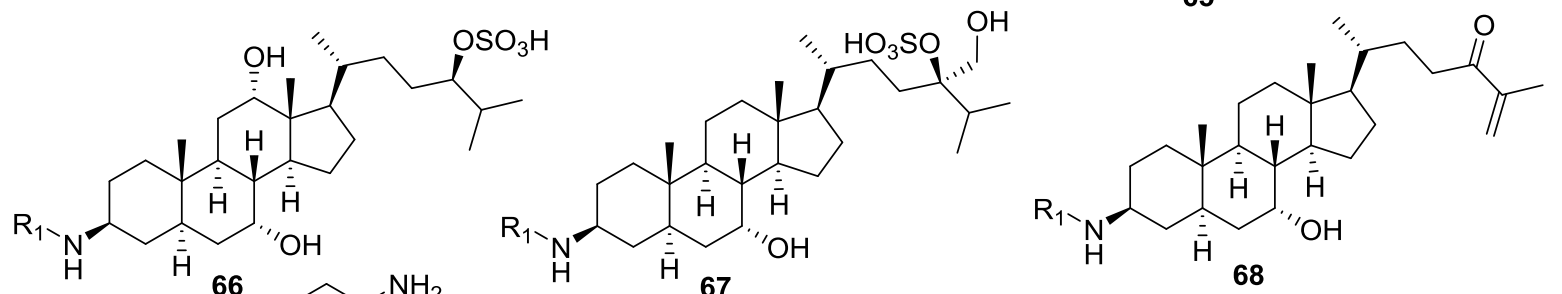

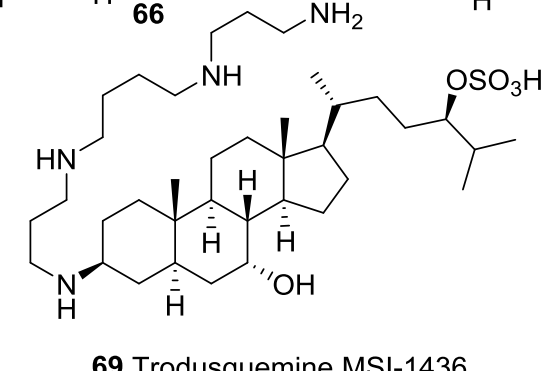

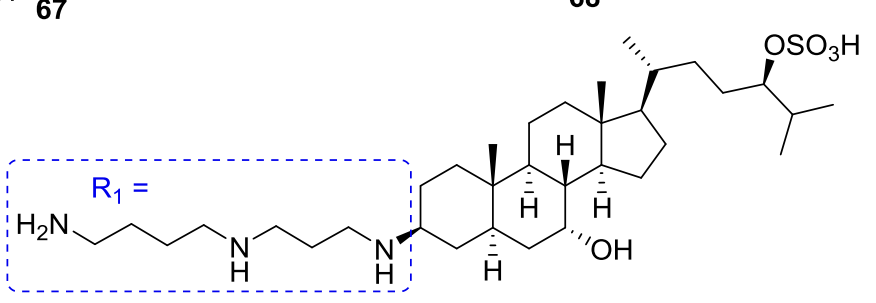

69 Trodusquemine MSI-1436

70 Squalamine MSI-1256

Figure 11. Structure of the different aminosterols 63-70 isolated from the dogfish shark liver.

\section{IV-1-1 Squalamine}

The most studied aminosterol is amphiphilic cationic steroid squalamine (Sq) 70, also called MSI-1256, provided by the white blood cells and possessing a hydrophilic head (polyamine) and a hydrophobic tail (Figure 12). [71-74] 


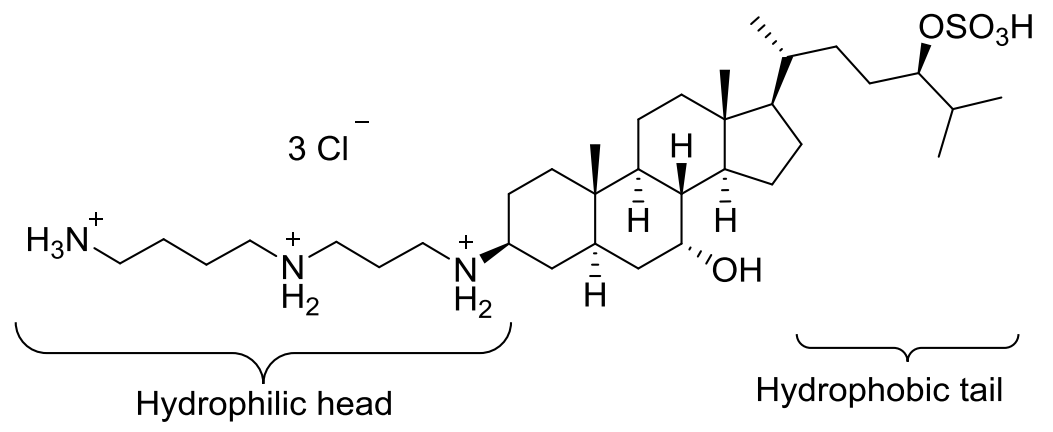

70 Squalamine $\mathrm{MSI}-1256$

Figure 12. Chemical structure of squalamine $\mathbf{7 0 .}$

During the last decades, numerous chemical syntheses were developed to achieve the preparation of squalamine $\mathbf{7 0}$ in suitable amounts (Figure 13). Both first syntheses achieved a mixture of diastereomers in C-24 position, in 17 steps. [75, 76]. In 1995, Moriarty et al. described the first stereoselective synthesis in 20 steps from stigmasterol 73. [77] The same starting material was also used by Zhang et al. who improved the synthesis in 15 steps [78], with a key intermediate $7 \alpha$-(benzoyloxy)-3-dioxolane cholestan-24(R)-ol prepared in 10 steps. [79] Another strategy based on a biotransformation, allows the researchers to reduce the synthesis to 11 steps. [80] In 2000, a synthetic pathway in 14 steps (19\% of overall yield) was developed from methyl-3-keto-5 $\alpha$-chenodeoxycholanate 75 [81] and this synthesis was subsequently improved in 9 steps with an overall yield of $31 \%$ and $99 \%$ of diastereoselectivity. [82] It is noteworthy that at the same time, a 13 steps synthesis from desmosterol 76 was reported with a 7\% overall yield. [83] Zhang and Zhou improved consecutively their previous work with a 9 steps synthesis and an overall yield of $14 \%$, starting from the easily available methyl chenodeoxycholanate 77. [84, 85] Finally, in 2019 Zhou et al. reported a synthesis of a key intermediate of squalamine $7 \alpha, 24 R$-dihydroxy-5 $\alpha$ cholestan-3-one starting from $\Delta^{5}-3 \beta$-hydroxycholanate 78, involving a one-pot Grignard reaction key step. [86] 


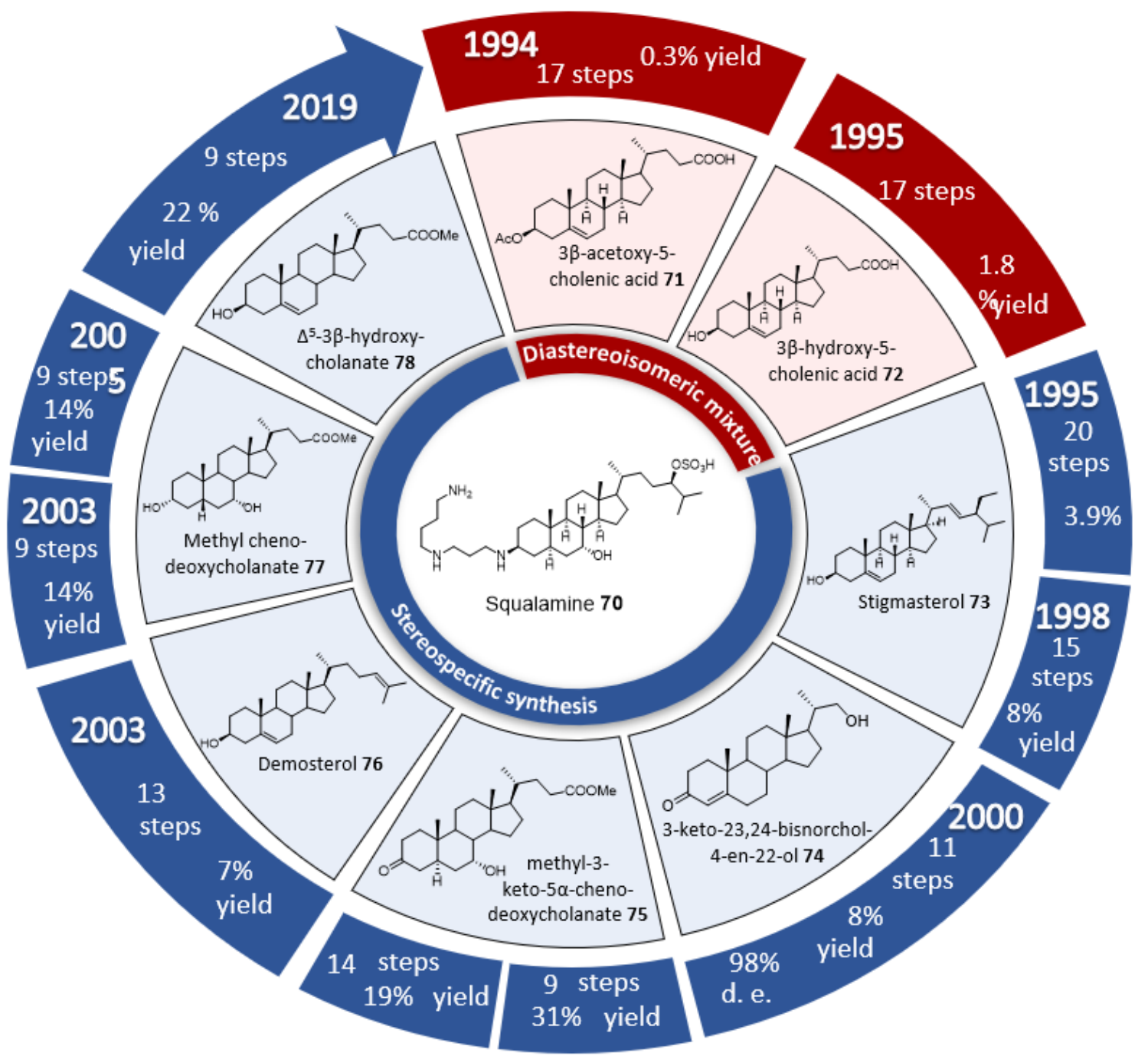

Figure 13. Different synthetic strategies reported for the preparation of squalamine $\mathbf{7 0 .}$

In this latter case, the hydroxyl function at the position C-3 was protected with THP, then a reduction of the methyl ester in position C-23 afforded the expected alcohol 79 which was protected with a benzyl moiety. The oxidation of the hydroxyl group in position C-7 lead to the intermediate $\mathbf{8 0}$ which was subsequently reduced with dihydrogen and palladium. The deprotection of the hydroxyl function in position C-3 as well as the reduction of the ketone in position C-7 afforded 82. Selective oxidation at C-3 and deprotection of the hydroxyl group in position C-24 lead to the key intermediate $\mathbf{8 3}$ which can be converted into squalamine according well-known procedures (Figure 14). [86] 


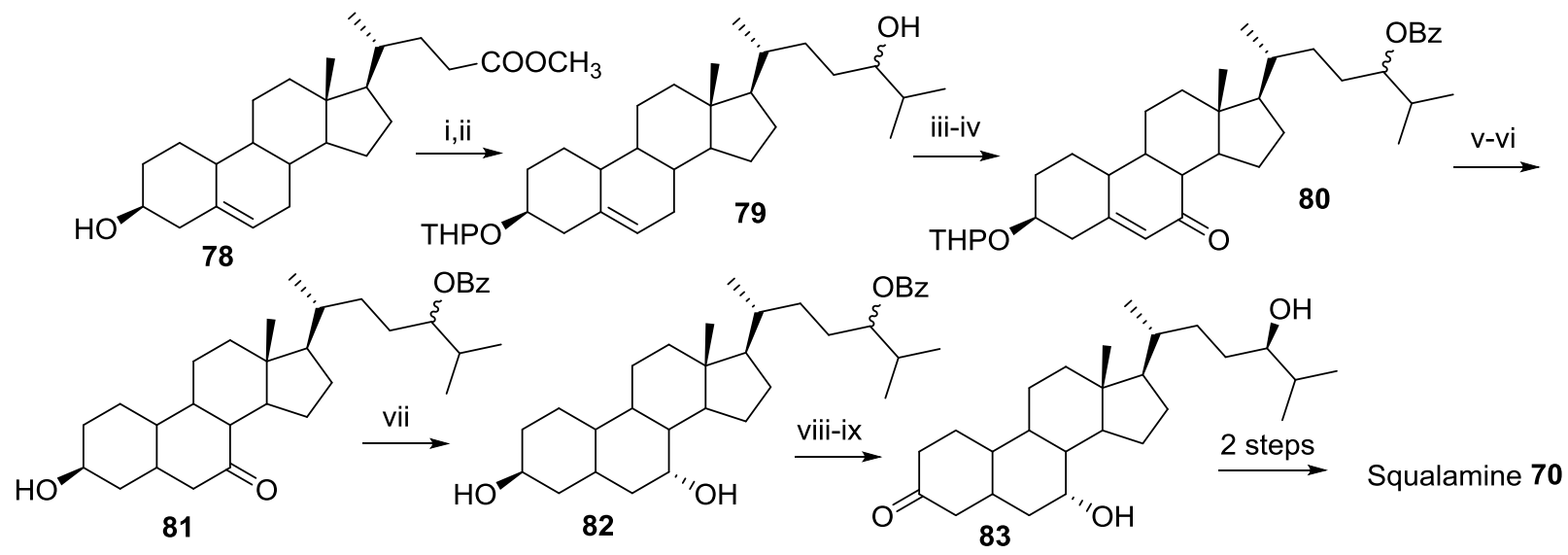

Figure 14. Synthesis of squalamine performed by Zhou et al. in 2019. Reagents and conditions: (i) DHP, PPTS, DCM; (ii) $i-P r \mathrm{MgBr}, \mathrm{LiBH}_{4}$; (iii) $\mathrm{BzCl}$; (iv) PDC, TBHP; (v) $\mathrm{H}_{2}$, $\mathrm{Pd} / \mathrm{C}$; (vi) $\mathrm{HCl}$; (vii) L-selectride; (viii) $\mathrm{AgCO}_{3} /$ Silica; (ix) $\mathrm{KOH}, \mathrm{MeOH}$

\section{IV-1-1-1 Antimicrobial activities of squalamine}

It has been demonstrated that squalamine $\mathbf{7 0}$ possesses excellent antimicrobial activities against a large panel of both Gram-positive and Gram-negative bacteria, with Minimum Inhibitory Concentrations (MICs) varying from 1 to $10 \mathrm{mg} / \mathrm{L}$ and 1 to $64 \mathrm{mg} / \mathrm{L}$, respectively (Table 1). 


\begin{tabular}{|c|c|c|c|c|c|}
\hline \multirow{3}{*}{$\begin{array}{c}\text { Gram-negative } \\
\text { bacteria }\end{array}$} & \multicolumn{3}{|c|}{ MICs (mg/L) } & \multirow{3}{*}{$\begin{array}{c}\text { Gram-positive } \\
\text { bacteria }\end{array}$} & \multirow{3}{*}{$\operatorname{MICs}(\mathrm{mg} / \mathrm{L})$} \\
\hline & \multirow{2}{*}{$\begin{array}{c}\text { Reference } \\
\text { strains }\end{array}$} & \multicolumn{2}{|c|}{ Clinical isolates } & & \\
\hline & & $\begin{array}{c}\text { Non } \\
\text { mucoid }\end{array}$ & Mucoid & & \\
\hline Escherichia coli & $1-4^{[72,87,88]}$ & $8^{[89]}$ & N.D. & $\begin{array}{c}\text { Staphylococcus } \\
\text { aureus }\end{array}$ & $1-2^{[72,87,88]}$ \\
\hline $\begin{array}{c}\text { Pseudomonas } \\
\text { aeruginosa }\end{array}$ & $4-16^{[72,87,88]}$ & $2-8^{[89]}$ & $16-32^{[89]}$ & Enterococcus hirae & $10^{[90]}$ \\
\hline $\begin{array}{c}\text { Enterobacter } \\
\text { aerogenes }\end{array}$ & $32^{[87]}$ & N.D. & $32^{[89]}$ & $\begin{array}{c}\text { Enterococcus } \\
\text { faecalis }\end{array}$ & $1-2^{[74]}$ \\
\hline $\begin{array}{c}\text { Acinetobacter } \\
\text { baumannii }\end{array}$ & $8^{[87]}$ & $8^{[89]}$ & N.D. & Fungi species & MICs (mg/L) \\
\hline $\begin{array}{c}\text { Klebsiella } \\
\text { pneumoniae }\end{array}$ & $8^{[87]}$ & $16^{[89]}$ & N.D. & Trichophyton & $8-16^{[91]}$ \\
\hline $\begin{array}{c}\text { Burkholderia } \\
\text { cepacia }\end{array}$ & $16-64^{[87]}$ & N.D. & $16-64^{[89]}$ & Candida & $\begin{array}{c}4-16^{[72,87,88,90} \\
92]\end{array}$ \\
\hline Proteus vulgaris & $4-8^{[72]}$ & N.D. & N.D. & Aspergillus & $8-16^{[88,92]}$ \\
\hline
\end{tabular}

Table 1. MICs values of Sq in $\mathrm{mg} / \mathrm{L}$ against Gram-positive and Gram-negative bacteria (from reference and clinical strains as well as from mucoid and non-mucoid clinical isolates) and against fungi. N.D.: not determined.

A time-kill study performed at the MIC demonstrated that squalamine $\mathbf{7 0}$ can kill, with a direct bactericidal effect, $S$. aureus and $P$. aeruginosa in 1 and $2 \mathrm{~h}$, respectively (Figure 15). [93]

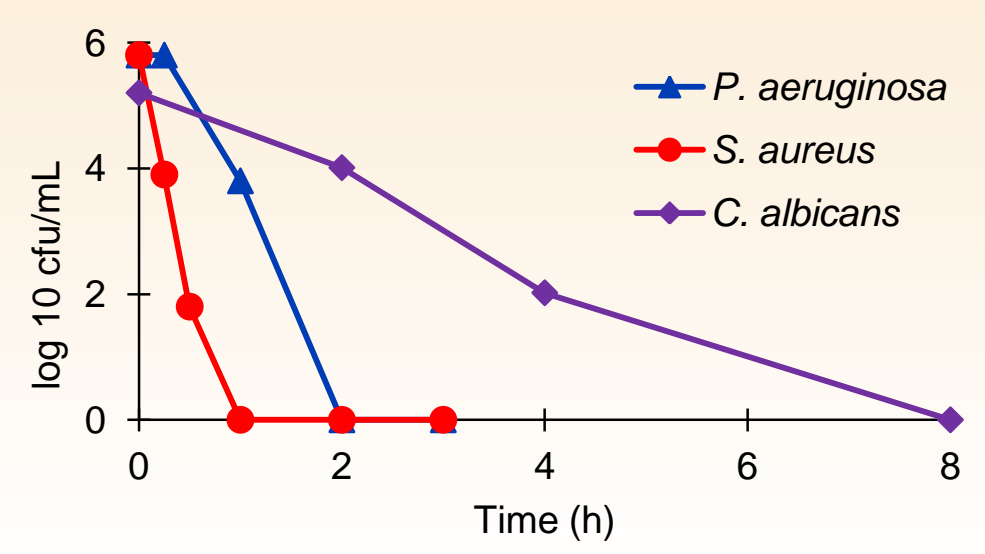

Figure 15. Time-kill curves of squalamine at the MIC against $P$. aeruginosa ATCC 27853, $S$. aureus ATCC 25923 and Candida albicans ATCC 90028. 
On a mechanistic point of view, it has been well established that squalamine induces the leakage of polar fluorescent dyes from large unilamellar phospholipid vesicles, but do not present any ionophoric activity. [94, 95] The addition of divalent cations $\left(\mathrm{Mg}^{2+}\right.$ or $\left.\mathrm{Ca}^{2+}\right)$ increased the MIC of squalamine against $P$. aeruginosa by 8 -fold

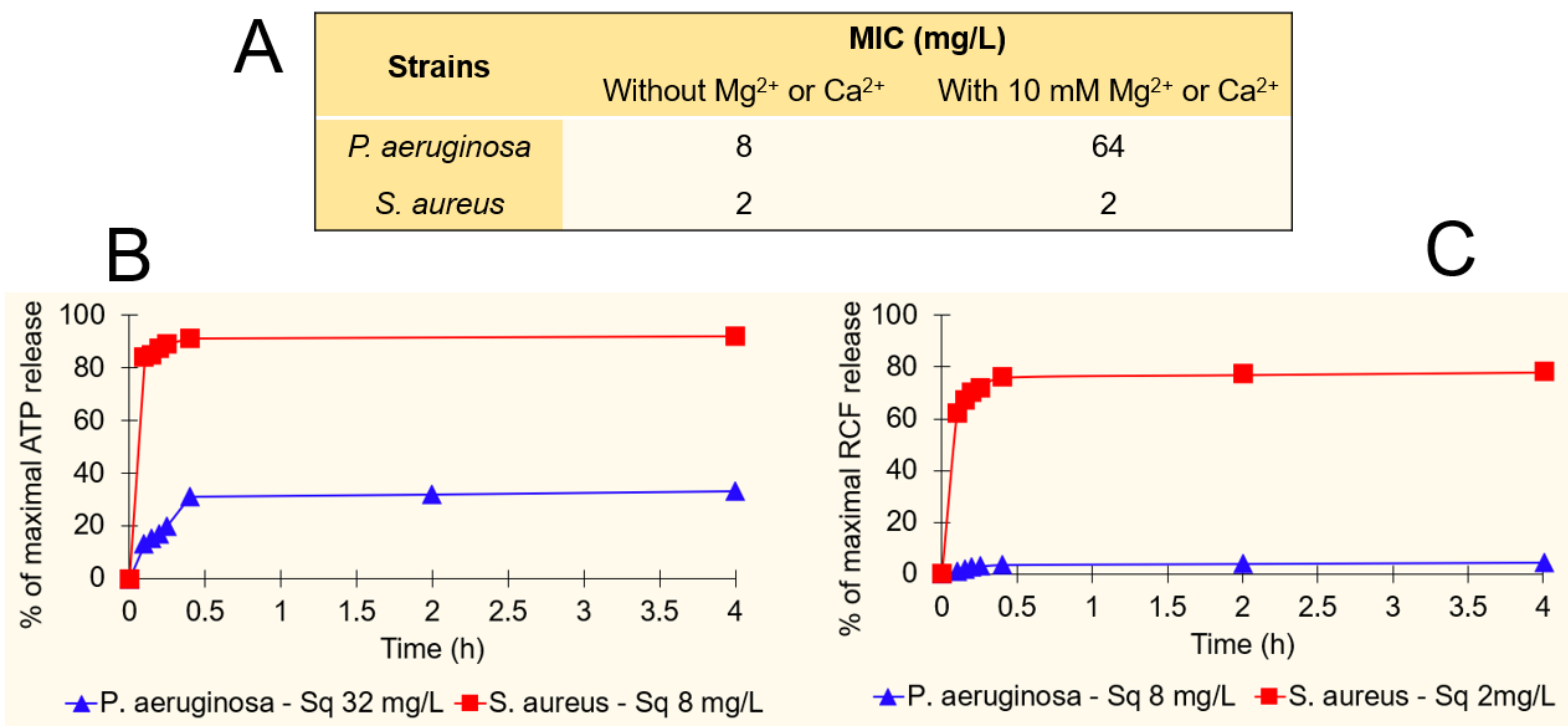

Figure 16A), suggesting that positively charged amine groups interact with negatively charged phosphate groups of lipopolysaccharides and displace divalent cations. [93] Nevertheless, this observation is only valid for Gram-negative bacteria. Furthermore, a timedependent ATP release was observed for P. aeruginosa and a rapid ATP release was induced on S. aureus, indicating that membrane lesions appear rapidly (

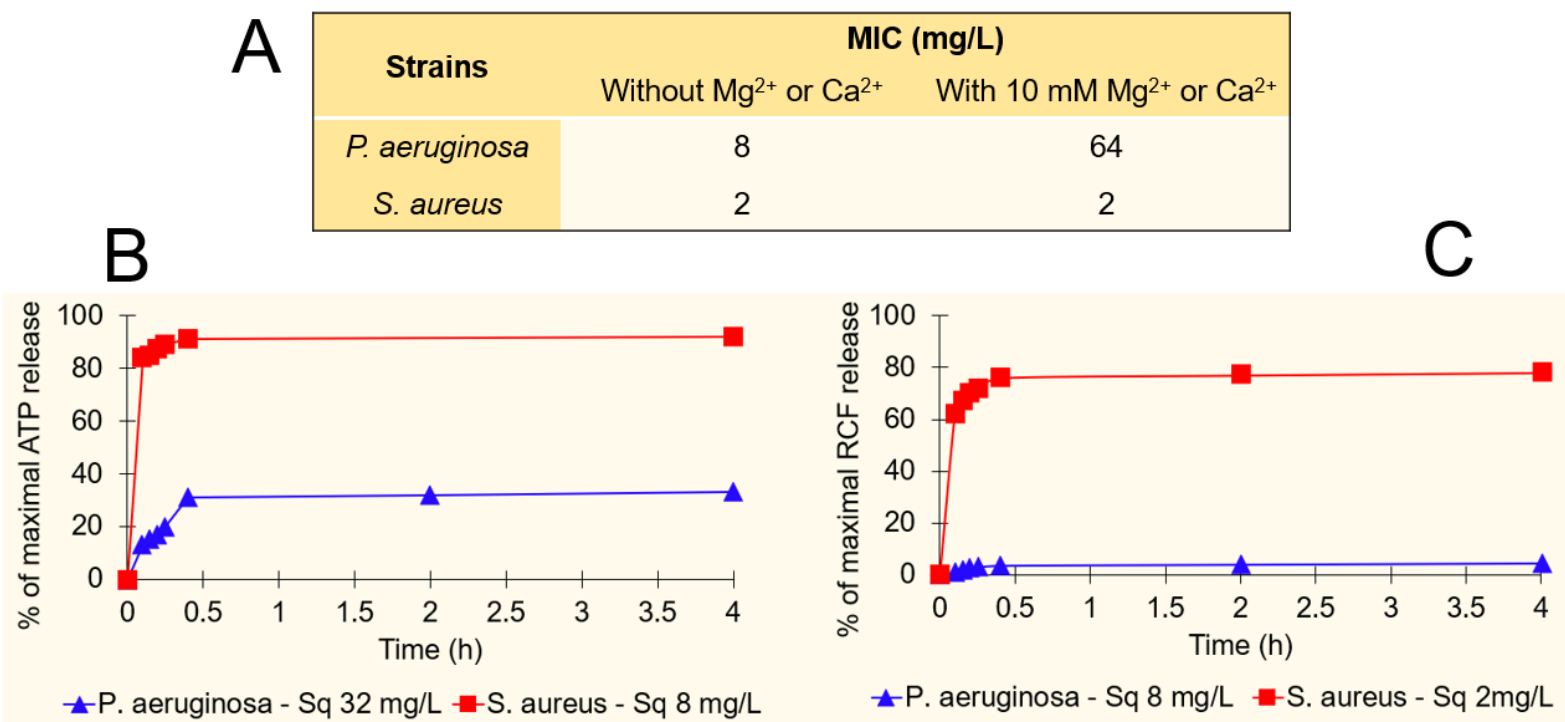

Figure 16B). [93] Finally, a strong depolarization of the Gram-positive bacterial membrane was observed with a rapid and important increased of the RCF values, whereas no depolarizing effect was observed for Gram-negative bacteria 


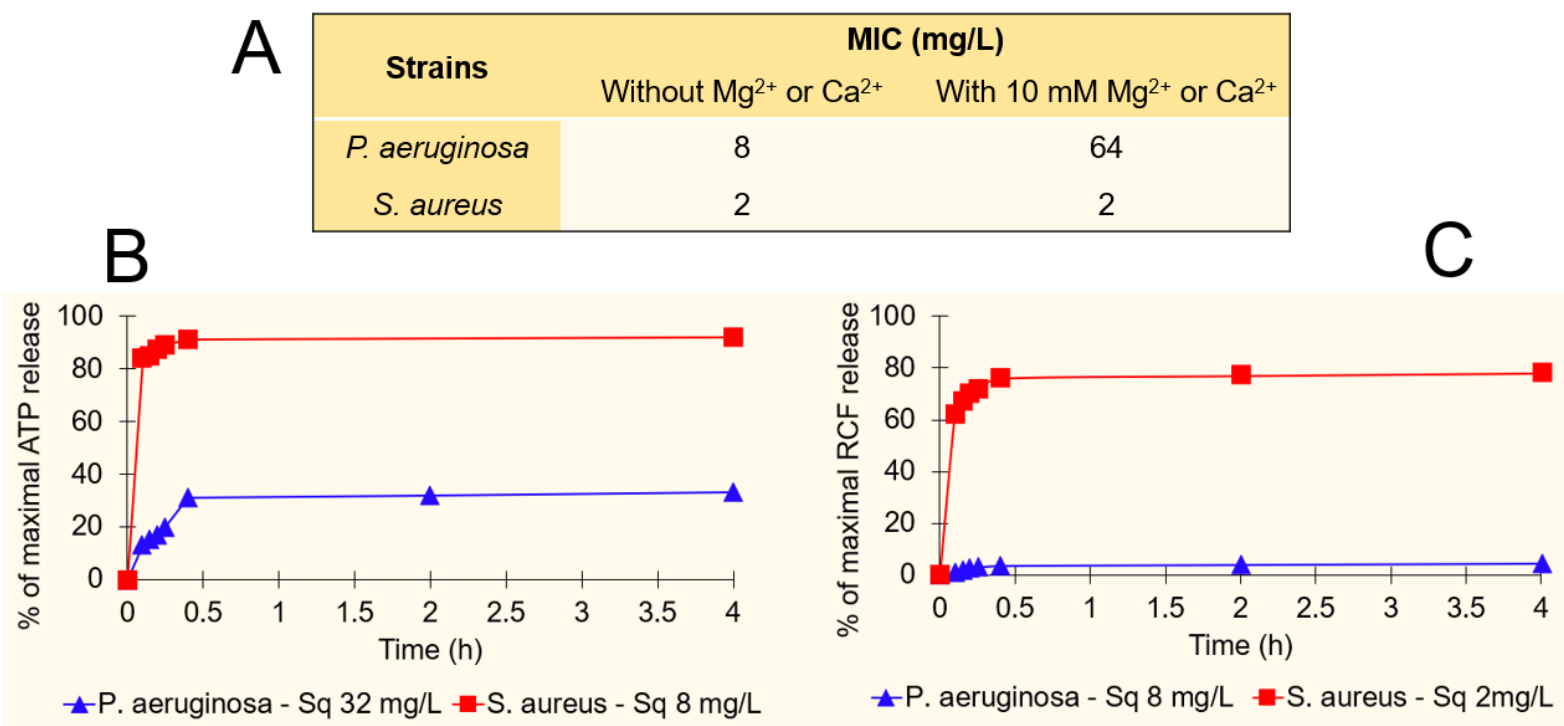

Figure 16C). [93]

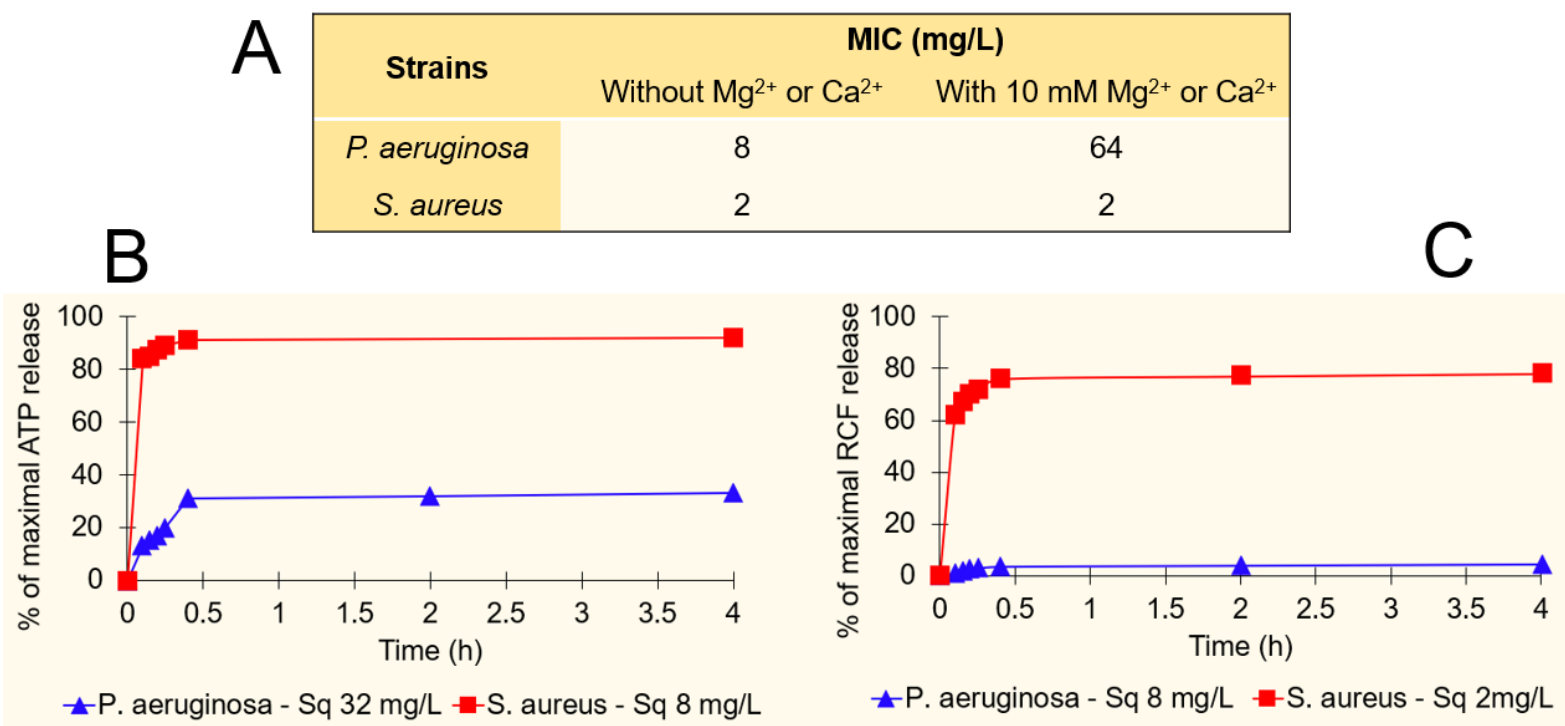

Figure 16. (A) Antimicrobial activity of $\mathrm{Sq}$ in the presence or absence of divalent cation salt solution, (B) ATP release kinetics and (C) depolarization of the bacterial membranes of Gram-positive and Gram-negative bacteria.

Based on all these considerations, a mechanism of action of squalamine has been proposed both on Gram-positive and Gram-negative bacteria (Figure 17). [87, 96] On the one hand, treatment of $S$. aureus with squalamine leads to a dramatic disruption of the bacterial membrane, causing a drainage of the cytoplasmic material. [93] On the other hand, squalamine acts as a detergent against Gram-negative bacteria, resulting in bleb-like projections that originated from the outer membrane. [93] 


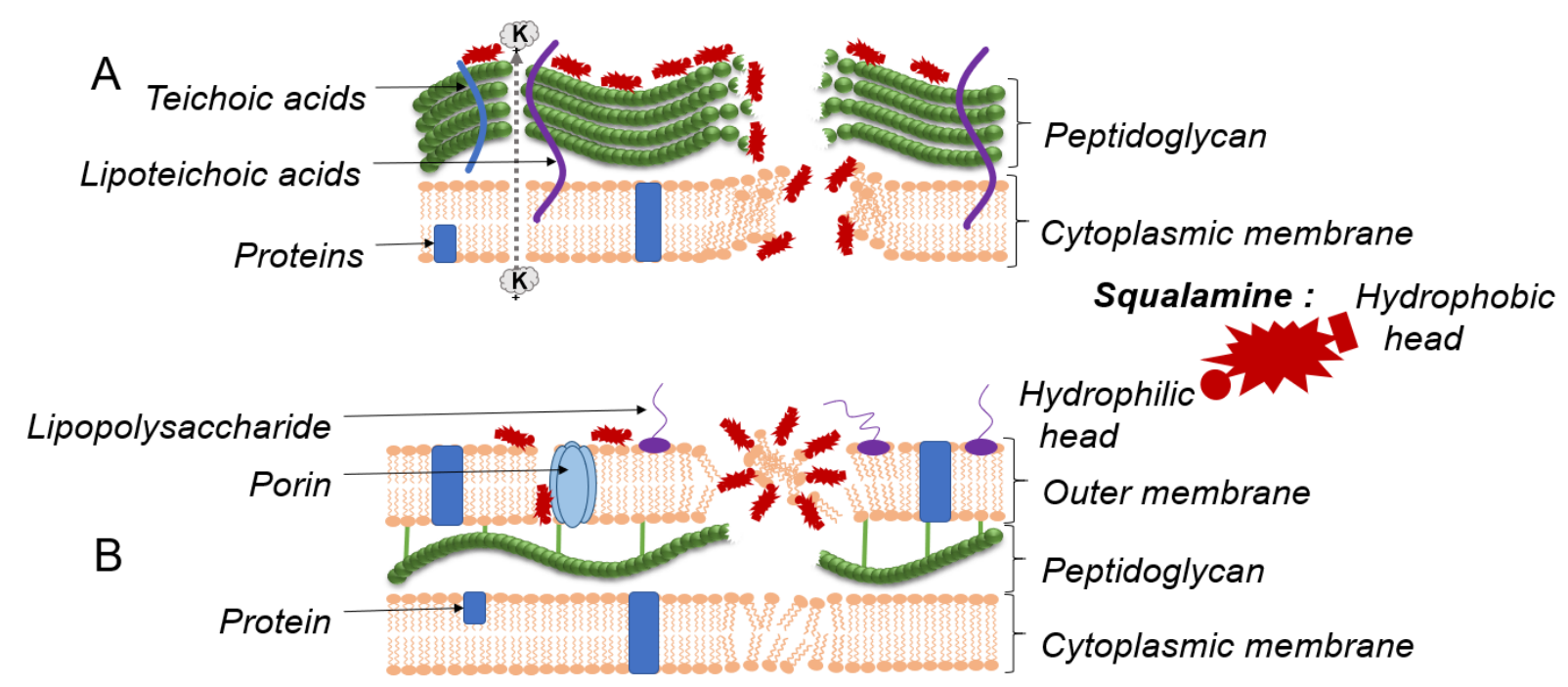

Figure 17. Mechanism of action of squalamine against (A) Gram-positive bacteria and (B) Gram-negative bacteria.

It is noteworthy that squalamine is an efficient host defense against bacteria, but some modifications can occur to protect bacteria. [97] Thus, by studying E. coli it was demonstrated that $\mathrm{O} 4$ specific antigen confers a protection against squalamine in vitro and potentiates urinary tract infection in a mouse model in vivo. In contrast the presence of the K54 antigen enhanced the antibacterial activity of squalamine. [97] It was also observed that, resistance mechanism of the bacteria becomes ineffective in presence of squalamine, because of its detergent-like mechanism of action which reduces the possibility of resistance emerging. [72, 90, 93] This was confirmed by attempts to isolate squalamine-resistant $S$. aureus strains, which failed. [98] Otherwise, squalamine was investigated against bacteria isolated from cystic fibrosis patients area (Table 1), leading of moderate to excellent MICs values varying from 2-8 $\mathrm{mg} / \mathrm{L}$ to $16-32 \mathrm{mg} / \mathrm{L}$ against non-mucoid or mucoid isolates, respectively. [89]

Additionally, squalamine was found to be able to kill dormant cells of A. baumannii without induced persisters nor viable. [99] Nevertheless, squalamine was determined to be ineffective against Mycobacterium tuberculosis certainly due to peculiar lipid composition of the membrane of this class of bacteria. $[100,101]$ On the other hand, squalamine possesses antibacterial activity against human methanogenic archaea, with MICs $\leq 1 \mathrm{mg} / \mathrm{L}$ and electron microscopy observations suggested that squalamine breaks the Methanobrevibacter smithii cell wall, inducing cytoplasm leakage and cell death, by a mechanism of action similar to that observed against Gram-negative bacteria. [102-104] 
Otherwise, squalamine was found to be used as a chemo sensitizing agent to enhance the activity of antibiotics against Gram-negative susceptible or resistant bacteria (Table 2). $[105,106]$ Thus, squalamine increases activity of chloramphenicol and ciprofloxacin against E. coli, $P$. aeruginosa and $K$. pneumoniae as well as E. aerogenes, unlike MICs of erythromycin which are not significantly improved. [105]

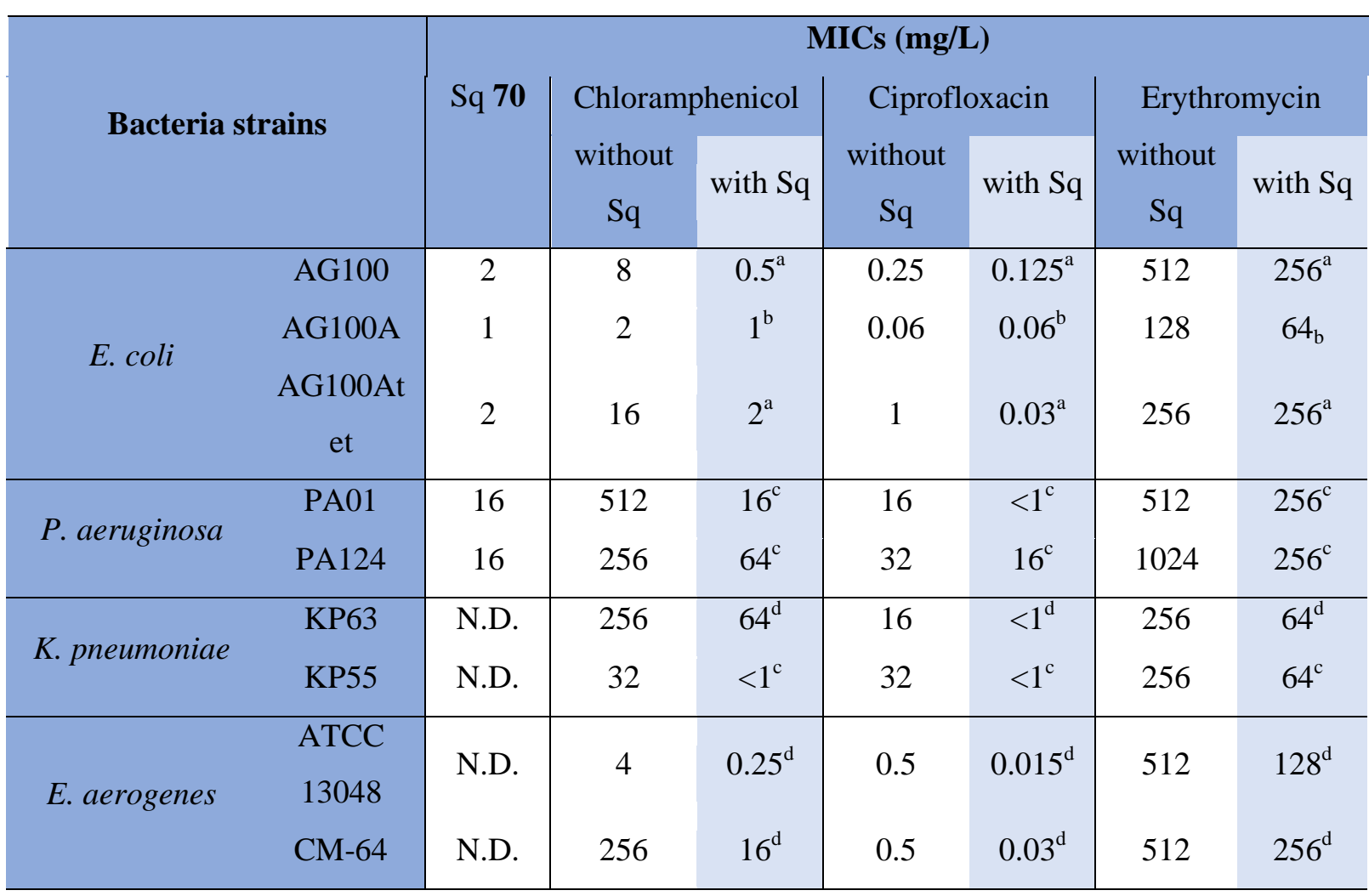

Table 2. MICs values of antibiotics in presence or absence of Sq and MICs of Sq alone against various Gram-negative bacteria. Sq concentrations: ${ }^{a} 0.4 \mathrm{mg} / \mathrm{L} .{ }^{\mathrm{b}} 0.2 \mathrm{mg} / \mathrm{L} .{ }^{\mathrm{c}} 3.2 \mathrm{mg} / \mathrm{L}$. d $1.6 \mathrm{mg} /$ L. N.D.: not determined.

As previously mentioned in Table 1, squalamine possesses a remarkable activity against a large panel of fungi with MICs ranging from 4 to $16 \mathrm{mg} / \mathrm{L}$. [91, 107] A time-kill study performed at the MIC against $C$. albicans, demonstrated a fungicidal effect observed after $8 \mathrm{~h}$ (Figure 15). [107]

Considering its antimicrobial activities against a broad spectrum of bacteria and fungi, squalamine was studied for numerous applications either in disinfection or in topic local use. First, squalamine was used as disinfecting agent for home nebulizer of cystic fibrosis patients, in form of a soluble tablet and disinfection can be achieved against both Gram-positive and Gram-negative bacteria and also fungi $C$. albicans in $20 \mathrm{~min}$, whereas $6 \mathrm{~h}$ are needed for the fungi A. niger. [108] In a second application, squalamine delivered by aerosolization was 
demonstrated to reduce, in a $P$. aeruginosa animal infected model, the lung bacterial load and bronchopneumonia-induced histological lesions with an efficiency comparable to that encountered for colistin. [109] Finally, a squalamine 1\% ointment applied in a S. aureus skin decolonization model lead to a reduction of viable bacteria by $4 \log$ in $1 \mathrm{~h}$ with a single application whereas a reduction $1.3 \mathrm{log}$ for the standard mupirocin drug was observed. [98, 110] This strategy was also envisioned, with encouraging results, in the evaluation of the ability of squalamine to act as a potent antidermatophyte drug against Miscrosporum audouinii. [111]

It is noteworthy that, these promising antimicrobial results lead to the development of efficient synthetic analogs which are not depicted here. [87, 88, 107, 112, 113]

\section{IV-1-1-2 Antiangiogenic activities of squalamine}

Cancer is the second most killing disease in the world. In this context, squalamine was demonstrated to be able to inhibit growth of few cancers thanks to its antiangiogenic activity. $[114,115]$ This effect is mediated by blocking mitogen-induced proliferation and migration of endothelial cells, thus preventing neovascularization of the tumor. [116] Nevertheless, it is noteworthy that squalamine is not directly cytotoxic for tumor cells. [116] This inhibitory effect is time dependent, with no effect after immediate addition and maximum effect with $1 \mathrm{~h}$ exposure and fully reversible. $[117,118]$ Two anti-angiogenic mechanisms were postulated: First, squalamine could selectively inhibit the sodium-hydrogen $\left(\mathrm{Na}^{+} / \mathrm{H}^{+}\right)$antiporter exchange isoform NHE3, which hinders hydrogen efflux out of the endothelial cell, and consequently blocked intracellular alkalization and cellular proliferation (Figure 18A). [117] Moreover, squalamine may alter cellular responses to growth stimuli that increase intracellular calcium by binding to NHE3 and redistributing calmodulin. [119] Secondly, squalamine could inhibit the release of the vascular endothelial growth factor (VEGF) by the tumor cell, which hinders binding and activation of VEGF receptor of the endothelial cell (Figure 18B). [120] 


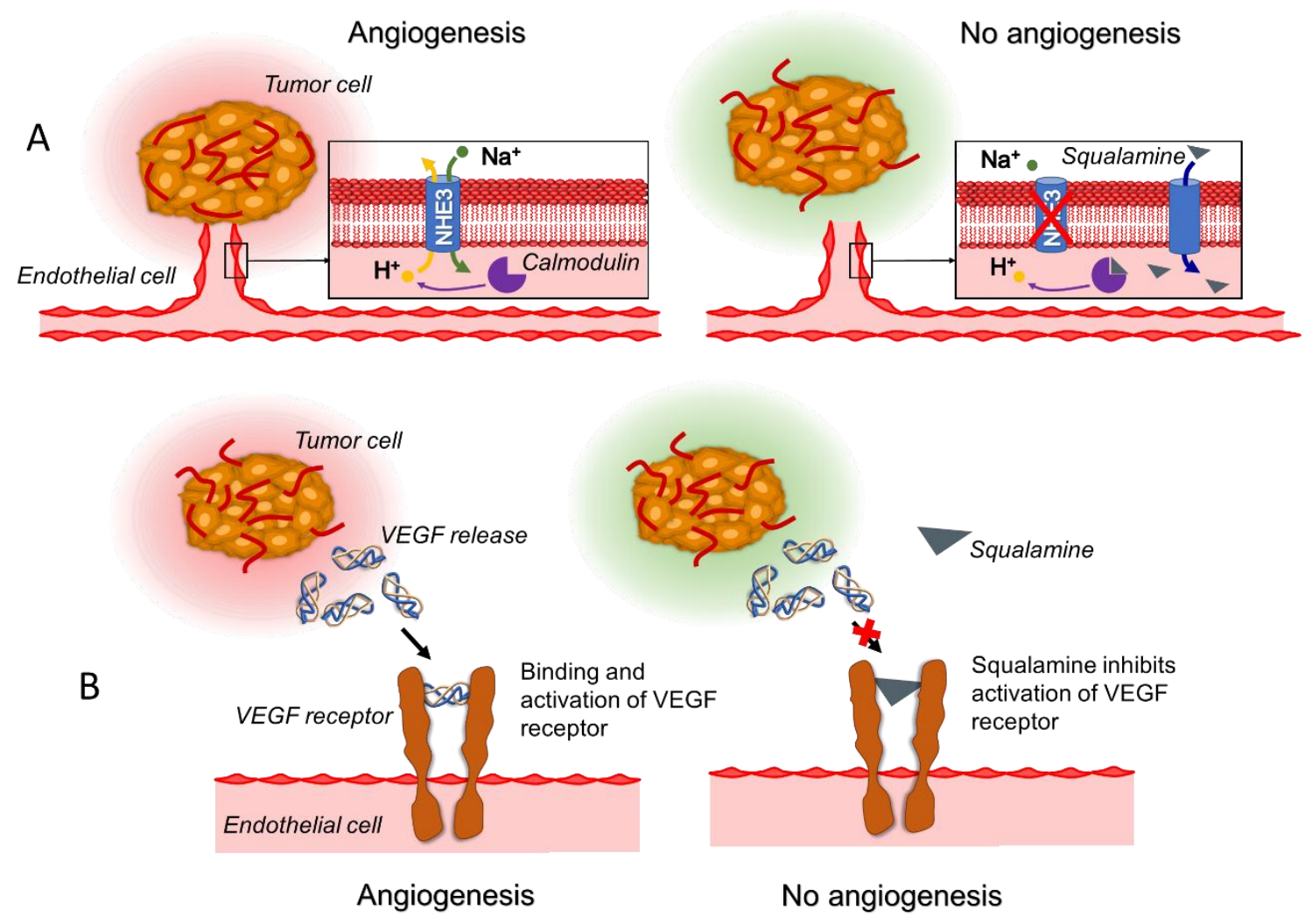

Figure 18. Potent mechanisms of anti-angiogenic activity of squalamine by inhibiting (A)

NHE3 protein and (B) VEGF receptor.

On a clinical point of view, the use of squalamine in combination with chemotherapy for the treatment of lung cancer patients was performed. [121] It appears that squalamine alone does not inhibit the tumor growth, whereas its combination with cisplatin or carboplatin is efficient against tumor cells growth and better than the platinum analogues taken alone (Table 3). [121] In this case, squalamine stops new blood vessels growth by disrupting endothelial cell architecture and the integrity of endothelial cell-cell attachment in tumors and consequently prevents further tumor growth. [115]

\begin{tabular}{c|c|cc|cc}
\hline \multicolumn{2}{c|}{} & \multicolumn{5}{|c}{ Tumor growth delays in days } \\
Tumor & \multirow{2}{*}{$\mathrm{Sq}$} & \multicolumn{2}{|c}{ Cisplatin } & \multicolumn{2}{c}{ Carboplatin } \\
\multicolumn{1}{l|}{} & & without Sq & with Sq & without Sq & with Sq \\
\hline H460 & $<0.2$ & 2.5 & $>5$ & 2.9 & $>6.7$ \\
Calu-6 & $<0.8$ & 5 & $>10.7$ & 2.5 & $>6.3$ \\
NL20T-A & $<0.1$ & 12 & $>29$ & N.D. & N.D. \\
Lewis lung & $<0.02$ & 2.1 & 3.6 & 3.1 & 5.7 \\
\hline
\end{tabular}

Table 3. Treatment of different tumors with cisplatin and carboplatin in the presence or absence of squalamine. N.D.: not determined 
It was then demonstrated that squalamine possesses an activity against prostate and breast cancer as well as neuroblastoma and lung chemoresistant tumors, alone or in combination with chemotherapy. [115, 122, 123] Furthermore, a study in ovo enlightens that squalamine has no obvious local or systemic deleterious consequences for vitality and development of the embryo. [124] Therefore, we must mention that several clinical trials were performed by using squalamine alone or in combination with chemotherapy for the treatment of various of cancers. $[115,116,119,120,125-128]$ It is noteworthy that squalamine is welltolerated by humans, thereby the US Food and Drug Administration has designated squalamine as an 'orphan drug' for development as a new antitumor agent to treat ovarian cancer, even if studies remains necessary concerning the mechanism of action induced. [127]

Age-related macular degeneration (AMD) is the leading cause of vision loss in the industrialized world. [129] In this area, it was demonstrated that squalamine blocks angiogenesis in a noncancerous model, by reducing retinal neovascularization. [130] Indeed, squalamine can inhibit growth factor-mediated endothelial cell proliferation and migration, including that stimulated by VEGF (Figure 18B), at concentrations that are not toxic for endothelial cells in vitro and without affecting normal vascular development. [131] Moreover, an assay on monkey demonstrated that systemic administration could prevent and reduce iris neovascularization. [132] The formulation of squalamine was realized as lactate salt, then tested by systematically administration on rat and partially reduced choroidal neovascular membrane development. [133] Squalamine was then tested in phase I/II clinical trials for the treatment of age-related macular degeneration, with a gain of $\geq 3$ lines in $26 \%$ of case whereas the visual acuity remained stable for $74 \%$ of the patients. $[129,130,134,135]$ With the advantage to be administered intravenously, squalamine eliminated the risk of eye infection or injury. [72] The phase II clinical study was made with more than $90 \%$ of patients have stabilized or improved vision at 4 months follow up. [136, 137] The squalamine lactate was investigated by Ohr Pharmaceutical under the name of OHR-102, with a phase III trials approved by the FDA. [138] Afterwards, a phase III squalamine/ranibizumab eyes drops assay was performed but was unsuccessful. [139-141]

\section{IV-1-1-3 Antiviral activities of squalamine}

Viral infections are one of the major causes of disease worldwide. Thus, according to the WHO in one year 390 millions of person were infected by dengue virus and hepatitis B. $[142,143]$ In this context, squalamine was demonstrated to be active in vitro and in vivo against a broad spectrum of human viral pathogens, including both RNA- and DNA- 
enveloped viruses. [144] Thus, squalamine possesses an activity against dengue virus at a concentration of $100 \mathrm{mg} / \mathrm{L}$ allowing a complete inhibition of the virus, and an activity against hepatitis B virus, leading to an $84 \%$ inhibition at a concentration of $20 \mathrm{mg} / \mathrm{L}$ (Figure 19). [144]

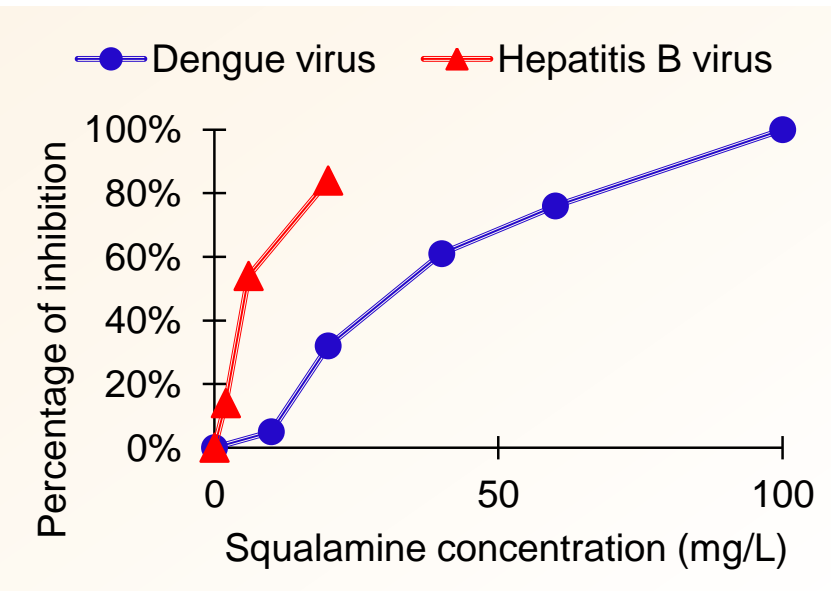

Figure 19. Effect of squalamine against dengue virus infection of human endothelial cells and hepatitis B virus infection of primary human hepatocytes.

The suggested mechanism involves the capacity of squalamine to neutralize the negative electrostatic surface charges of intracellular membranes and to bring the cell less effective in supporting viral replication, which will be detrimental to the emergence of viral resistance. [144]

\section{IV-1-1-4 Antineurodegenerative activities of squalamine}

Most common neurodegenerative disorders are Parkinson and Alzheimer, one characterized by motor dysfunction and the other is the first cause of dementia with one new patients affected every 3 seconds. [145, 146] Thus, in a preliminary study it has been demonstrated that squalamine $\mathbf{7 0}$ possesses a specific effect against $\alpha$-synuclein aggregation by acting on a competitive binding model, where squalamine and toxic $\alpha$-synuclein oligomers compete for binding sites at the surface of vesicles and neurons (Figure 20). [147-149] 

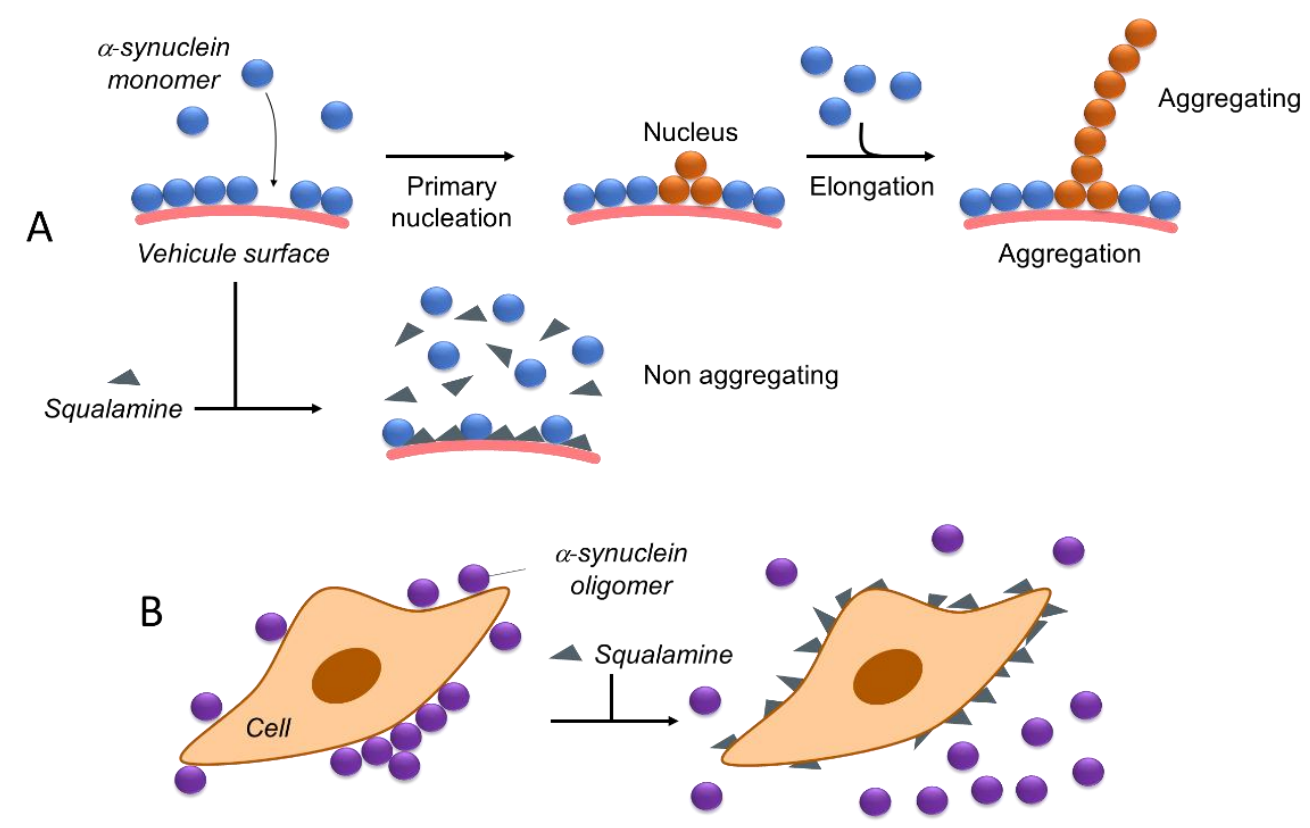

Figure 20. Effects of squalamine on a-synuclein aggregation. (A) Inhibition of the initial events of $\alpha$-synuclein aggregation. (B) Protection from toxic a-synuclein oligomers in cells via competitive binding.

\section{IV-1-1-5 Stability and cytotoxicity of squalamine}

It was demonstrated that squalamine induces blood hemolysis at $320 \mu \mathrm{M}$, which is a higher concentration than those requested to observe biological activities. [107] Squalamine was found to be non-genotoxic until at a concentration of $160 \mu \mathrm{M}$ (solubility limit), a proliferative index upper than $80 \%$ was observed. [150] Furthermore, during clinical trial a hepatotoxicity was observed, but in reversible way after discontinuation of the treatment. [130] To determine all the toxicological and pharmacokinetic parameters, a bioanalytical method for quantitative determination of squalamine in patient, as well as in animal plasma was developed. [151] Then, a study of stability of squalamine lactate in different conditions was applied, to determined eventual degradation products, and demonstrated that squalamine lactate is stable in refrigerated conditions as well as in basic solution. [152] Furthermore, the half-life of squalamine is approximately $1 \mathrm{~h}$ and terminal elimination occurs after $7.2 \mathrm{~h}$ in humans. [130] Thanks to all these studies, it is now well admitted that squalamine administration to humans is safe. [112]

\section{IV-1-2 Trodusquemine}

Trodusquemine 74 also called MSI-1436 (Figure 11), possesses the same chemical structure than squalamine $\mathbf{7 5}$, and only differs by the replacement of the spermidine moiety by 
a spermine one. This small structural difference has huge consequences on its potent biological activities.

\section{IV-1-2-1 Appetite suppressor activity}

Trodusquemine was well studied to afford reversible suppression of food and fluid intake in mammals, resulting in profound weight loss with the maintain of high-energy expenditure and on the other hand to promote insulin sensitivity and glycemic control without any symptoms of illness. [153-155] Furthermore, the intracerebroventricular administration was 1,000 times more potent than an intraperitoneal treatment, certainly since trodusquemine can cross the blood brain barrier and has a half-life of 7 days. [154]

A preliminary study suggested that trodusquemine acts on central targets by knockout the MC4 receptor. [153] It was subsequently demonstrated that trodusquemine targets the brain by inducing a Fos immunoreactivity in the paraventricular hypothalamic nucleus, but without affecting dopamine transporter function. $[154,156]$ Thus, screening assays revealed that trodusquemine inhibits protein-tyrosine phosphatase 1B (PTP1B) a key enzyme regulating insulin and leptin signaling, with an $\mathrm{IC}_{50}$ of $1.3 \mu \mathrm{M}$ in a reversible, noncompetitive and dose dependent manner (Figure 21). [155, 157-159]

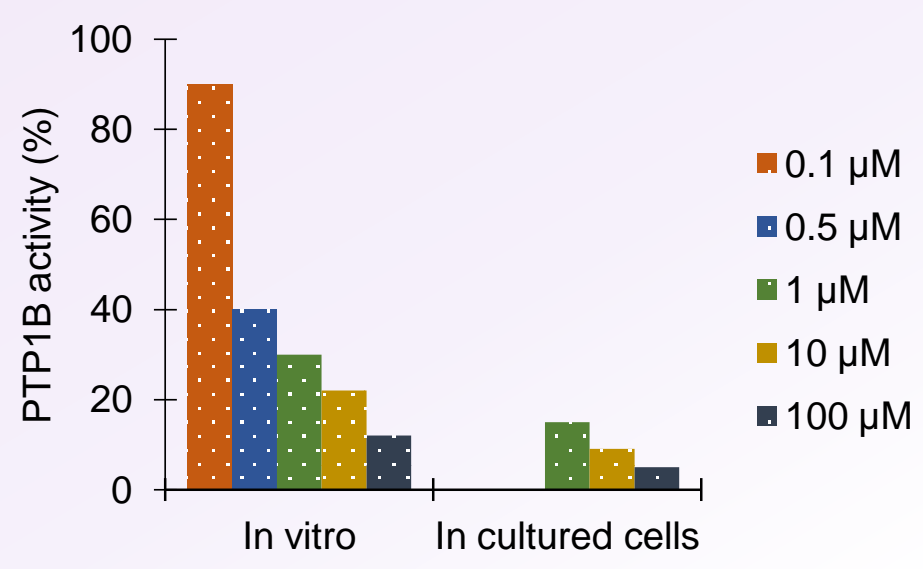

Figure 21. Inhibition activity of trodusquemine on PTP1B in vitro and in cultured cells.

A study identified two binding sites for trodusquemine in the long form of PTP1B. Hence, a first molecule of trodusquemine sandwiched between $\alpha 7$ and the C-terminal $\alpha 9$ ' may bring the $\alpha 7$ helix close to $\alpha 3$ and $\alpha 6$, forming the second site where another molecule of 69 would bind, which induced a conformational change in PTP1B enzyme and cause its inhibition by a cytostatic effect (Figure 22). [160] 


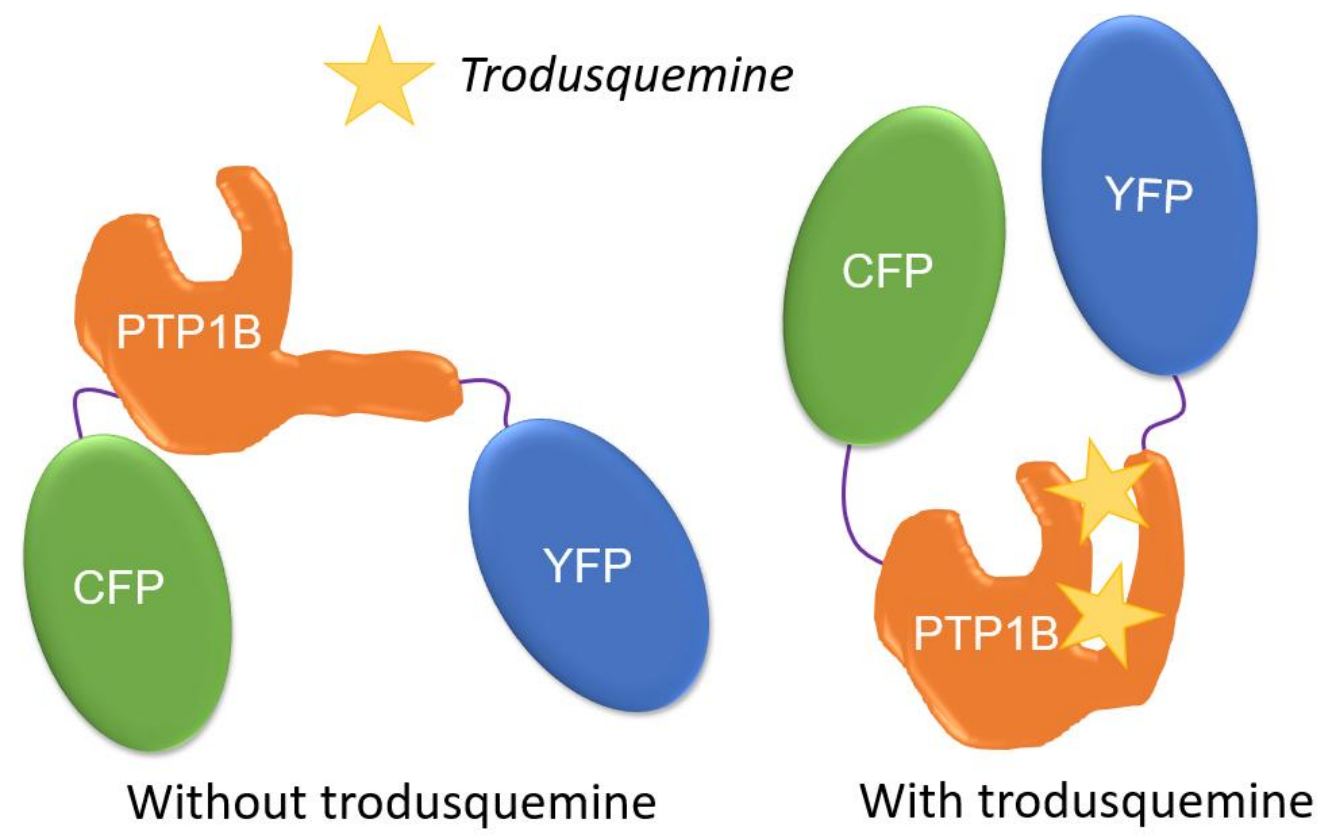

Figure 22. PTP1B fusion protein tagged with $\mathrm{CFP}$ and $\mathrm{YFP}$ on the $\mathrm{N}$ - and $\mathrm{C}$ - terminus respectively with and without action of trodusquemine.

It has been demonstrated that the administration of trodusquemine to the hypothalamus, restored central insulin signaling and improved the response of peripheral tissues to insulin on mice. [161] Furthermore, the inhibition of PTP1B by 69 prevents and reverses atherosclerotic plaque formation on mice and allows to demonstrate that PTP1B plays a central role in the regulation of endoplasmic reticulum stress in the endothelium. [162, 163]

\section{IV-1-2-2 Trodusquemine activity against non-alcoholic fatty disease}

On account of global obesity epidemic, non-alcoholic fatty disease (NASH) became the first cause of chronic disease of the liver, characterized by an excessive accumulation of fat in the liver. [164] In this context, trodusquemine possesses an activity against NASH which is associated with insulin resistance and diabetes by decreasing hepatic lipid synthesis, stimulating lipolysis and demonstrating its role as an insulin sensitizer (Figure 23). [165] 


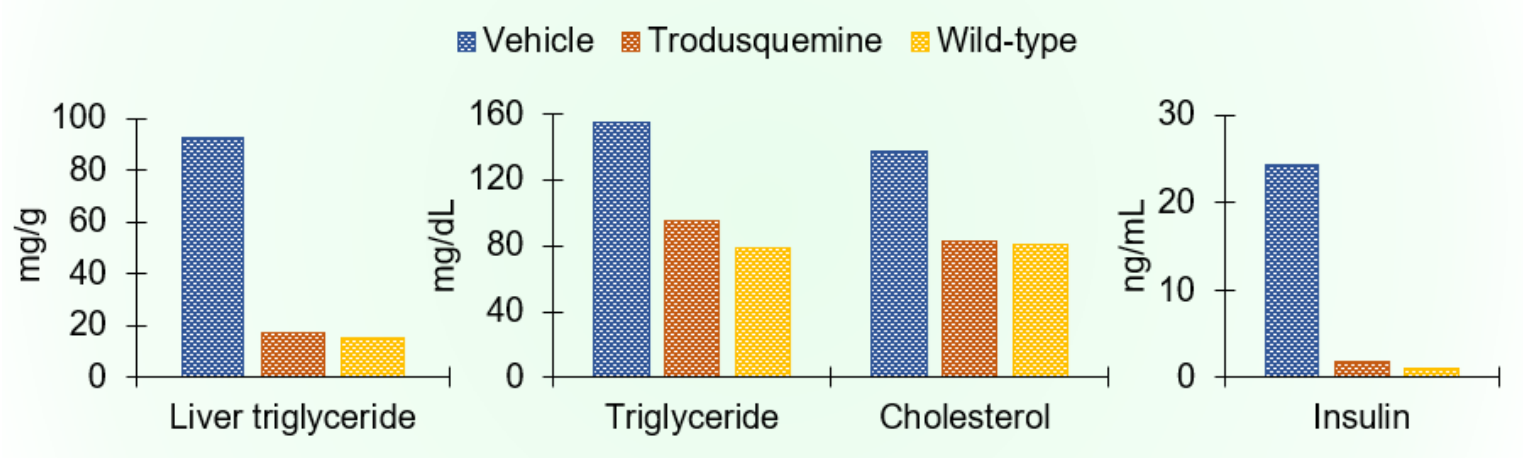

Figure 23. Comparison of the biochemical parameters in wild-type and Lep ${ }^{\mathrm{ob} / \mathrm{ob}}$ mice with or without administration of trodusquemine.

\section{IV-1-2-3 Trodusquemine activity in regenerative medicine}

Regenerative medicine, the most recent and emerging branch of medical science, deals with functional restoration of tissues or organs for the patients suffering from severe injuries or chronic disease. [166] In this context, it was demonstrated that the treatment of adult zebrafish with trodusquemine increased the rate of regeneration of the amputated caudal fin. [167] Furthermore, the administration of trodusquemine to adult mice after induction of myocardial infraction, increased survival and cardiomyocyte proliferation, improved heart function, reduced infarct size and ventricular wall thinning. [167] Studies are now under current investigation for a therapeutic human use.

\section{IV-1-2-3 Trodusquemine activity against neurodegenerative diseases}

As its closely related compound squalamine, trodusquemine possesses an activity against aggregation of the $\alpha$-synuclein and inhibits also a secondary nucleation pathway of $\alpha$ synuclein

(fibril-dependent)

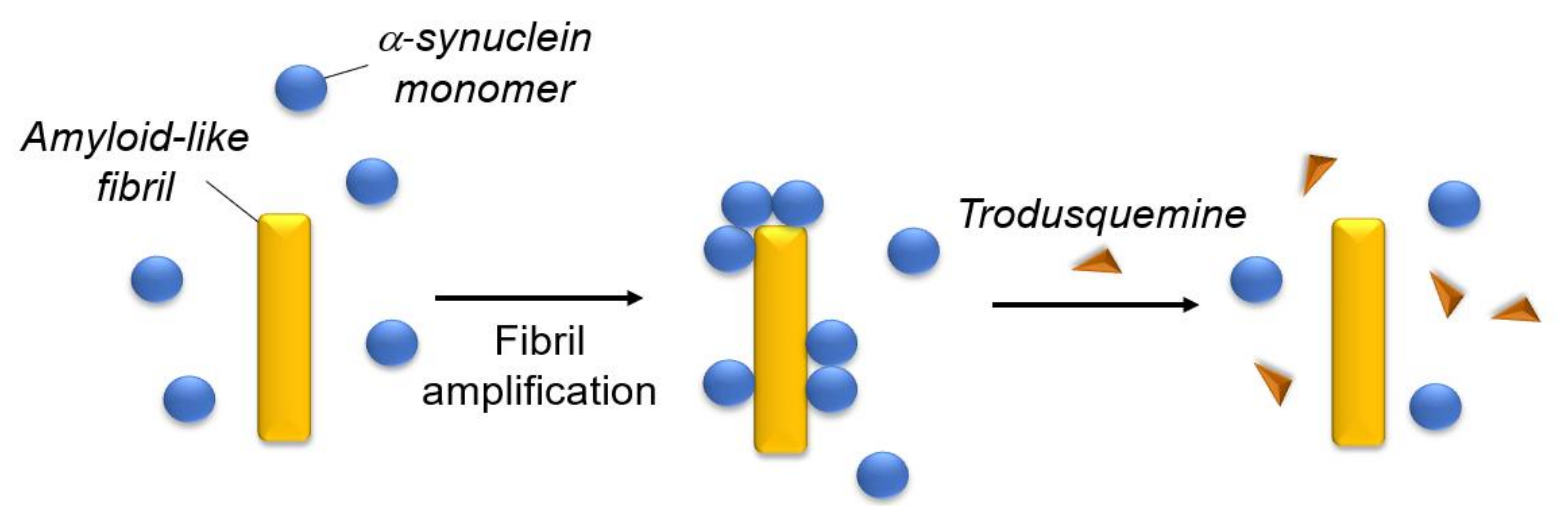


Figure 24), leading to a decrease of the toxicity of $\alpha$-synuclein oligomers in neuronal cells. [168] Moreover, its administration after the initial growth phase, lead to a dramatical reduction in the number of $\alpha$-synuclein inclusions, therefore in Parkinson disease it eliminated the related muscle paralysis and increased lifespan. [168] Thus, it was demonstrated that trodusquemine enhances the rate of aggregation of residue 42 from the amyloid- $\beta$-peptide, a key pathogenic agent in Alzheimer disease, but significantly reduces the toxicity of the resulting oligomers. [169]

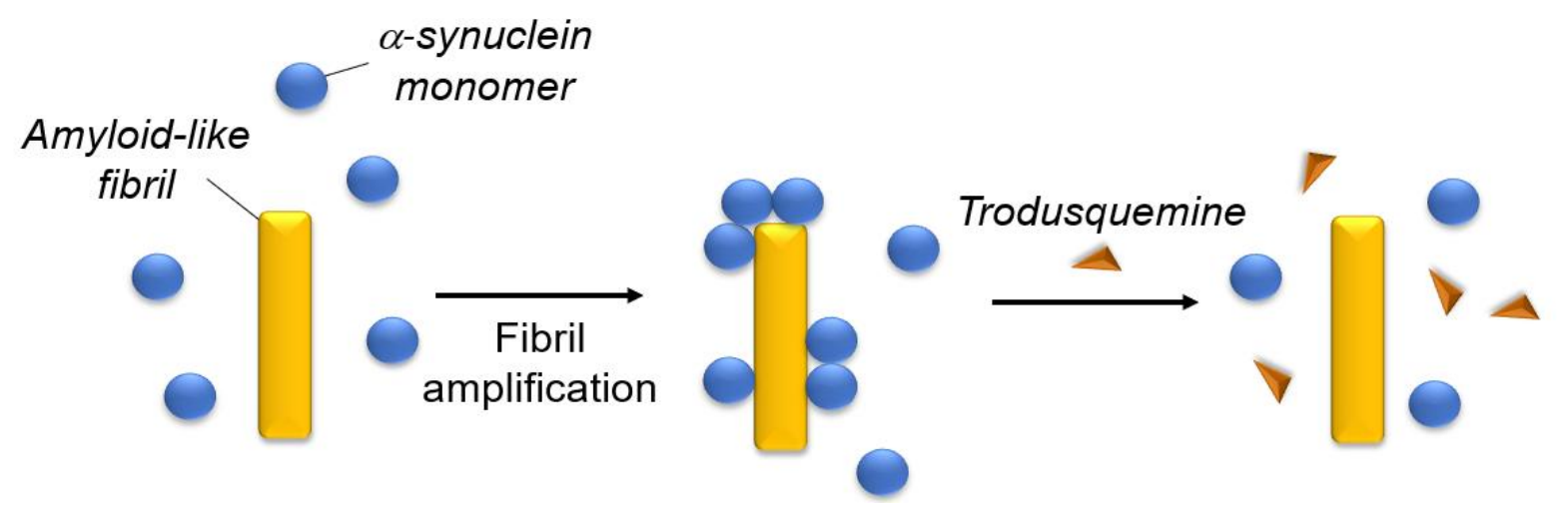

Figure 24. Effect of trodusquemine on fibril amplification.

\section{IV-2 Polyamines from sponges}

Marine environment constitutes an amazing store house of novel bioactive natural compounds, with structural and chemical features generally not encountered in terrestrial natural ones. [170] Thus, recent investigations devoted to the search of polyamine derivatives in marine sponges were successful as illustrated above.

\section{IV-2-1 Ianthelliformisamines}

The study of marine sponges Suberea ianthelliformis and Pseudoceratina purpurea allowed to isolate bromotyrosine-derived chemicals namely ianthelliformisamine A, B and C and tokaradine $C$, respectively $\mathbf{8 4 , ~ 8 5 , ~} 86$ and 87 (Figure 25). [171, 172] These compounds are all characterized by a 3,5-dibromo-4-methylanisole group linked to a spermine for ianthelliformisamine A 84, a spermidine for ianthelliformisamine B 85 and tokaradine C 87 whereas a spermidine coupled with two 3,5-dibromo-4-methylanisole group for ianthelliformisamine C 86. [171] 
<smiles>[R]NC(C)NC(C)NC(=O)/C=C/c1cc(Br)c(OC)c(Br)c1</smiles>

lanthelliformisamine A 84

lanthelliformisamine B 85

lanthelliformisamine C 86

Tokaradine C 87 $\mathrm{n}=3 \quad \mathrm{~m}=4 \quad \mathrm{R}=\widetilde{\mathrm{NH}_{2}}$

$n=3 \quad m=4 \quad R=H$

$\mathrm{n}=3 \mathrm{~m}=4 \mathrm{R}=\mathrm{H}_{\mathrm{Br}}^{\mathrm{B}}$

$n=4 \quad m=3 \quad R=H$<smiles>COc1c(Br)cccc1Br</smiles>

Figure 25. Chemical structures for ianthelliformisamines A-C 84-86 and tokaradine C 87.

In 2014, two different synthetic pathways were described to achieve ianthelliformisamines A-C and tokaradine C synthesis. [173, 174] The one described here used the same intermediate 90 obtained from 3,5-dibromo-4-hydroxybenzaldehyde $\mathbf{8 8}$ through methylation of the hydroxyl group then followed by a Wittig reaction with the phosphonium 89. [173] 90 was then coupled with spermine 4 to afford ianthelliformisamine A and $\mathrm{C}$ with overall yields of $25 \%$ and $58 \%$, respectively. [173] On the other hand, the intermediate 90 was coupled with either spermine intermediates bis protected 91 or 92 to afford ianthelliformisamine B and tokaradine $\mathrm{C}$ in 67 and $76 \%$ of yield, respectively (Figure 26). [173]<smiles>O=Cc1cc(Br)c(O)c(Br)c1</smiles>

88<smiles>CCOC(=O)C=Pc1ccccc1</smiles>

89<smiles>COc1c(Br)cc(/C=C/C(=O)O)cc1Br</smiles>

90

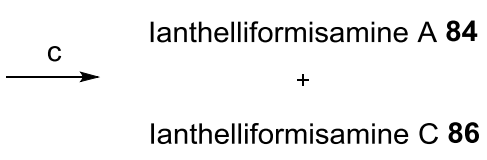

lanthelliformisamine C 86

lanthelliformisamine B 85<smiles>COc1c(Br)cc(/C=C/C(=O)O)cc1Br</smiles><smiles>CCCCCCCN(CCCCN)C(=O)OCCCC</smiles>

or

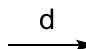<smiles>CCCCOC(=O)NCCCN(CCCCN)C(=O)CCCC</smiles>

Tokaradine C 87

Figure 26. Synthetic pathway for the preparation of ianthelliformisamines A-C and tokaradine C. Reagents and conditions: (a) MeI (1.2 equiv), $\mathrm{K}_{2} \mathrm{CO}_{3}, \mathrm{DMF}, 96 \%$; (b) 1) 88 , toluene, 2) $\mathrm{LiOH}, \mathrm{THF} / \mathrm{H}_{2} \mathrm{O}, 87 \%$; (c) Spermine 4, $\mathrm{HOBt} / \mathrm{DCC}$ (1.1 equiv), $\mathrm{CH}_{2} \mathrm{Cl}_{2}$, yields: $30 \%$ 84, 70\% 86; (d) 1) $\mathrm{HOBt} / \mathrm{DCC}$ (1.1 equiv), $\mathrm{CH}_{2} \mathrm{Cl}_{2}, 2$ ) $\mathrm{HCl}, 1 \mathrm{M}$ in $\mathrm{Et}_{2} \mathrm{O}$, yields: $80 \% \mathbf{8 5}$, $91 \% 87$.

On a biological point of view, ianthelliformisamines 84 and 86 were reported to possess antibacterial activities against $P$. aeruginosa and $S$. aureus with MIC values of 35 $\mu \mathrm{M}$, and $17.5 \mu \mathrm{M}$, respectively. [171, 173, 174] Furthermore, 84 and $\mathbf{8 5}$ possess an activity 
against E. coli with MICs of $11.04 \mu \mathrm{M}$ and $14.5 \mu \mathrm{M}$, respectively. [174] It is noteworthy that Khan et al. demonstrated no activity of $\mathbf{8 6}$ against $S$. aureus ATCC 25923, whereas Pieri et al. reported a MIC of $12.5 \mu \mathrm{M}$ against $S$. aureus DSM 799. [173, 174] On the other hand, 86 possesses an antibacterial activity against Gram-negative bacteria $P$. aeruginosa and $K$. pneumoniae with MICs of $25 \mu \mathrm{M}$ and $12.5 \mu \mathrm{M}$, respectively. [173]

Afterwards, ianthelliformisamines and tokaradine $\mathrm{C}$ tested in combination with classic antibiotics, were studied for their ability to bypass the different mechanisms of resistance of Gram-negative bacteria and thus improve the activity of inactive antibiotics. [173] Thus, compounds 85-87 used at a 3.12-12.5 $\mu \mathrm{M}$ concentration can restore the activity of doxycycline used at $2 \mu \mathrm{g} / \mathrm{mL}$ against $E$. aerogenes, $P$. aeruginosa and $K$. pneumoniae. [173] In the same way, compounds $\mathbf{8 6}$ and 87 at 1.6 and $3.12 \mu \mathrm{M}$ concentration, respectively, can restore the activity of cefepime used at a $2 \mu \mathrm{g} / \mathrm{mL}$ concentration against $P$. aeruginosa. [173]

Additionally, the parasitic-specific activity of ianthelliformisamines against Plasmodium falciparum (3D7) was investigated demonstrating that ianthelliformisamines C 86 is the most active with an $\mathrm{IC}_{50}$ of $4.4 \mu \mathrm{M}$, while ianthelliformisamines $\mathrm{A}$ and $\mathrm{B}$ are less active with $\mathrm{IC}_{50}$ ranging from 14.5 to $12.1 \mu \mathrm{M}$, respectively. [175]

\section{IV-2-2 Protoaculeines}

The study of another marine sponge Axinyssa aculeata allowed to discover protoaculeine B 93 and a long-chain polyamine LCPA-Aa 94 (Figure 27). [176, 177] Protoaculeine B 93 is structurally composed of a tryptophan-derived hetero tricycle and a long-chain polyamine that is a linearly extended 14 monomers of 1,3-propanediamine and belongs to the toxin peptide aculeines family whereas LCPA-Aa 94 is a linear compound consisting of 5 to 15 monomers of 1,3-propanediamine. [176-178]

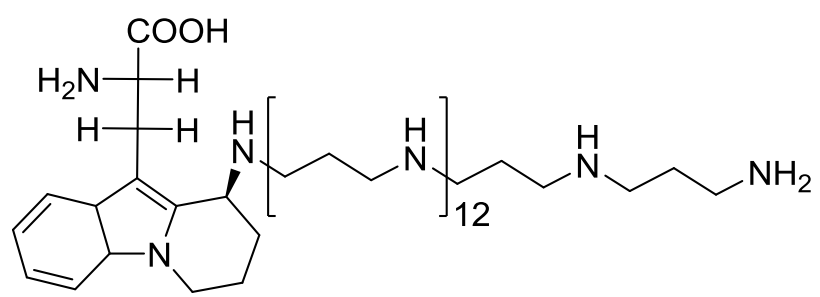

Protoaculeine B 93

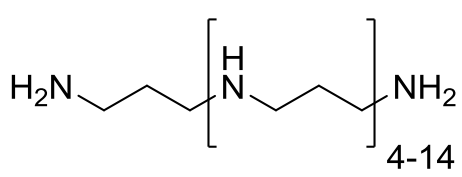

LCPA-Aa 94

Figure 27. Chemical structures of protoaculeine B 93 and LCPA-Aa 94.

To achieve the chemical synthesis of protoaculeine B 93, a synthetic strategy was developed involving the preparation of the fully protected product 102, in 21 steps with an overall yield of $0.70 \%$ (Figure 28). [178] Protoaculeine B 93 was thus prepared from two key 
fragments: heterotricyclic N-Ns amine and hydroxylated LCPAs, which were assembled through a Mitsunobu reaction. [178] The heterotricyclic N-Ns amine fragment 98 was achieved in 14 steps, starting from DL-tryptophan 95, while the hydroxylated LCPAs was afforded in 7 steps from $N$-NPEC-N-Ns amine 99 by an iterative sequence including a split, a NPEC photodegradation, a Tr deprotection and finally a Mitsunobu coupling. [178]

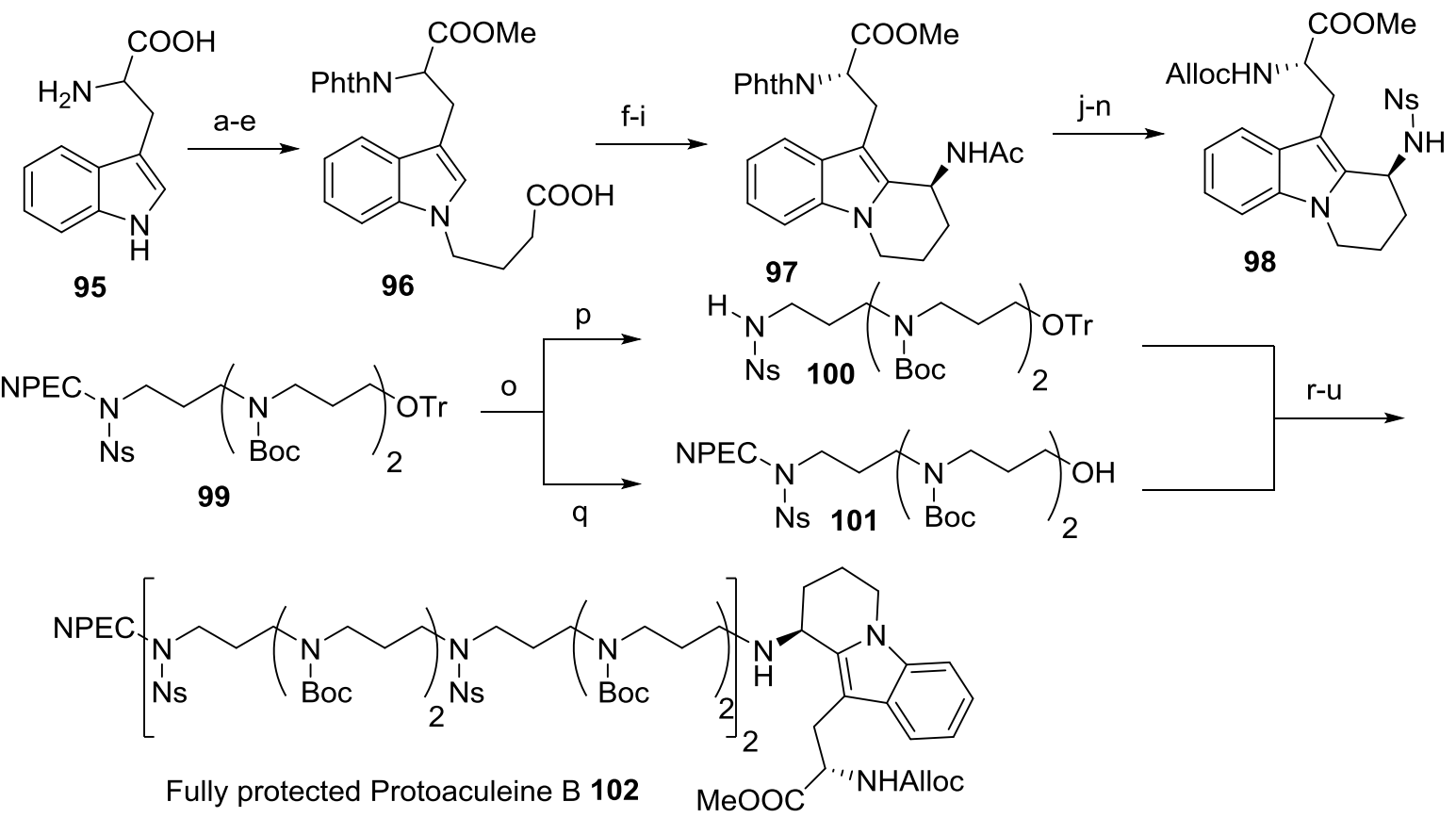

Figure 28. Synthetic pathway to afford the fully protected protoaculeine B 102. Reagents and conditions: (a) 1) phthalic anhydride pyridine, reflux, 2) AcCl, $\mathrm{MeOH}, 91 \%$; (b) allyl bromide $\mathrm{Cs}_{2} \mathrm{CO}_{3}$, DMF, 93\%; (c) tert-butyl acrylate Zhan catalyst-1B, benzene, 65\%; (d) $\mathrm{H}_{2}, 5 \% \mathrm{Pd} / \mathrm{C}$, EtOAc, 93\%; (e) TFA, $\mathrm{CH}_{2} \mathrm{Cl}_{2}, 100 \%$; (f) $\mathrm{P}_{2} \mathrm{O}_{5}, p$-xylene, reflux, $72 \%$; (g) $\mathrm{NH}_{2} \mathrm{OH} \cdot \mathrm{HCl}$, pyridine, reflux, 95\%; (h) $\mathrm{Fe}(\mathrm{OAc})_{2}, \mathrm{Ac}_{2} \mathrm{O}, \mathrm{AcOH}, \mathrm{THF}, 65 \%$; (i) $\mathrm{H}_{2}, 5 \% \mathrm{Pd} / \mathrm{C}, \mathrm{EtOH}$ (0.03M), 89\%; (j) $\mathrm{Boc}_{2} \mathrm{O}$, DMAP, THF, reflux, 79\%; (k) $\mathrm{H}_{2} \mathrm{NNH}_{2} \cdot \mathrm{H}_{2} \mathrm{O}$, THF, reflux, 85\%; (l) AllocCl, Et 3 N, $\mathrm{CH}_{2} \mathrm{Cl}_{2}, 87 \%$; (m) 1) TBSOTf, 2,6-lutidine, $\mathrm{CH}_{2} \mathrm{Cl}_{2}$, 2) $\mathrm{Bu}_{4} \mathrm{NF}$, THF, $100 \%$; (n) $\mathrm{NsCl}, \mathrm{Et}_{3} \mathrm{~N}, \mathrm{CH}_{2} \mathrm{Cl}_{2}, 99 \%$, (o) 1) split; (p) 2) hn (high-pressure $\mathrm{Hg}$ lamp, $435 \mathrm{~W}$ ), $\mathrm{MeOH}$ $(0.0023 \mathrm{M}), 0^{\circ} \mathrm{C}, 94 \%$ : NPEC photodegradation; (q) 2') TFE, reflux, 88\%: Tr deprotection; (r) 3) $\mathrm{DEAD}, \mathrm{PPh}_{3}, \mathrm{PhH}, 82 \%$ : Mitsunobu coupling; (s) iterative sequence: 1) split, 2) NPEC photodegradation, 81\%, 2') Tr deprotection, 55\% (87\% brsm), 3) Mitsunobu coupling, 78\%; (t) Tr deprotection: TFE, $40 \%$ (90\% brsm); (u) heterotricycle fragment 98, DEAD, $\mathrm{PPh}_{3}$, $\mathrm{PhH}, 63 \%$

It was demonstrated that LCPA-Aa 94 is a chemical factor involved in silica depositions in sponges. [177] LCPA was also reported to interact with bilayers to form three-dimensional 
stacks on the surface of artificial lipid membranes, but the stack formation is highly dependent on the number of polyamine units present in the LCPA. [178, 179]

\section{IV-2-3 Motuporamines}

Marine sponges are a rich source of structurally novel metabolites of interest as potential lead compounds for the development of new drugs. [180] In this context, extracts of the tropical sponge Xestospongia exigua (Kirkpatrick) lead to the isolation of macrocyclic polyamines, namely motuporamines A to I 103-111 (Figure 29). [180, 181]

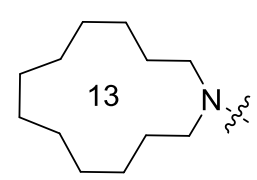

Motuporamine A 103

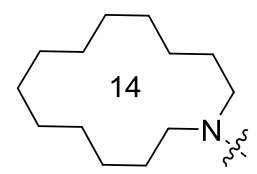

Motuporamine B 104

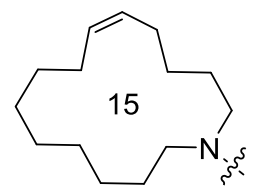

Motuporamine C 105

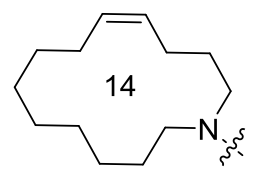

Motuporamine D 106

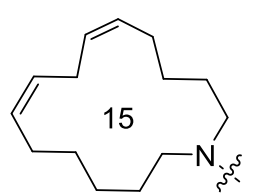

Motuporamine E 107 Motuporamine G,H,I 109-111

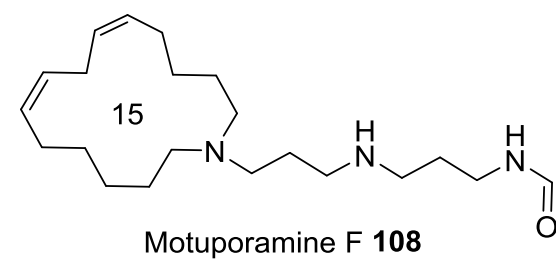<smiles>CC(C)(C)CCNCCCN</smiles>

Figure 29. Chemical structures of motuporamines A to I 103-111.

Since their isolations, different synthetic pathways were described to achieve motuporamines A 103, B 104, C 105 and G 109 preparation (Figure 30). Thus, the synthesis of motuporamines A 103 and B 104 were performed from either 2-azacyclotridecanone 112 or a mixture of 2-azacyclotetrade-cenones 116 and 117 in 4 steps, with overall yields of $85 \%$ and 75\%, respectively. [182] 2-azacyclotridecanone 112 was also used to afford $\mathbf{1 0 3}$ in 8 steps (25\% overall yield) whereas cyclododecanone 115 was involved to achieve the synthesis of 104 in 11 steps (8\% overall yield), both involving a key step of reductive amination using sodium triacetoxyborohydride. [183] Afterwards, an iterative ring-expansion method was developed to achieve 103 from 1-benzyl-2-vinylpyrrolidine 113 and 104 from 1-benzyl-2vinylpiperidine 114, by a tandem conjugate addition to ( $p$-toluenesulfonyl) ethyne and a formal 3-aza-Cope rearrangement. [184, 185] The motuporamine C $\mathbf{1 0 5}$ was obtained in 6 steps synthesis with $45 \%$ overall yield, starting from N-(dec-9-en-1-yl)hex-5-enamide 118 and involving a ring-closing metathesis reaction, a Michael addition and an amide formation reaction to introduce the spermine-like unit. [182] Thus, the same starting material was used to afford 105 using a Z-selective catalyzed ruthenium macrocyclization. [186] Otherwise, the synthesis of 105 was achieved from 9-undecyn-1-ol 119 in 8 steps with an overall yield of 12\%. [187] In 2012, the synthesis of motuporamine G 109 was achieved through a three steps 
synthesis from 2-(prop-1-en-2-yl)cyclononan-1-one $\mathbf{1 2 0}$ and by using a tandem nucleophilic addition as well as an oxy-2-aza-cope rearrangement. [188]

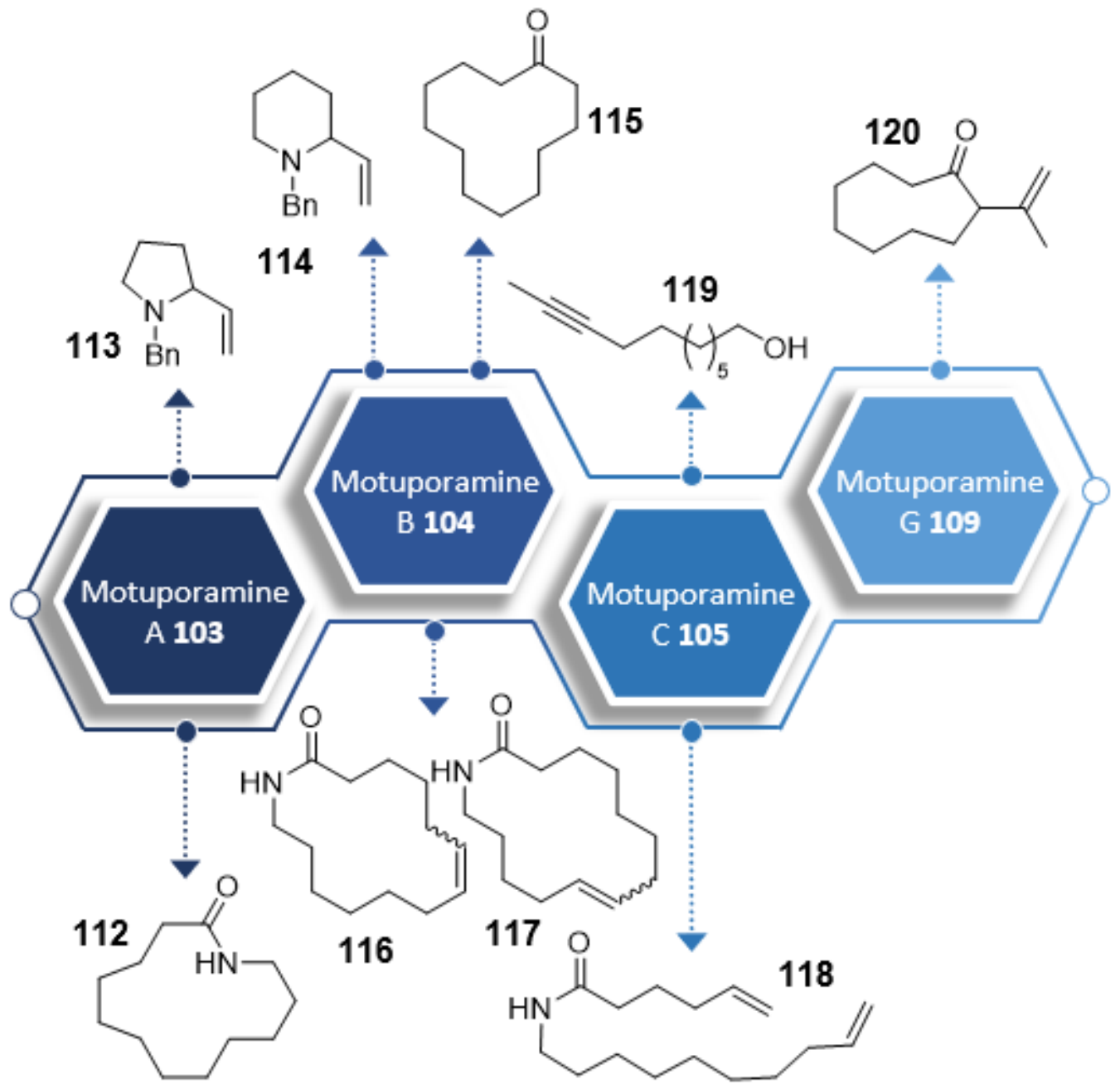

Figure 30. Synthetic pathways involved to prepare motuporamines A 103, B 104, C 105 and G 109.

On a biological point of view, it was demonstrated that motuporamines possess antiinvasive and anti-angiogenic activities against cancer cells with a mean $\mathrm{IC}_{50}$ of $0.6 \mu \mathrm{g} / \mathrm{mL}$ (Figure 31). [180] On the other hand, they were identified as inhibitors of invasion of breast carcinoma cells and the more potent anti-invasive compound is motuporamine $\mathrm{C}$ which interferes with the migration and leading edge ruffling of human breast cancer cells, prostate carcinoma cells and glioma cells. [189] Furthermore, motuporamine C inhibits angiogenesis in both an in vitro sprouting assay and an in vivo chick chorioallantoic membrane assay, with a low cytotoxicity. [189] Afterwards, it was demonstrated that motuporamine C inhibits the motility of MDA-231 human breast cancer cells in vitro and it is believed that this is the basis of its anti-invasive and anti-angiogenic properties. [181] 


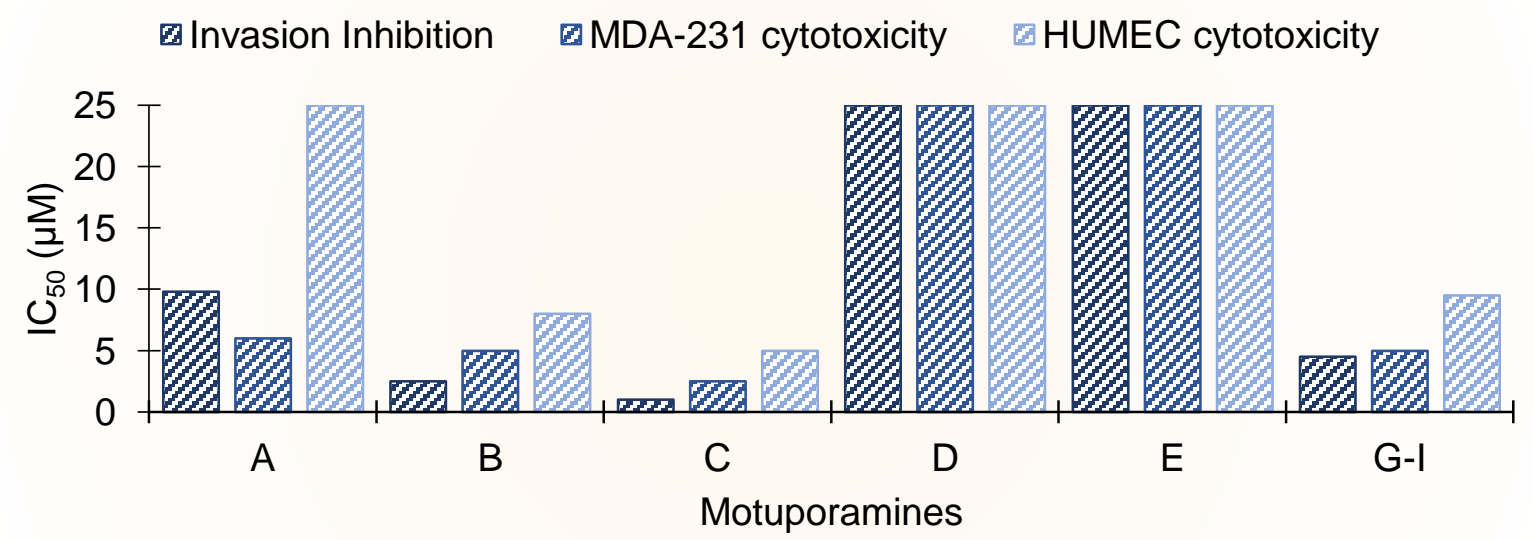

Figure 31. Anti-invasion and cytotoxicity data for motuporamines A-E and G-I.

It is also noteworthy that non-natural motuporamine derivatives were recently prepared and are now widely studied for their interesting anti-angiogenic and antimicrobial activities. [190195]

\section{V-Polyamines from microorganisms}

Microorganisms play an essential role in almost all ecosystem and some of them use polyamines to adapt and survive in all these environments. In this section we will focus our attention on the recent discovery of new polyamine derivatives from bacteria and fungi presenting interesting biological activities.

\section{V-1-Petrobactins}

In 2002, spermidine containing compounds namely petrobactin $\mathbf{1 2 1 - 1 2 3}$ were isolated from an oil-degrading marine bacterium Marinobacter hydrocarbonoclasticus as well as from Marinobacter aquaolei (Figure 32). It is also noteworthy that petrobactin $\mathbf{8 9}$ was found in Bacillus anthracis the causative agent of anthrax and some other bacteria from Bacillus group. [196-201]

The first isolation and characterization of petrobactin supposed a structure possessing 2,3-dihydroxybenzoyl functions. [196] Nevertheless, its synthesis was not conclusive and the preparation of the compound with 3,4-dihydroxybenzoyl groups permitted to confirm the correct structure of naturally isolated petrobactin 121. [202] 


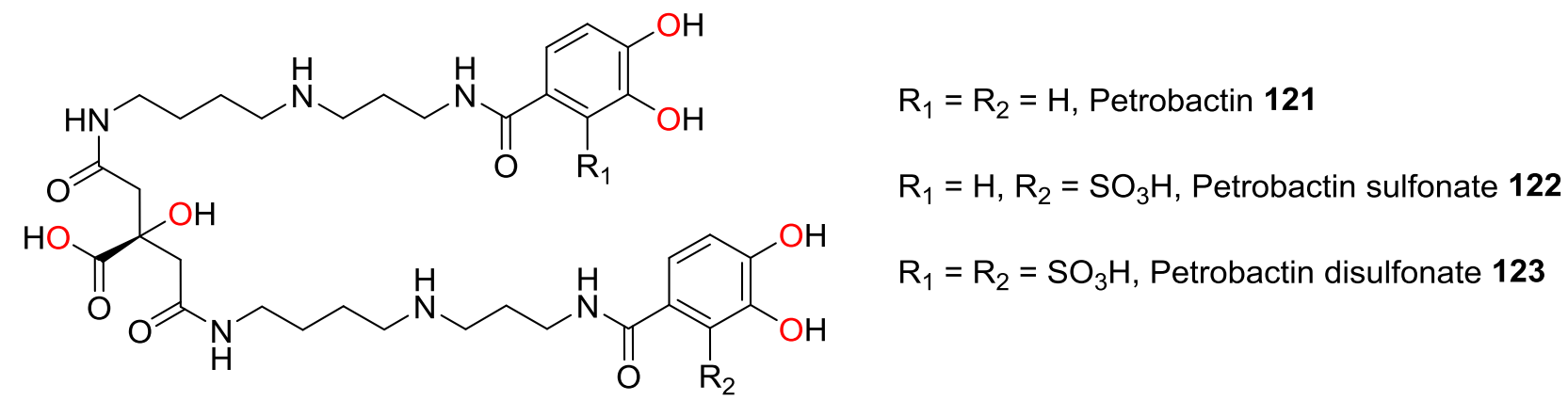

Figure 32. Chemical structures of petrobactin 121, petrobactin sulfonate 122 and petrobactin disulfonate 123. The iron-coordinating atoms are indicated in red.

Petrobactin is a siderophore i.e. a highly specific Fe(III) transport ligand secreted by bacteria under conditions of iron stress to scavenge and transport iron. [196, 203] For a siderophore, possess a 2,3-dihydroxybenzoyl function is classical, whereas the presence of a 3,4-dihydroxybenzoyl group is quite unusual. [202] The siderophore part is composed by a bis-catechol $\alpha$-hydroxy acid which is bound to iron to form the Fe(III)-petrobactin complex 124. [196, 204] On account of the presence of a citryl group, the ferrated form might be photolabile. Thus, when FePB $\mathbf{1 2 4}$ is exposed to the light it readily performed a decarboxylation reaction, followed by the reduction of Fe(III) into Fe(II) (Figure 33). [196, 203] Furthermore, petrobactin has also an unexpected binding affinity for boron through the catechol groups of petrobactin to form a borate-petrobactin complex permitting the development of methods to study petrobactin either in the bacteria or in seawater. [205-210]

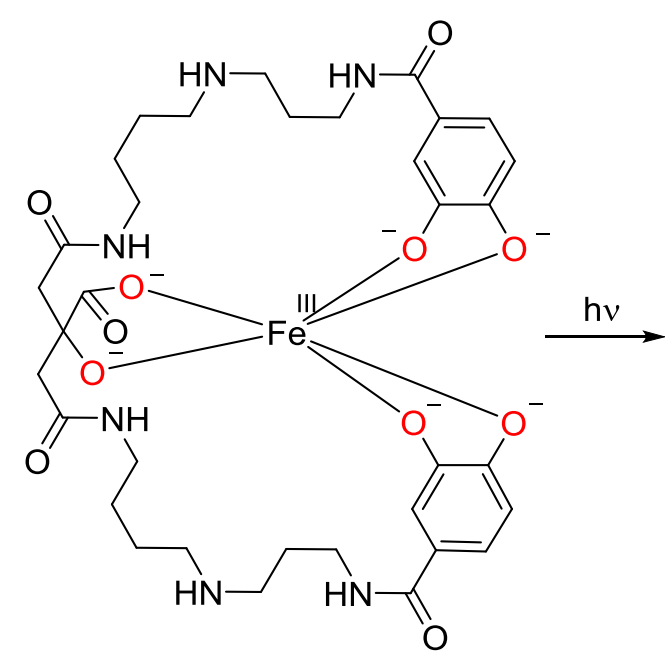

Fe(III)-petrobactin (FePB) 124

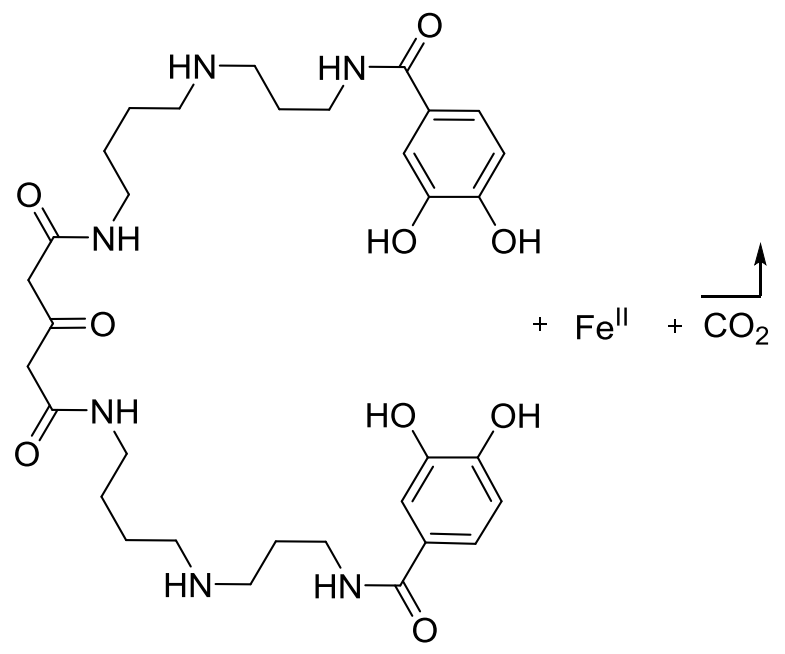

Decarboxylated petrobactin $\left(\mathrm{FePB}^{v}\right) 125$

Figure 33. Photochemical transformation of FePB 124 into $\mathrm{FePB}^{v} 125$. 
Since its discovery, few chemical syntheses of petrobactin were performed. [202, 211, 212] Thus, the synthetic pathway described below was purposed by Bugdanh et al. in 2014 in 9 steps with $19 \%$ overall yield (Figure 34). [207, 213]

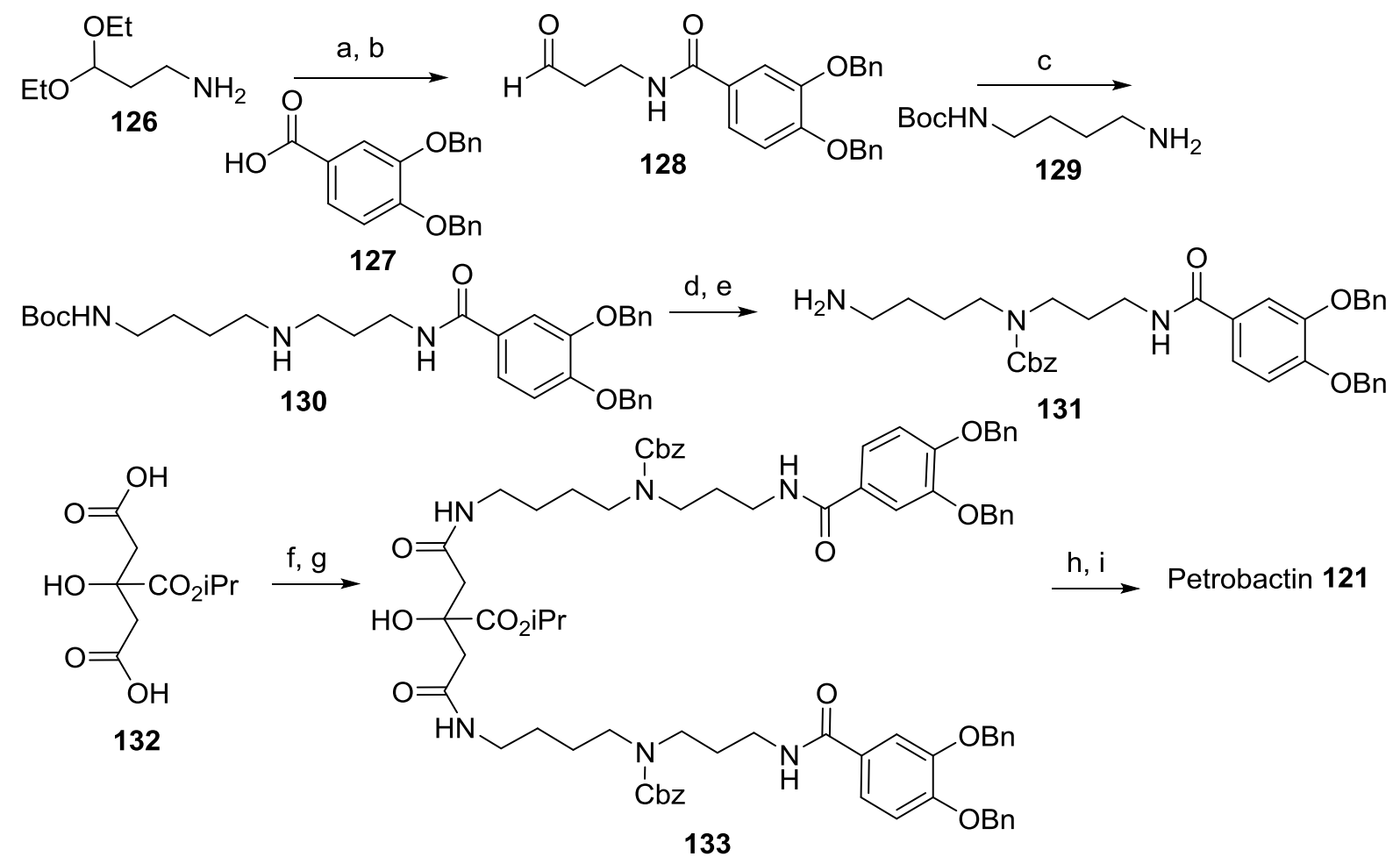

Figure 34. Synthesis pathway for the preparation of petrobactin 121. Reagents and conditions: (a) 127, EDC, HOBt, Et $3 \mathrm{~N}, \mathrm{DMF}, 92 \%$; (b) PPTS, acetone $/ \mathrm{H}_{2} \mathrm{O}, 40^{\circ} \mathrm{C}, 96 \%$; (c) 129, $\mathrm{NaBH}(\mathrm{OAc})_{3}, \mathrm{Et}_{3} \mathrm{~N}, \mathrm{MeOH}, 71 \%$; (d) $\mathrm{CbzCl}, \mathrm{Et}_{3} \mathrm{~N}, \mathrm{MeOH}, 94 \%$; (e) $\mathrm{TFA}, \mathrm{CH}_{2} \mathrm{Cl}_{2}, 0^{\circ} \mathrm{C}$, 95\%; (f) PNP, DCC, 74\%; (g) 131, Et 3 N, 69\%; (h) LiOH, $0^{\circ} \mathrm{C}$; (i) $\mathrm{H}_{2}, \mathrm{Pd} / \mathrm{C}, 62 \%$ (2 steps)

The synthesis of the petrobactin spermidine side chain 131 was realized from commercially available diethyl acetal of 3-aminopropanal 126 and the bis protected 3,4bis(benzyloxy)benzoic acid 127 easily obtained from 3,4-dihydroxybenzoic acid. [207, 211] The isopropyl-protected citric acid building block 132 was activated by treatment with paranitrophenol and DCC for amide coupling reaction with the petrobactin spermidine side chain 131 to provide the fully protected petrobactin 133. The isopropyl ester was then removed by treatment with aqueous lithium hydroxide and followed by the removal of the $\mathrm{Cbz}$ and $\mathrm{Bn}$ groups by a subsequent hydrogenolysis to afford petrobactin 121 (Figure 34). [213]

On a biological point of view, it was demonstrated that $B$. anthracis uses petrobactin to scavenge iron from its environment during the infection and increases its full pathogenicity. $[214,215]$ Thus, petrobactin is produced by pathogenic strains but also innocuous isolates 
alike suggesting that it is not itself indicative of virulence but certainly required for pathogenesis (Figure 35). [216] Furthermore, petrobactin evades innate immune response of mammalian, because neither petrobactin nor FePB are substrates for sequestration by siderocalin, a mammalian protein binding with siderophore to prevent iron acquisition by pathogenic bacteria. [214] Nevertheless, a reshaping of siderocalin was developed to specifically bind to FePB with a high affinity, in the aim to reactivate immune response against the pathogenic bacteria. [217]

- BSL1

BSL2

BSL3

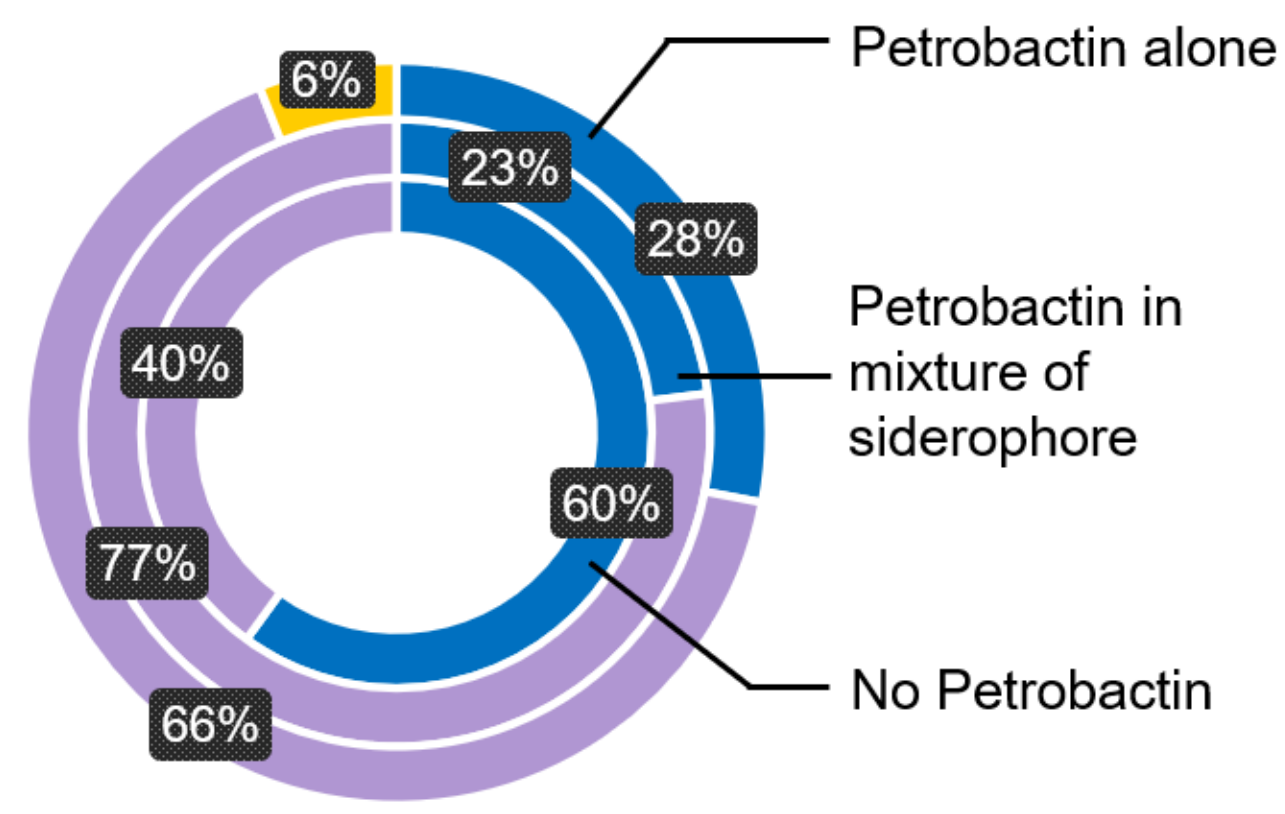

Figure 35. Percentage of strains in each biological safety level (BSL) designation and their siderophore production phenotypes.

The biosynthesis of petrobactin was performed by the asbABCDEF (anthrochelin biosynthesis) gene cluster from $B$. anthracis, starting from 3,4-dihydroxybenzoic acid 134, spermidine 3 and citric acid 135 (Figure 36). [215, 218-226] In addition, it was demonstrated that the whole or a part of the gene cluster that encoded petrobactin was presented in other bacteria. [227, 228] 


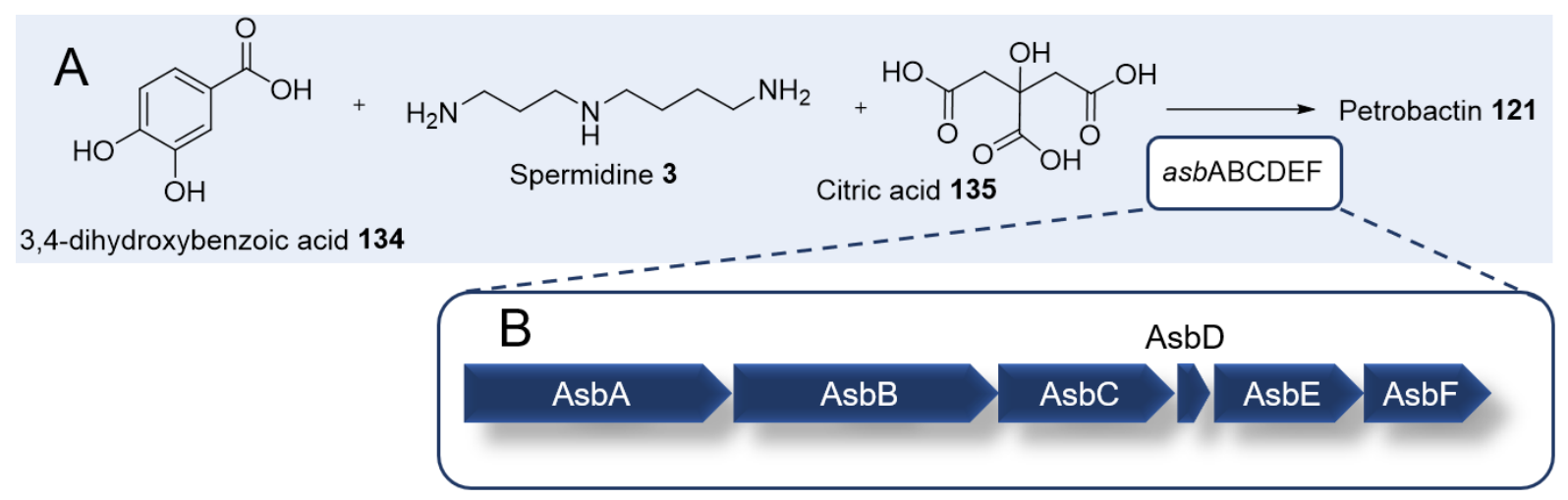

Figure 36. Biosynthesis of petrobactin 121. (A) Different components enter the biosynthesis of petrobactin 121. (B) Enzymes involved in the assembly of petrobactin 121 are encoded by the genes from the asbABCDEF cluster.

The study of the mechanism of transport of petrobactin demonstrated the implication of the $y c l$ NOPQ operon for B. subtilis and the protein FpuA for the import of petrobactin for B. anthracis. [229-231] Indeed, from $\Delta f p u \mathrm{~A}$ bacterial strains, spores were significantly attenuated, and lethal dose was 3,000 times higher than for wild type. [231] It was then demonstrated that for $B$. subtilis the responses of the ferric uptake regulator were performed by FsrA and PerR regulons. [232]

Numerous investigations allow to enlighten a part of the mechanism of transport of petrobactin in B. anthracis (Figure 37). Firstly, petrobactin was exported into peptidoglycan through the apo-petrobactin exporter (ApeX) a member of the resistance-nodulation-cell division family of transporters. [208] In a second step, petrobactin will bind to ferric iron ions to form FePB complex, which is recognized by petrobactin receptor FpuA linked with two permeases and three ATPases to import petrobactin. [233] The last step of the mechanism dealing with the siderophore degradation or the iron release into the bacteria remains still unclear and two hypotheses either metal reduction or siderophore hydrolysis are still under current investigations. [234] 


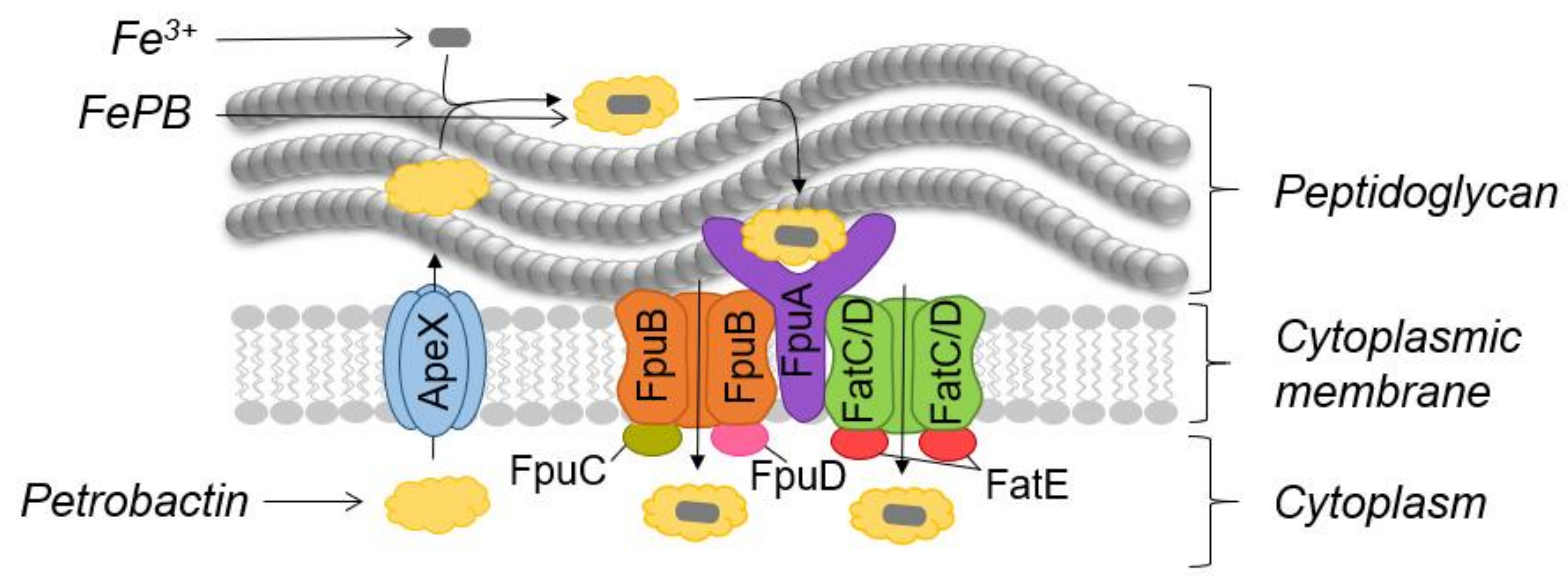

Figure 37. Model for B. anthracis petrobactin export and import.

It was demonstrated that petrobactin is involved in germination of B. anthracis, growth in macrophage, required for sporulation and may be for transmission. [235] Furthermore, petrobactin is accumulated inside the bacteria when medium contains more than $20 \mu \mathrm{M}$ of iron and accumulation is higher in presence of oxygen. [236] Moreover, it was demonstrated that petrobactin is synthesized even in iron-rich conditions and during sporulation, but instead of being exported, petrobactin remains intracellular to protect against oxidative stress and improve sporulation (Figure 38). [235]

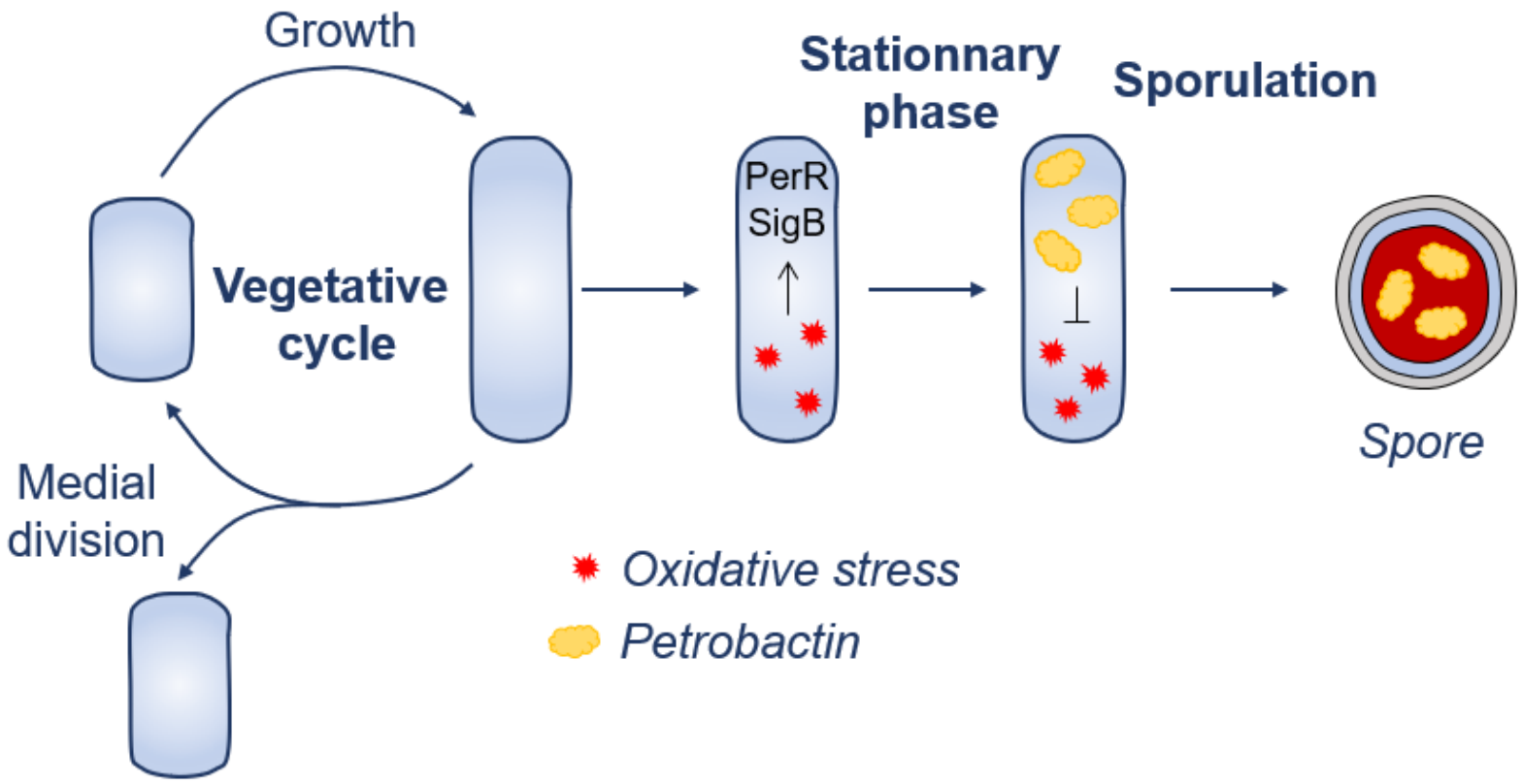

Figure 38. Petrobactin role in B. anthracis during late-stage growth and early sporulation.

\section{V-2-Pistillarins}


Pistillarins constitute another class of polyamine derivatives isolated from fungi and widely studied. Thus, pistillarin 136 presenting two 3,4-dihydroxycatechol groups linked to a spermidine moiety, was encountered in fungi such as Clavariadelphus pistillaris, several Ramaria spp. [237], Penicillium bilaii [238], Rubinoboletus ballouii [239], Gomphus floccosus [240] and Gomphaceae family [241] as well as Clavaria pistillaris and Clavaria fennica (Figure 39). [242]<smiles>CC(C)(C)CCCCNC(=O)c1ccc(O)c(O)c1</smiles>

Figure 39. Chemical structure of pistillarin 136.

The chemical synthesis of pistillarin 136 was achieved in two steps from 3,4dimethoxybenzoic acid 137 and spermidine 3 involving a peptide coupling reaction using CDI, while methylated groups were subsequently deprotected with boron tribromide (Figure 40). [243, 244]<smiles>COc1ccc(C(=O)NCCCCNCCCNC(=O)c2ccc(OC)c(OC)c2)cc1OC</smiles>

Figure 40. Chemical synthesis of pistillarin 102. Conditions and methods: (a) $\mathrm{CDI}, \mathrm{CH}_{2} \mathrm{Cl}_{2}$, overnight, room temperature; (b) $\mathrm{BBr}_{3} / \mathrm{CH}_{2} \mathrm{Cl}_{2}, 97 \%$

It is noteworthy that pistillarin contains the same unusual 3,4-dihydroxycatechol moieties than petrobactin and was demonstrated to act acts as a siderophore for the Gramnegative bacteria Yersinia enterocolitica. [244, 245] Thus, the formation of the complex occurs rapidly in acidic media with an affinity constant for Fe(III) of 29, indicating that pistillarin is a very good ligand for iron(III). [246] Otherwise, pistillarin was demonstrated exhibit significant anti-inflammatory effects on phytohemagglutinin-stimulated human peripheral blood mononuclear cells, by inhibiting $\left[\right.$ methyl- $\left.{ }^{3} \mathrm{H}\right]$-thymidine uptake and inflammatory cytokines productions such as tumor necrosis factor (TNF)- $\alpha$, interleukin (IL)10, interferon (IFN)- $\gamma$ and IL-1 $\beta$ (Figure 41). [239] 


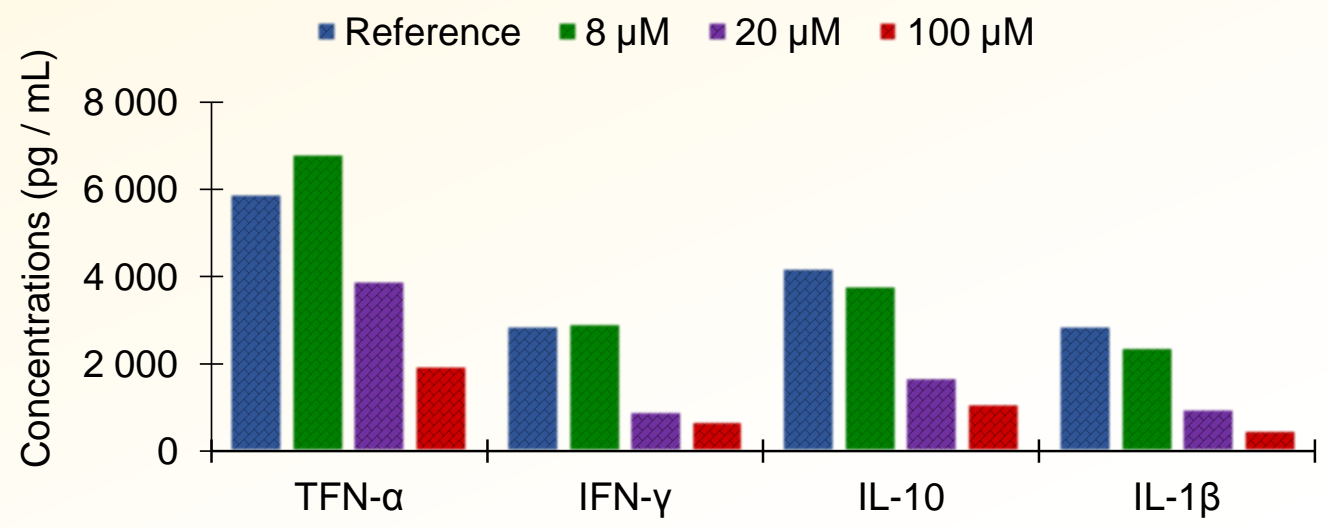

Figure 41. Immunomodulating effect of pistillarin 136 on (TNF)- $\alpha$, (IL)-10(IFN)- $\gamma$ and IL$1 \beta$.

On another biological point of view, pistillarin was then tested against a panel of Grampositive and Gram-negative bacteria as well as fungi and no antimicrobial activity was detected even at high concentrations (MICs > $100 \mu \mathrm{M}$ ). [247] Additionally, pistillarin does not present any cytotoxic effect against the mammalian cell HEK293 and HepG2, with $\mathrm{CC}_{50}$ $>50 \mu \mathrm{M}$. [247] Nevertheless, pistillarin 136 possesses an antimalarial activity in vitro and in vivo against Plasmodium falciparum (3D7) with an $\mathrm{IC}_{50}$ of $1.9 \mu \mathrm{M}$. [175] Since it is wellknown that iron is essential for parasitic growth and multiplication, hence chelation within infected erythrocytes could constitute the mechanism of action of pistillarin to control $P$. falciparum infection. [175] Finally, pistillarin exhibits also significant protective effects against DNA damage, by iron chelation towards hydroxyl radicals generated by the Fenton reaction involving iron and hydrogen peroxide. [240]

\section{VI-Polyamines from plants}

Secondary metabolites of plant origin have long been of interest to man, one of the major reasons in recent years being their use, either directly as precursors or as lead compounds in the pharmaceutical industry. [248]

\section{VI-1-Kukoamine A}

Lycii Cortex, the root bark of Lycium chinens is a famous traditional Chinese herb and a functional food widely consumed in health-preserving cuisines. [249] Thus, from this Chinese medicinal plant was isolated the active compound, a bis(dihydrocaffeoyl) spermine derivative namely kukoamine A 139 and later it was also encountered from the potato Solanum tuberosum (Figure 42). [248, 250] 
<smiles>O=C(CCc1ccc(O)c(O)c1)NCCCNCCCCNCCCNC(=O)CCc1ccc(O)c(O)c1</smiles>

Kukoamine A 139

Figure 42. Chemical structure of kukoamine A 139.

Few synthetic pathways were reported in literature to achieve the synthesis of kukoamine A 139, using either a selective alkylation of spermine or a solid-phase chemistry. [251, 252] Then, Garnelis et al. described a synthesis in 5 steps starting from the 3,4dihydroxybenzaldehyde $\mathbf{1 4 0}$ and involving a Wittig reaction followed by a saponification step and affording the expected intermediate 141. The corresponding crystalline active esters 142 was prepared through a reaction with $N$-hydroxysuccinamide in the presence of $N, N^{\prime}$ dicyclohexylcarbodiimide and the bishydroxycuccimidate salt was easily obtained by reacting with spermine (Figure 43). [253]

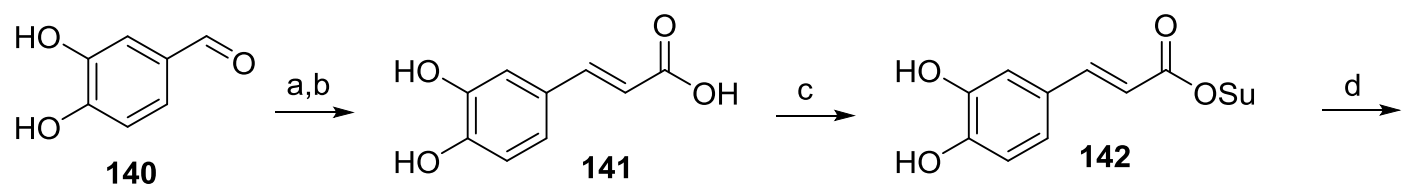<smiles>CCCCNCCCNCCCNC(=O)/C=C/c1ccc(O)c(O)c1</smiles>

Figure 43. Synthesis of kukoamine A 139. Reagents and conditions: (a) $\mathrm{Ph}_{3}=\mathrm{CHCO}_{2}, \mathrm{MeCN}$, reflux, 10 h; (b) 4N NaOH, DMSO / MeOH (2:1), (c) HOSu / DCC, THF / FMD (3:1), $0^{\circ} \mathrm{C}$, (d) Spermine $/ i \mathrm{Pr}_{2} \mathrm{Net}$, (e) $\mathrm{H}_{2}$ (1atm) / 20\% Pd-C, $\mathrm{MeOH} / \mathrm{AcOH} / \mathrm{H}_{2} \mathrm{O}$ (4:1:0.1).

An extractive method of Kukoamine A from the potato peels was also reported permitting to obtain the product with a purity of $90 \%$. [254]

Kukoamine A possesses a widely range of different biological activity such as antihypertensive activity [250], inhibitor of Crithidia fasciculata trypanothione reductase [255], anti-oxidative stress and protection against Fenton-induced damage (Figure 44A). [256-258] Kukoamine A was demonstrated to inhibit human glioblastoma cell growth and migration in vitro and in vivo through apoptosis induction and epithelial-mesenchymal transition attenuation (Figure 44B). [259] Thanks to these both activities, 139 was studied to prevent the detrimental effect of ionizing radiation used during radiotherapy on hippocampal neurons and demonstrated to be neuroprotective compound against radiation-induced brain 
injury though inhibiting neuronal oxidative stress and apoptosis (Figure 44C). [260, 261] Furthermore, it was enlightened that the protection of the brain by kukoamine A occurs through mitochondria apoptosis signaling pathway. [262] Moreover, 139 was used with success as neuroprotective against Parkinson and Alzheimer disease [263, 264] as well as against NASH by attenuating insulin resistance and fatty liver (Figure 44D). [265]
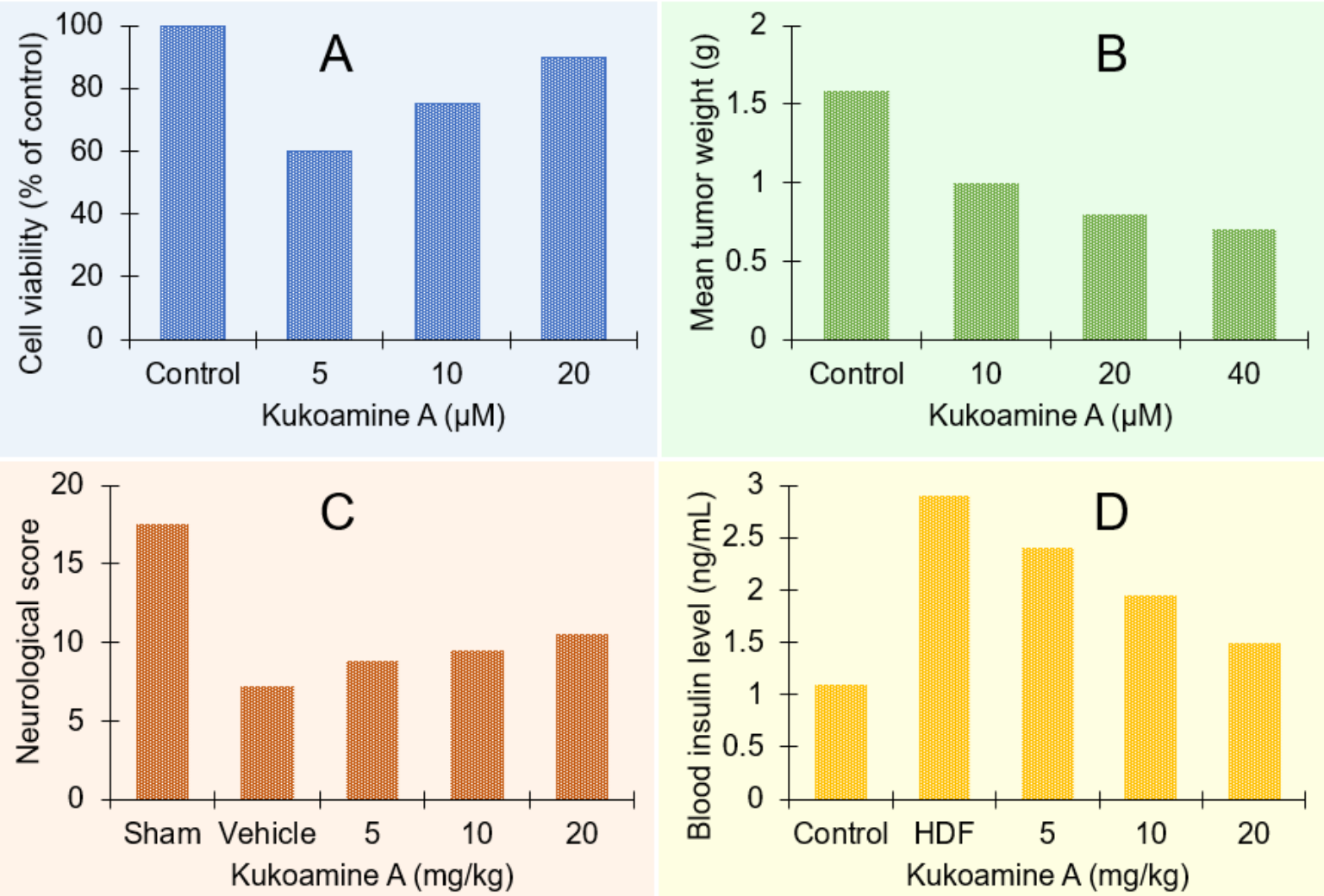

Figure 44. (A) Neuroprotection of kukoamine A in SH-SY5Y cells, dose dependent protective effect of pretreatment with 139 against $\mathrm{H}_{2} \mathrm{O}_{2}(600 \mu \mathrm{M})$ induced cytotoxicity. (B) Inhibition of human glioblastoma growth by Kukoamine A. (C) Dose response study of the neuroprotection afforded by 139, column chart showed corresponding the neurological scores of rats developed by Garcia et al. (D) Effect of $\mathbf{1 3 9}$ on insulin resistance in HFD-fed mice.

\section{VI-2-Putrescine derivatives}

From the corn bran were isolated three compounds $N, N^{\prime}$-Diferuloylputrescine 144, $N, p$ Coumaroyl- $N$ '-feruloylputrescine 145 and $N, N^{\prime}$-Dicoumaroylputrescine 146, all possessing a putrescine core (Figure 45). [266, 267] 


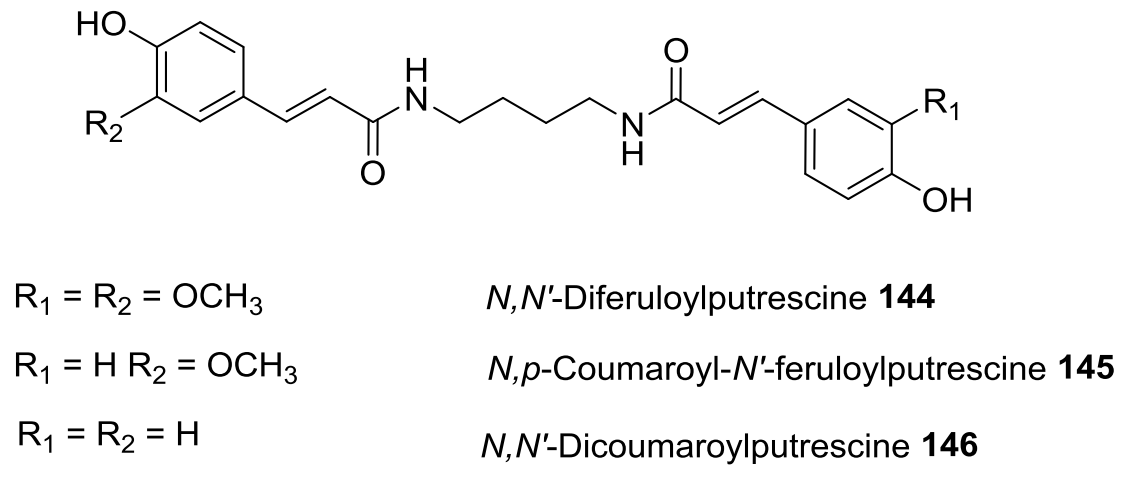

Figure 45. Chemical structure of polyamines 144-146 found in corn bran.

It was demonstrated that these compounds possess antioxidant activity against 1,1diphenyl-2-picrylhydrazyl (DPPH) radical as well as superoxide and hydroxyl radicals generated by enzymatic and nonenzymatic reactions. [267] Thus, 144 showed potent DPPH $\left(\mathrm{IC}_{50}=38.46 \mu \mathrm{M}\right)$ and superoxide $\left(\mathrm{IC}_{50}=291.62 \mu \mathrm{M}\right)$ radical scavenging activities, while 146 exhibited the strongest hydroxyl radical scavenging activity $\left(\mathrm{IC}_{50}=120.55 \mu \mathrm{M}\right)$. [267]

\section{Conclusion}

Natural polyamines appear as essential for life and are widely involved for growth cells, cellular reparation, gene transcription, proteins, and nucleic acids synthesis. On the other hand, due to their structure and physical properties, polyamine derivatives open the way to the development of new class of anticancer, antifungal, or antimicrobial agents against MDR pathogens and could become a last-line therapeutic drug in the coming fifty years. Indeed, development in these fields could lead to the isolation or design of various polyamine derivatives possessing original mechanism of action towards cancer cells or microbes. In this latter case, during the last decades, the search and development of new antibiotics did not follow the rhythm of emergence of Multidrug resistant bacteria. Thus, the search for antimicrobial polyamine derivatives acting by membrane depolarization and/or integrity membrane disruption could constitute an efficient alternative to the well-known classes of drugs available. Furthermore, the finding of active molecules preferably with a weak antibiotic activity and that in combination with antibiotics could enhance or synergize the antimicrobial activity of inefficient antibiotics. In this case, the use of antibiotic adjuvants will 
lead to two beneficial outcomes: enhancement of the antimicrobial effect and reduction of the occurrence of mutations resulting in resistance. Finally, it is reasonable to envision that the continuous advances in the development of new and potent high-throughput technologies will definitively allow the discovery of new polyamine compounds possessing specific biological properties against cancer, degenerative diseases...

\section{References}

[1] Shah, P.; Swiatlo, E. A multifaceted role for polyamines in bacterial pathogens. Molecular Microbiology. 2008, 68, 4-16.

[2] Bienz, S.; Bisegger, P.; Guggisberg, A.; Hesse, M. Polyamine alkaloids. Nat. Prod. Rep. 2005, 22, 647-658.

[3] Huang, Y.; Pledgie, A.; Casero, R. A., Jr.; Davidson, N. E. Molecular mechanisms of polyamine analogs in cancer cells. Anti-Cancer Drugs. 2005, 16, 229-241.

[4] Wilson, D.; Nolan Matthew, J.; Tribolet, L.; Loukas, A.; Daly Norelle, L.; Boyle Glen, M.; Parsons Peter, G.; McIntyre, L.; Liddell Michael, J.; Smith Jennifer, J.; Rash Lachlan, D.; Rash Lachlan, D. The Aromatic Head Group of Spider Toxin Polyamines Influences Toxicity to Cancer Cells. Toxins (Basel). 2017, 9.

[5] Yerlikaya, A. Polyamines and S-adenosylmethionine decarboxylase. Turk Biyokim. Derg. 2004, 29, 208-214.

[6] Hussain, S. S.; Ali, M.; Ahmad, M.; Siddique, K. H. M. Polyamines: Natural and engineered abiotic and biotic stress tolerance in plants. Biotechnol. Adv. 2011, 29, 300311.

[7] Patocka, J.; Kuehn, G. D. Natural polyamines and their biological consequence in mammals. Acta Med. (Hradec Kralove, Czech Rep.). 2000, 43, 119-124.

[8] Kuznetsov, V. V.; Radyukina, N. L.; Shevyakova, N. I. Polyamines and stress: Biological roles, metabolism, and regulation. Russ. J. Plant Physiol. 2006, 53, 583-604.

[9] Peulen, O.; Deloyer, P.; Deville, C.; Dandrifosse, G. Polyamines in gut inflammation and allergy. Curr. Med. Chem. Anti-Inflammatory Anti-Allergy Agents. 2004, 3, 1-8.

[10] Raymond, J.; Blankenship, R. E. Horizontal gene transfer in eukaryotic algal evolution. Proc. Natl. Acad. Sci. USA 2003, 100, 7419-7420.

[11] Howarth, R. W. Nutrient limitation of net primary production in marine ecosystems. Ann. Rev. Ecol. Syst. 1988, 19, 89-110. 
[12] Armbrust, E. V. The life of diatoms in the world's oceans. Nature. 2009, 459, 185-192.

[13] Lu, X. Z., L.; Clevinger, C.; Liu, Q.; Hollibaugh, J.T.; Mou, X. Temporal dynamics and depth variations of dissolved free amino acids and polyamines in coastal seawater determined by high-performance liquid chromatography. Mar. Chem. 2014, 163, 36-44.

[14] Hamana, K.; Niitsu, M.; Hayashi, H. Occurrence of homospermidine and thermospermine as a cellular polyamine in unicellular chlorophyte and multicellular charophyte green algae. J. Gen. Appl. Microbiol. . 2013, 59, 313-319.

[15] Hosoya, R.; Hamana, K.; Niitsu, M.; Itoh, T. Polyamine analysis for chemotaxonomy of thermophilic eubacteria: Polyamine distribution profiles within the orders Aquificales, Thermotogales,

Thermodesulfobacteriales, Thermales, Thermoanaerobacteriales, Clostridiales and Bacillales. J. Gener. Appl. Microbiol. 2004, 50, 271-287.

[16] Kröger, N.; Deutzmann, R.; Bergsdorf, C.; Sumper, M. Species-specific polyamines from diatoms control silica morphology. Proc. Natl. Acad. Sci. USA 2000, 97, 14133-14138.

[17] Pawolski, D.; Heintze, C.; Mey, I.; Steinem, C.; Kröger, N. Reconstituting the formation of hierarchically porous silica patterns using diatom biomolecules. J. Struct. Biol. 2018, 204, 64-74.

[18] Sumper, M.; Brunner, E.; Lehmann, G. Biomineralization in diatoms: Characterization of novel polyamines associated with silica. FEBS Lett. . 2005, 579, 3765-3769.

[19] Burczyk, J.; Zych, M.; Ioannidis, N. E.; Kotzabasis, K. Polyamines in CellWalls of Chlorococcalean Microalgae. Z. Naturforsch. C. 2014, 69, 75-80.

[20] Casero, R. A. J.; Woster, P. M. Recent advances in the development of polyamine analogues as antitumor agents. J. Med. Chem. 2009, 52, 4551-4573.

[21] Nowotarski, S. L.; Woster, P. M.; Casero, R. A., Jr. Polyamines and cancer: Implications for chemotherapy and chemoprevention. Expert Rev. Mol. Med. 2013, 15, e3.

[22] Grishin, E.; Volkova, T.; Arsen'Ev, A.; Reshetova, O.; Onoprienko, V. Structuralfunctional characteristics of argiopine--the ion channel blockers from the spider Argiope lobata venom. Bioorg. Khim. 1986, 12, 1121-1124.

[23] Nelson Jared, K.; Frolund Sidsel, U.; Tikhonov Dennis, B.; Kristensen Anders, S.; Stromgaard, K. Synthesis and biological activity of argiotoxin 636 and analogues: selective antagonists for ionotropic glutamate receptors. Angew Chem Int Ed Engl. 2009, 48, 3087-3091. 
[24] Adams, M. E.; Carney, R. L.; Enderlin, F. E.; Fu, E. T.; Jarema, M. A.; Li, J. P.; Miller, C. A.; Schooley, D. A.; Shapiro, M. J.; Venema, V. J. Structures and biological activities of three synaptic antagonists from orb weaver spider venom. Biochem Biophys Res Commun. 1987, 148, 678-683.

[25] Shih, T. L.; Ruiz-Sanchez, J.; Mrozik, H. The total synthesis of argiopine (argiotoxin636). Tetrahedron Lett. 1987, 28, 6015-6018.

[26] Jasys, V. J.; Kelbaugh, P. R.; Nason, D. M.; Phillips, D.; Saccomano, N. A.; Volkmann, R. A. The total synthesis of argiotoxins 636, 659 and 673. Tetrahedron Lett. 1988, 29, 6223-6226.

[27] Blagbrough, I. S.; Moya, E. Total synthesis of polyamine amide spider toxin argiotoxin636 by a practical reductive alkylation strategy. Tetrahedron Lett. 1995, 36, 9393-9396.

[28] Budd, T.; Clinton, P.; Dell, A.; Duce, I. R.; Johnson, S. J.; Quicke, D. L.; Taylor, G. W.; Usherwood, P. N.; Usoh, G. Isolation and characterisation of glutamate receptor antagonists from venoms of orb-web spiders. Brain Res. 1988, 448, 30-39.

[29] Scott, R. H.; Thatcher, N. M.; Ayar, A.; Mitchell, S. J.; Pollock, J.; Gibson, M. T.; Duce, I. R.; Moya, E.; Blagbrough, I. S. Extracellular or intracellular application of argiotoxin636 has inhibitory actions on membrane excitability and voltage-activated currents in cultured rat sensory neurons. Neuropharmacology. 1998, 37, 1563-1578.

[30] Poulsen Mette, H.; Lucas, S.; Bach Tinna, B.; Barslund Anne, F.; Wenzler, C.; Jensen Christel, B.; Kristensen Anders, S.; Stromgaard, K. Structure-activity relationship studies of argiotoxins: selective and potent inhibitors of ionotropic glutamate receptors. J Med Chem. 2013, 56, 1171-1181.

[31] Draguhn, A.; Jahn, W.; Witzemann, V. Argiotoxin636 inhibits NMDA-activated ion channels expressed in Xenopus oocytes. Neurosci. Lett. 1991, 132, 187-190.

[32] Ashe, J. H.; Cox, C. L.; Adams, M. E. Argiotoxin-636 blocks excitatory synaptic transmission in rat hippocampal CA1 pyramidal neurons. Brain Res. 1989, 480, 234241.

[33] Herold, E. E.; Yaksh, T. L. Anesthesia and muscle relaxation with intrathecal injections of AR636 and AG489, two acylpolyamine spider toxins, in rat. Anesthesiology. 1992, $77,507-512$.

[34] Barslund, A. F.; Poulsen, M. H.; Bach, T. B.; Lucas, S.; Kristensen, A. S.; Stromgaard, K. Solid-phase synthesis and biological evaluation of Joro spider toxin-4 from Nephila clavata. J. Nat. Prod. 2011, 74, 483-486. 
[35] Verdoni, M.; Roudaut, H.; De Pomyers, H.; Gigmes, D.; Bertin, D.; Luis, J.; Bengeloune Abd, H.; Mabrouk, K. ArgTX-636, a polyamine isolated from spider venom: A novel class of melanogenesis inhibitors. Bioorg Med Chem. 2016, 24, 5685-5692.

[36] Tzouros, M.; Chesnov, S.; Bienz, S.; Hesse, M.; Bigler, L. New linear polyamine derivatives in spider venoms. Toxicon. 2005, 46, 350-354.

[37] Tzouros, M.; Chesnov, S.; Bigler, L.; Bienz, S. A template approach for the characterization of linear polyamines and derivatives in spider venom. European Journal of Mass Spectrometry. 2013, 19, 57-69.

[38] Palma, M. S.; Nakajima, T. A natural combinatorial chemistry strategy in acylpolyamine toxins from nephilinae orb-web spiders. Toxin Rev. 2005, 24, 209-234.

[39] Fukuyama, T.; Cheung, M.; Jow, C.-K.; Hidai, Y.; Kan, T. 2,4Dinitrobenzenesulfonamides: a simple and practical method for the preparation of a variety of secondary amines and diamines. Tetrahedron Lett. 1997, 38, 5831-5834.

[40] Nihei, K.-i.; Kato, M. J.; Yamane, T.; Palma, M. S.; Konno, K. An efficient and versatile synthesis of acylpolyamine spider toxins. Tennen Yuki Kagobutsu Toronkai Koen Yoshishu. 2001, 43rd, 515-520.

[41] Parks, T. N.; Mueller, A.; Artman, L. D.; Albensi, B.; Nemeth, E.; Jackson, H.; Jasys, V.; Saccomano, N.; Volkmann, R. Arylamine toxins from funnel-web spider (Agelenopsis aperta) venom antagonize $\mathrm{N}$-methyl-D-aspartate receptor function in mammalian brain. Journal of Biological Chemistry. 1991, 266, 21523-21529.

[42] Quistad, G. B.; Suwanrumpha, S.; Jarema, M. A.; Shapiro, M. J.; Skinner, W. S.; Jamieson, G. C.; Lui, A.; Fu, E. W. Structures of paralytic acylpolyamines from the spider Agelenopsis aperta. Biochem. Biophys. Res. Commun. 1990, 169, 51-56.

[43] Manov, N.; Tzouros, M.; Chesnov, S.; Bigler, L.; Bienz, S. Solid-phase synthesis of polyamine spider toxins and correlation with the natural products by HPLC-MS/MS. Helv. Chim. Acta. 2002, 85, 2827-2846.

[44] Kan, T.; Fukuyama, T. Ns strategies: a highly versatile synthetic method for amines. Chem. Commun. (Cambridge, U. K.). 2004, 353-359.

[45] Jasys, V. J.; Kelbaugh, P. R.; Nason, D. M.; Phillips, D.; Rosnack, K. J.; Saccomano, N. A.; Stroh, J. G.; Volkmann, R. A.; Forman, J. T. Novel quaternary ammonium saltcontaining polyamines from the Agelenopsis aperta funnel-web spider. J. Org. Chem. 1992, 57, 1814-1820. 
[46] Toki, T.; Yasuhara, T.; Aramaki, Y.; Hashimoto, Y.; Shudo, K.; Kawai, N.; Nakajima, T. Molecular structures of spider toxins (JSTX-1, 2, 3 and 4) in the venom of Nephila clavata L. Koch. Eisei Dobutsu. 1990, 41, 9-14.

[47] Bruce, M.; Bukownik, R.; Eldefrawi, A. T.; Eldeerawi, M. E.; Goodnow, R., Jr.; Kallimopoulos, T.; Konno, K.; Nakanishi, K.; Niwa, M.; Usherwood, P. N. R. Structure-activity relationships of analogs of the wasp toxin philanthotoxin: noncompetitive antagonists of quisqualate receptors. Toxicon. 1990, 28, 1333-1346.

[48] Franzyk, H.; Grzeskowiak John, W.; Tikhonov Denis, B.; Jaroszewski Jerzy, W.; Mellor Ian, R. The effects of conformational constraints in the polyamine moiety of philanthotoxins on AMPAR inhibition. ChemMedChem. 2014, 9, 1725-1731.

[49] Fedorov, N. B.; Screbitsky, V. G.; Reymann, K. G. Effects of philanthotoxin-343 on CA1 pyramidal neurons of rat hippocampus in vitro. Eur J Pharmacol. 1992, 228, 201206.

[50] Kachel, H. S.; Franzyk, H.; Mellor, I. R. Philanthotoxin Analogues That Selectively Inhibit Ganglionic Nicotinic Acetylcholine Receptors with Exceptional Potency. J. Med. Chem. 2019, 62, 6214-6222.

[51] Eldefrawi, A. T.; Eldefrawi, M. E.; Konno, K.; Mansour, N. A.; Nakanishi, K.; Oltz, E.; Usherwood, P. N. Structure and synthesis of a potent glutamate receptor antagonist in wasp venom. Proc Natl Acad Sci U S A. 1988, 85, 4910-4913.

[52] Nakanishi, K.; Goodnow, R.; Konno, K.; Niwa, M.; Bukownik, R.; Kallimopoulos, T. A.; Usherwood, P.; Eldefrawi, A. T.; Eldefrawi, M. E. Philanthotoxin-433 (PhTX-433), a non-competitive glutamate receptor inhibitor. Pure Appl. Chem. 1990, 62, 1223-1230.

[53] Goodnow, R., Jr.; Konno, K.; Niwa, M.; Kallimopoulos, T.; Bukownik, R.; Lenares, D.; Nakanishi, K. Synthesis of glutamate receptor antagonist philanthotoxin-433 (PhTX433) and its analogs. Tetrahedron. 1990, 46, 3267-3286.

[54] Wang, F.; Manku, S.; Hall, D. G. Solid Phase Syntheses of Polyamine Toxins HO-416b and PhTX-433. Use of an Efficient Polyamide Reduction Strategy That Facilitates Access to Branched Analogues. Org. Lett. 2000, 2, 1581-1583.

[55] Chhabra, S. R.; Khan, A. N.; Bycroft, B. W. Solid-phase synthesis of polyamines using a Dde-linker: philanthotoxin-4.3.3 via an on-resin Mitsunobu reaction. Tetrahedron Lett. 2000, 41, 1099-1102.

[56] Andersen, T. F.; Stromgaard, K. Synthesis of polyamines and polyamine toxins. An improved alkylation procedure. Tetrahedron Lett. 2004, 45, 7929-7933. 
[57] Stromgaard, K.; Andersen, K.; Ruhland, T.; Krogsgaard-Larsen, P.; Jaroszewski, J. W. A versatile method for solid-phase synthesis of polyamines: neuroactive polyamine toxins as example. Synthesis. 2001, 877-884.

[58] Stromgaard, K.; Piazzi, L.; Olsen Christian, A.; Franzyk, H.; Jaroszewski Jerzy, W. Protolytic properties of polyamine wasp toxin analogues studied by 13C NMR spectroscopy. Magn Reson Chem. 2006, 44, 1013-1022.

[59] Choi, S. K.; Kalivretenos, A. G.; Usherwood, P. N.; Nakanishi, K. Labeling studies of photolabile philanthotoxins with nicotinic acetylcholine receptors: mode of interaction between toxin and receptor. Chem Biol. 1995, 2, 23-32.

[60] Andersen Trine, F.; Vogensen Stine, B.; Jensen Lars, S.; Knapp Kolja, M.; Stromgaard, K. Design and synthesis of labeled analogs of PhTX-56, a potent and selective AMPA receptor antagonist. Bioorg Med Chem. 2005, 13, 5104-5112.

[61] Jones, M. G.; Lodge, D. Comparison of some arthropod toxins and toxin fragments as antagonists of excitatory amino acid-induced excitation of rat spinal neurons. Eur. $J$. Pharmacol. 1991, 204, 203-209.

[62] Jensen Lars, S.; Bolcho, U.; Egebjerg, J.; Stromgaard, K. Design, synthesis, and pharmacological characterization of polyamine toxin derivatives: potent ligands for the pore-forming region of AMPA receptors. ChemMedChem. 2006, 1, 419-428.

[63] Basle, A.; Delcour, A. H. Effect of Two Polyamine Toxins on the Bacterial Porin OmpF. Biochem. Biophys. Res. Commun. 2001, 285, 550-554.

[64] Bixel, M. G.; Krauss, M.; Liu, Y.; Bolognesi, M. L.; Rosini, M.; Mellor, I. S.; Usherwood, P. N.; Melchiorre, C.; Nakanishi, K.; Hucho, F. Structure-activity relationship and site of binding of polyamine derivatives at the nicotinic acetylcholine receptor. Eur J Biochem. 2000, 267, 110-120.

[65] Froelund, S.; Bella, A.; Kristensen, A. S.; Ziegler, H. L.; Witt, M.; Olsen, C. A.; Stroemgaard, K.; Franzyk, H.; Jaroszewski, J. W. Assessment of structurally diverse philanthotoxin analogues for inhibitory activity on ionotropic glutamate receptor subtypes: Discovery of nanomolar, nonselective, and use-dependent antagonists. J. Med. Chem. 2010, 53, 7441-7451.

[66] Kachel Hamid, S.; Patel Rohit, N.; Mellor Ian, R.; Franzyk, H. Block of nicotinic acetylcholine receptors by philanthotoxins is strongly dependent on their subunit composition. Sci Rep. 2016, 6, 38116.

[67] Kromann, H.; Krikstolaityte, S.; Andersen, A. J.; Andersen, K.; Krogsgaard-Larsen, P.; Jaroszewski, J. W.; Egebjerg, J.; Stromgaard, K. Solid-Phase Synthesis of Polyamine 
Toxin Analogues: Potent and Selective Antagonists of Ca2+-Permeable AMPA Receptors. J. Med. Chem. 2002, 45, 5745-5754.

[68] Stromgaard, K.; Mellor Ian, R.; Andersen, K.; Neagoe, I.; Pluteanu, F.; Usherwood Peter, N. R.; Krogsgaard-Larsen, P.; Jaroszewski Jerzy, W. Solid-phase synthesis and pharmacological evaluation of analogues of PhTX-12-A potent and selective nicotinic acetylcholine receptor antagonist. Bioorg Med Chem Lett. 2002, 12, 1159-1162.

[69] Stromgaard, K.; Bjornsdottir, I.; Andersen, K.; Brierley, M. J.; Rizoli, S.; Eldursi, N.; Mellor, I. R.; Usherwood, P. N.; Hansen, S. H.; Krogsgaard-Larsen, P.; Jaroszewski, J. W. Solid phase synthesis and biological evaluation of enantiomerically pure wasp toxin analogues PhTX-343 and PhTX-12. Chirality. 2000, 12, 93-102.

[70] Rao, M. N.; Shinnar, A. E.; Noecker, L. A.; Chao, T. L.; Feibush, B.; Snyder, B.; Sharkansky, I.; Sarkahian, A.; Zhang, X.; Jones, S. R.; Kinney, W. A.; Zasloff, M. Aminosterols from the dogfish shark Squalus acanthias. J. Nat. Prod. 2000, 63, 631635.

[71] Yun, S.-S.; Li, W. Identification of squalamine in the plasma membrane of white blood cells in the sea lamprey, Petromyzon marinus. J. Lipid Res. 2007, 48, 2579-2586.

[72] Brunel Jean, M.; Salmi, C.; Loncle, C.; Vidal, N.; Letourneux, Y. Squalamine: a polyvalent drug of the future? Curr Cancer Drug Targets. 2005, 5, 267-272.

[73] Ding, B.; Guan, Q.; Walsh, J. P.; Boswell, J. S.; Winter, T. W.; Winter, E. S.; Boyd, S. S.; Li, C.; Savage, P. B. Correlation of the antibacterial activities of cationic peptide antibiotics and cationic steroid antibiotics. J. Med. Chem. 2002, 45, 663-669.

[74] Savage Paul, B.; Li, C.; Taotafa, U.; Ding, B.; Guan, Q. Antibacterial properties of cationic steroid antibiotics. FEMS Microbiol Lett. 2002, 217, 1-7.

[75] Moriarty, R. M.; Tuladhar, S. M.; Guo, L.; Wehrli, S. Synthesis of squalamine. A steroidal antibiotic from the shark. Tetrahedron Lett. 1994, 35, 8103-8106.

[76] Pechulis, A. D.; Bellevue, F. H., III; Cioffi, C. L.; Trapp, S. G.; Fojtik, J. P.; McKitty, A. A.; Kinney, W. A.; Frye, L. L. Synthesis of $24 \xi$-Squalamine, an Anti-Infective Steroidal Polyamine. J. Org. Chem. 1995, 60, 5121-5126.

[77] Moriarty, R. M.; Enache, L. A.; Kinney, W. A.; Allen, C. S.; Canary, J. W.; Tuladhar, S. M.; Guo, L. Stereoselective synthesis of squalamine dessulfate. Tetrahedron Lett. 1995, $36,5139-5142$.

[78] Zhang, X.; Rao, M. N.; Jones, S. R.; Shao, B.; Feibush, P.; McGuigan, M.; Tzodikov, N.; Feibush, B.; Sharkansky, I.; Snyder, B.; Mallis, L. M.; Sarkahian, A.; Wilder, S.; Turse, J. E.; Kinney, W. A.; Kjrsgaard, H. J.; Michalak, R. S. Synthesis of Squalamine 
Utilizing a Readily Accessible Spermidine Equivalent. J. Org. Chem. 1998, 63, 85998603.

[79] Jones, S. R.; Selinsky, B. S.; Rao, M. N.; Zhang, X.; Kinney, W. A.; Tham, F. S. Efficient Route to 7 $\alpha$-(Benzoyloxy)-3-dioxolane Cholestan-24(R)-ol, a Key Intermediate in the Synthesis of Squalamine. J. Org. Chem. 1998, 63, 3786-3789.

[80] Kinney, W. A.; Zhang, X.; Williams, J. I.; Johnston, S.; Michalak, R. S.; Deshpande, M.; Dostal, L.; Rosazza, J. P. N. A Short Formal Synthesis of Squalamine from a Microbial Metabolite. Org. Lett. 2000, 2, 2921-2922.

[81] Zhou, X.-D.; Cai, F.; Zhou, W.-S. A stereoselective synthesis of squalamine. Tetrahedron. 2002, 58, 10293-10299.

[82] Zhou, X. D.; Cai, F.; Zhou, W. S. A new highly stereoselective construction of the sidechain of squalamine through improved Sharpless catalytic asymmetric dihydroxylation. Tetrahedron Lett. 2001, 42, 2537-2539.

[83] Okumura, K.; Nakamura, Y.; Takeuchi, S.; Kato, I.; Fujimoto, Y.; Ikekawa, N. Formal synthesis of squalamine from desmosterol. Chem. Pharm. Bull. 2003, 51, 1177-1182.

[84] Zhang, D.-H.; Cai, F.; Zhou, X.-D.; Zhou, W.-S. A Concise and Stereoselective Synthesis of Squalamine. Org. Lett. 2003, 5, 3257-3259.

[85] Zhang, D.-H.; Cai, F.; Zhou, X.-D.; Zhou, W.-S. A short and highly stereoselective synthesis of squalamine from methyl chenodeoxycholanate. Chin. J. Chem. 2005, 23, 176-181.

[86] Zhou, S.; Zheng, Y.; Yang, B.; Zhong, J.; Shi, H. Study on synthesis of key squalamine intermediate 7 $\alpha$, 24R-dihydroxy-5 $\alpha$-cholestan-3-one. Steroids. 2019, 151, 108472pp.

[87] Alhanout, K.; Rolain, J. M.; Brunel, J. M. Squalamine as an example of a new potent antimicrobial agents class: a critical review. Curr. Med. Chem. 2010, 17, 3909-3917.

[88] Brycki, B.; Koenig, H.; Pospieszny, T. Quaternary alkylammonium conjugates of steroids: synthesis, molecular structure, and biological studies. Molecules. 2015, 20, 20887-20900.

[89] Alhanout, K.; Brunel, J.-M.; Raoult, D.; Rolain, J.-M. In vitro antibacterial activity of aminosterols against multidrug-resistant bacteria from patients with cystic fibrosis. $J$. Antimicrob. Chemother. 2009, 64, 810-814.

[90] Salmi, C.; Loncle, C.; Vidal, N.; Letourneux, Y.; Fantini, J.; Maresca, M.; Taieb, N.; Pages, J.-M.; Brunel Jean, M. Squalamine: an appropriate strategy against the emergence of multidrug resistant gram-negative bacteria? PLoS One. 2008, 3, e2765. 
[91] Coulibaly, O.; Alhanout, K.; L'Ollivier, C.; Brunel, J.-M.; Thera, M. A.; Djimde, A. A.; Doumbo, O. K.; Piarroux, R.; Ranque, S. In vitro activity of aminosterols against dermatophytes. Med. Mycol. 2013, 51, 309-312.

[92] Alhanout, K.; Brunel Jean, M.; Ranque, S.; Rolain Jean, M. In vitro antifungal activity of aminosterols against moulds isolated from cystic fibrosis patients. J Antimicrob Chemother. 2010, 65, 1307-1309.

[93] Alhanout, K.; Malesinki, S.; Vidal, N.; Peyrot, V.; Rolain Jean, M.; Brunel Jean, M. New insights into the antibacterial mechanism of action of squalamine. J Antimicrob Chemother. 2010, 65, 1688-1693.

[94] Selinsky, B. S.; Zhou, Z.; Fojtik, K. G.; Jones, S. R.; Dollahon, N. R.; Shinnar, A. E. The aminosterol antibiotic squalamine permeabilizes large unilamellar phospholipid vesicles. Biochim. Biophys. Acta, Biomembr. 1998, 1370, 218-234.

[95] Selinsky, B. S.; Smith, R.; Frangiosi, A.; Vonbaur, B.; Pedersen, L. Squalamine is not a proton ionophore. Biochim. Biophys. Acta, Biomembr. 2000, 1464, 135-141.

[96] Di Pasquale, E.; Salmi-Smail, C.; Brunel, J.-M.; Sanchez, P.; Fantini, J.; Maresca, M. Biophysical studies of the interaction of squalamine and other cationic amphiphilic molecules with bacterial and eukaryotic membranes: importance of the distribution coefficient in membrane selectivity. Chem. Phys. Lipids. 2010, 163, 131-140.

[97] Russo, T. A.; Mylotte, D. Expression of the K54 and O4 specific antigen has opposite effects on the bactericidal activity of squalamine against an extraintestinal isolate of Escherichia coli. FEMS Microbiol. Lett. 1998, 162, 311-315.

[98] Djouhri-Bouktab, L.; Alhanout, K.; Andrieu, V.; Raoult, D.; Rolain, J. M.; Brunel, J. M. Squalamine ointment for Staphylococcus aureus skin decolonization in a mouse model. J. Antimicrob. Chemother. 2011, 66, 1306-1310.

[99] Nicol, M.; Jouenne, T.; Mlouka Mohamed Amine, B.; Di Martino, P.; Berthe, T.; Brunel, J.-M.; De, E. Anti-persister activity of squalamine against Acinetobacter baumannii. Int J Antimicrob Agents. 2019, 53, 337-342.

[100] Walker, B. T.; Houston, T. A. Squalamine and its derivatives as potential antitubercular compounds. Tuberculosis (Oxford, U. K.). 2013, 93, 102-103.

[101] Asmar, S.; Drancourt, M. Chlorhexidine decontamination of sputum for culturing Mycobacterium tuberculosis. BMC Microbiol. 2015, 15, 1-6.

[102] Dridi, B.; Fardeau, M.-L.; Ollivier, B.; Raoult, D.; Drancourt, M. The antimicrobial resistance pattern of cultured human methanogens reflects the unique phylogenetic position of archaea. J. Antimicrob. Chemother. 2011, 66, 2038-2044. 
[103] Khelaifia, S.; Brunel Jean, M.; Michel Jean, B.; Drancourt, M. In-vitro archaeacidal activity of biocides against human-associated archaea. PLoS One. 2013, 8, e62738.

[104] Khelaifia, S.; Drancourt, M. Susceptibility of archaea to antimicrobial agents: applications to clinical microbiology. Clin. Microbiol. Infect. 2012, 18, 841-848.

[105] Lavigne, J.-P.; Brunel, J.-M.; Chevalier, J.; Pages, J.-M. Squalamine, an original chemosensitizer to combat antibiotic-resistant Gram-negative bacteria. J. Antimicrob. Chemother. 2010, 65, 799-801.

[106] Cushnie, T. P. T.; Cushnie, B.; Lamb Andrew, J. Alkaloids: an overview of their antibacterial, antibiotic-enhancing and antivirulence activities. Int $J$ Antimicrob Agents. 2014, 44, 377-386.

[107] Alhanout, K.; Djouhri, L.; Vidal, N.; Brunel Jean, M.; Piarroux, R.; Ranque, S. In vitro activity of aminosterols against yeasts involved in blood stream infections. Med Mycol. 2011, 49, 121-125.

[108] Djouhri-Bouktab, L.; Alhanout, K.; Andrieu, V.; Stremler, N.; Dubus, J. C.; Raoult, D.; Rolain, J. M.; Brunel, J. M. Soluble squalamine tablets for the rapid disinfection of home nebulizers of cystic fibrosis patients. J. Cystic Fibrosis. 2012, 11, 555-559.

[109] Hraiech, S.; Bregeon, F.; Brunel, J.-M.; Rolain, J.-M.; Lepidi, H.; Andrieu, V.; Raoult, D.; Papazian, L.; Roch, A. Antibacterial efficacy of inhaled squalamine in a rat model of chronic Pseudomonas aeruginosa pneumonia. J. Antimicrob. Chemother. 2012, 67, $2452-2458$

[110] Sakr, A.; Bregeon, F.; Rolain, J.-M.; Blin, O. Staphylococcus aureus nasal decolonization strategies: a review. Expert Rev. Anti-Infect. Ther. 2019, 17, 327-340.

[111] Coulibaly, O.; Thera, M. A.; Kone, A. K.; Siaka, G.; Traore, P.; Djimde, A. A.; Brunel, J.-M.; Gaudart, J.; Piarroux, R.; Doumbo, O. K.; Ranque, S. A Double-Blind Randomized Placebo-Controlled Clinical Trial of Squalamine Ointment for tinea capitis Treatment. Mycopathologia. 2015, 179, 187-193.

[112] Alhanout, K.; Brunel Jean, M.; Dubus Jean, C.; Rolain Jean, M.; Andrieu, V. Suitability of a new antimicrobial aminosterol formulation for aerosol delivery in cystic fibrosis. $J$ Antimicrob Chemother. 2011, 66, 2797-2800.

[113] Kikuchi, K.; Bernard, E. M.; Sadownik, A.; Regen, S. L.; Armstrong, D. Antimicrobial activities of squalamine mimics. Antimicrob. Agents Chemother. 1997, 41, 1433-1438.

[114] Wang, H.; Naghavi, M.; Allen, C.; Barber, R. M.; Bhutta, Z. A.; Carter, A.; Casey, D. C.; Charlson, F. J.; Chen, A. Z.; Coates, M. M. Global, regional, and national life expectancy, all-cause mortality, and cause-specific mortality for 249 causes of death, 
1980-2015: a systematic analysis for the Global Burden of Disease Study 2015. Lancet. 2016, 388, 1459-1544.

[115] Williams, J. I.; Weitman, S.; Gonzalez, C. M.; Jundt, C. H.; Marty, J.; Stringer, S. D.; Holroyd, K. J.; McLane, M. P.; Chen, Q.; Zasloff, M.; Von Hoff, D. D. Squalamine treatment of human tumors in nu/nu mice enhances platinum-based chemotherapies. Clin Cancer Res. 2001, 7, 724-733.

[116] Sills, A. K., Jr.; Williams, J. I.; Tyler, B. M.; Epstein, D. S.; Sipos, E. P.; Davis, J. D.; McLane, M. P.; Pitchford, S.; Cheshire, K.; Gannon, F. H.; Kinney, W. A.; Chao, T. L.; Donowitz, M.; Laterra, J.; Zasloff, M.; Brem, H. Squalamine inhibits angiogenesis and solid tumor growth in vivo and perturbs embryonic vasculature. Cancer Res. 1998, 58, 2784-2792.

[117] Akhter, S.; Nath, S. K.; Tse, C. M.; Williams, J.; Zasloff, M.; Donowitz, M. Squalamine, a novel cationic steroid, specifically inhibits the brush-border $\mathrm{Na}+\mathrm{H}+$ exchanger isoform NHE3. Am. J. Physiol. 1999, 276, C136-C144.

[118] Donowitz, M.; Janecki, A.; Akhter, S.; Cavet, M. E.; Sanchez, F.; Lamprecht, G.; Zizak, M.; Kwon, W. L.; Khurana, S.; Yun, C. H.; Tse, C. M. Short-term regulation of NHE3 by EGF and protein kinase $\mathrm{C}$ but not protein kinase $\mathrm{A}$ involves vesicle trafficking in epithelial cells and fibroblasts. Ann N Y Acad Sci. 2000, 915, 30-42.

[119] Hao, D.; Hammond, L. A.; Eckhardt, S. G.; Patnaik, A.; Takimoto, C. H.; Schwartz, G. H.; Goetz, A. D.; Tolcher, A. W.; McCreery, H. A.; Mamun, K.; Williams, J. I.; Holroyd, K. J.; Rowinsky, E. K. A Phase I and Pharmacokinetic Study of Squalamine, an Aminosterol Angiogenesis Inhibitor. Clin. Cancer Res. 2003, 9, 2465-2471.

[120] Li, D.; Williams, J. I.; Pietras, R. J. Squalamine and cisplatin block angiogenesis and growth of human ovarian cancer cells with or without HER-2 gene overexpression. Oncogene. 2002, 21, 2805-2814.

[121] Schiller, J. H.; Bittner, G. Potentiation of platinum antitumor effects in human lung tumor xenografts by the angiogenesis inhibitor squalamine: effects on tumor neovascularization. Clin. Cancer Res. 1999, 5, 4287-4294.

[122] Sokoloff Mitchell, H.; Rinker-Schaeffer Carrie, W.; Chung Leland, W. K.; Brendler Charles, B. Adjunctive therapy for men with high risk localized and locally advanced prostate cancer: targeting disseminated tumor cells. J Urol. 2004, 172, 2539-2544.

[123] Marquez-Garban, D. C.; Gorrin-Rivas, M.; Chen, H.-W.; Sterling, C., Jr.; Elashoff, D.; Hamilton, N.; Pietras, R. J. Squalamine blocks tumor-associated angiogenesis and 
growth of human breast cancer cells with or without HER-2/neu overexpression. Cancer Lett. (N. Y., NY, U. S.). 2019, 449, 66-75.

[124] Yin, M.; Gentili, C.; Koyama, E.; Zasloff, M.; Pacifici, M. Antiangiogenic treatment delays chondrocyte maturation and bone formation during limb skeletogenesis. J. Bone Miner. Res. 2002, 17, 56-65.

[125] Bhargava, P.; Marshall, J. L.; Dahut, W.; Rizvi, N.; Trocky, N.; Williams, J. I.; Hait, H.; Song, S.; Holroyd, K. J.; Hawkins, M. J. A Phase I and pharmacokinetic study of squalamine, a novel antiangiogenic agent, in patients with advanced cancers. Clin. Cancer Res. 2001, 7, 3912-3919.

[126] Herbst, R. S.; Hammond, L. A.; Carbone, D. P.; Tran, H. T.; Holroyd, K. J.; Desai, A.; Williams, J. I.; Bekele, B. N.; Hait, H.; Allgood, V.; Solomon, S.; Schiller, J. H. A Phase I/IIA Trial of Continuous Five-Day Infusion of Squalamine Lactate (MSI-1256F) Plus Carboplatin and Paclitaxel in Patients with Advanced Non-Small Cell Lung Cancer. Clin. Cancer Res. 2003, 9, 4108-4115.

[127] Pietras Richard, J.; Weinberg Olga, K. Antiangiogenic Steroids in Human Cancer Therapy. Evid Based Complement Alternat Med. 2005, 2, 49-57.

[128] Sridhar Srikala, S.; Shepherd Frances, A. Targeting angiogenesis: a review of angiogenesis inhibitors in the treatment of lung cancer. Lung Cancer. 2003, 42 Suppl 1, S81-91.

[129] Emerson, M. V.; Lauer, A. K. Current and emerging therapies for the treatment of agerelated macular degeneration. Clin. Ophthalmol. 2008, 2, 377-388.

[130] Higgins, R. D.; Yan, Y.; Geng, Y.; Zasloff, M.; Williams, J. I. Regression of Retinopathy by Squalamine in a Mouse Model. Pediatr. Res. 2004, 56, 144-149.

[131] Higgins, R. D.; Sanders, R. J.; Yan, Y.; Zasloff, M.; Williams, J. I. Squalamine improves retinal neovascularization. Invest Ophthalmol Vis Sci. 2000, 41, 1507-1512.

[132] Genaidy, M.; Kazi Abdul, A.; Peyman Gholam, A.; Passos-Machado, E.; Farahat Hassan, G.; Williams Jon, I.; Holroyd Kenneth, J.; Blake Diane, A. Effect of squalamine on iris neovascularization in monkeys. Retina. 2002, 22, 772-778.

[133] Ciulla Thomas, A.; Criswell Mark, H.; Danis Ronald, P.; Williams Jon, I.; McLane Michael, P.; Holroyd Kenneth, J. Squalamine lactate reduces choroidal neovascularization in a laser-injury model in the rat. Retina. 2003, 23, 808-814.

[134] Ciulla, T.; Oliver, A.; Gast, M. J. Squalamine lactate for the treatment of age-related macular degeneration. Expert Rev. Ophthalmol. 2007, 2, 165-175. 
[135] Chakravarthy, U.; Soubrane, G.; Bandello, F.; Chong, V.; Creuzot-Garcher, C.; Dimitrakos, S. A., 2nd; Korobelnik, J. F.; Larsen, M.; Mones, J.; Pauleikhoff, D.; Pournaras, C. J.; Staurenghi, G.; Virgili, G.; Wolf, S. Evolving European guidance on the medical management of neovascular age related macular degeneration. $\mathrm{Br} J$ Ophthalmol. 2006, 90, 1188-1196.

[136] Michels, S.; Schmidt-Erfurth, U.; Rosenfeld Philip, J. Promising new treatments for neovascular age-related macular degeneration. Expert Opin Investig Drugs. 2006, 15, 779-793.

[137] Emerson, M. V.; Lauer, A. K. Emerging therapies for the treatment of neovascular agerelated macular degeneration and diabetic macular edema. BioDrugs. 2007, 21, 245257.

[138] Pecen Paula, E.; Kaiser Peter, K. Current phase 1/2 research for neovascular age-related macular degeneration. Curr Opin Ophthalmol. 2015, 26, 188-193.

[139] Wroblewski John, J.; Hu Allen, Y. Topical Squalamine 0.2\% and Intravitreal Ranibizumab $0.5 \mathrm{mg}$ as Combination Therapy for Macular Edema Due to Branch and Central Retinal Vein Occlusion: An Open-Label, Randomized Study. Ophthalmic Surg Lasers Imaging Retina. 2016, 47, 914-923.

[140] Hussain Rehan, M.; Ciulla Thomas, A.; Ciulla Thomas, A. Emerging vascular endothelial growth factor antagonists to treat neovascular age-related macular degeneration. Expert Opin Emerg Drugs. 2017, 22, 235-246.

[141] Al-Khersan, H.; Hussain Rehan, M.; Ciulla Thomas, A.; Ciulla Thomas, A.; Ciulla Thomas, A.; Dugel Pravin, U.; Dugel Pravin, U. Innovative therapies for neovascular age-related macular degeneration. Expert Opin Pharmacother. 2019, 20, 1879-1891.

[142] Bhatt, S.; Gething, P. W.; Brady, O. J.; Messina, J. P.; Farlow, A. W.; Moyes, C. L.; Drake, J. M.; Brownstein, J. S.; Hoen, A. G.; Sankoh, O. The global distribution and burden of dengue. Nature. 2013, 496, 504-507.

[143] Trépo, C.; Chan, H. L.; Lok, A. Hepatitis B virus infection. Lancet. 2014, 384, 2053 2063.

[144] Zasloff, M.; Adams, A. P.; Beckerman, B.; Campbell, A.; Han, Z.; Luijten, E.; Meza, I.; Julander, J.; Mishr, A.; Qu, W.; Taylor, J. M.; Weaver, S. C.; Wong, G. C. L. Squalamine as a broad-spectrum systemic antiviral agent with therapeutic potential. Proc. Natl. Acad. Sci. U. S. A. 2011, 108, 15978-15983, S15978/15971-S15978/15976.

[145] Mao, X.; Ou, M. T.; Karuppagounder, S. S.; Kam, T.-I.; Yin, X.; Xiong, Y.; Ge, P.; Umanah, G. E.; Brahmachari, S.; Shin, J.-H. Pathological $\alpha$-synuclein transmission 
initiated by binding lymphocyte-activation gene 3. Science (New York, N.Y.). 2016, 353, aah3374.

[146] [2131] International, A. s. D. Rapport Mondial Alzheimer 2015. 2015.

[147] Pineda, A.; Burre, J. Modulating membrane binding of $\alpha$-synuclein as a therapeutic strategy. Proc. Natl. Acad. Sci. U. S. A. 2017, 114, 1223-1225.

[148] Wirths, O.; Bayer, T. A. $\alpha$-Synuclein, A $\beta$ and Alzheimer's disease. Prog. Neuropsychopharmacol. Biol. Psychiatry. 2003, 27, 103-108.

[149] Perni, M.; Galvagnion, C.; Maltsev, A.; Meisl, G.; Müller, M. B.; Challa, P. K.; Kirkegaard, J. B.; Flagmeier, P.; Cohen, S. I.; Cascella, R. A natural product inhibits the initiation of $\alpha$-synuclein aggregation and suppresses its toxicity. Proceedings of the National Academy of Sciences. 2017, 114, E1009-E1017.

[150] Alhanout, K.; Giorgio, C. D.; Meo, M. D.; Brunel, J. M. Non-Genotoxic Assessment of a Natural Antimicrobial Agent: Squalamine. Anti-Infect. Agents. 2014, 12, 75-79.

[151] Li, A. C.; Sabo, A. M.; McCormick, T.; Johnston, S. M. Quantitative analysis of squalamine, a self-ionization-suppressing aminosterol sulfate, in human plasma by LCMS/MS. J. Pharm. Biomed. Anal. 2004, 34, 631-641.

[152] Li, C.-J.; Kari, U. P.; Noecker Lincoln, A.; Jones Stephen, R.; Sabo Andrew, M.; McCormick Timothy, J.; Johnston Sean, M. Determination of degradation products of squalamine lactate using LC/MS. J Pharm Biomed Anal. 2003, 32, 85-96.

[153] Zasloff, M.; Williams, J. I.; Chen, Q.; Anderson, M.; Maeder, T.; Holroyd, K.; Jones, S.; Kinney, W.; Cheshire, K.; McLane, M. A spermine-coupled cholesterol metabolite from the shark with potent appetite suppressant and antidiabetic properties. Int. J. Obes. 2001, 25, 689-697.

[154] Ahima Rexford, S.; Patel Hiralben, R.; Takahashi, N.; Qi, Y.; Hileman Stanley, M.; Zasloff Michael, A. Appetite suppression and weight reduction by a centrally active aminosterol. Diabetes. 2002, 51, 2099-2104.

[155] Qin, Z.; Pandey, N. R.; Zhou, X.; Stewart, C. A.; Hari, A.; Huang, H.; Stewart, A. F. R.; Brunel, J. M.; Chen, H.-H. Functional properties of Claramine: A novel PTP1B inhibitor and insulin-mimetic compound. Biochem. Biophys. Res. Commun. 2015, 458, 21-27.

[156] Roitman Mitchell, F.; Wescott, S.; Cone Jackson, J.; McLane Michael, P.; Wolfe Henry, R. MSI-1436 reduces acute food intake without affecting dopamine transporter activity. Pharmacol Biochem Behav. 2010, 97, 138-143. 
[157] Lantz Kristen, A.; Hart Susan, G. E.; Planey Sonia, L.; Roitman Mitchell, F.; RuizWhite Inez, A.; Wolfe Henry, R.; McLane Michael, P. Inhibition of PTP1B by trodusquemine (MSI-1436) causes fat-specific weight loss in diet-induced obese mice. Obesity (Silver Spring). 2010, 18, 1516-1523.

[158] Vintonyak, V. V.; Waldmann, H.; Rauh, D. Using small molecules to target protein phosphatases. Bioorg. Med. Chem. 2011, 19, 2145-2155.

[159] Krishnan, N.; Konidaris, K. F.; Gasser, G.; Tonks, N. K. A potent, selective, and orally bioavailable inhibitor of the protein-tyrosine phosphatase PTP1B improves insulin and leptin signaling in animal models. J. Biol. Chem. 2018, 293, 1517-1525.

[160] Krishnan, N.; Koveal, D.; Miller, D. H.; Xue, B.; Akshinthala, S. D.; Kragelj, J.; Jensen, M. R.; Gauss, C.-M.; Page, R.; Blackledge, M.; Muthuswamy, S. K.; Peti, W.; Tonks, N. K. Targeting the disordered $\mathrm{C}$ terminus of PTP1B with an allosteric inhibitor. Nat. Chem. Biol. 2014, 10, 558-566.

[161] Pandey, N. R.; Zhou, X.; Zaman, T.; Cruz, S. A.; Qin, Z.; Lu, M.; Keyhanian, K.; Brunel, J. M.; Stewart, A. F. R.; Chen, H.-H. LMO4 is required to maintain hypothalamic insulin signaling. Biochem. Biophys. Res. Commun. 2014, 450, 666-672.

[162] Thompson, D.; Morrice, N.; Grant, L.; Le Sommer, S.; Lees Emma, K.; Mody, N.; Wilson Heather, M.; Delibegovic, M. Pharmacological inhibition of protein tyrosine phosphatase $1 \mathrm{~B}$ protects against atherosclerotic plaque formation in the LDLR(-/-) mouse model of atherosclerosis. Clin Sci (Lond). 2017, 131, 2489-2501.

[163] Thiebaut, P.-A.; Delile, E.; Coquerel, D.; Renet, S.; Tamion, F.; Brunel, J.-M.; Richard, V. Protein tyrosine phosphatase 1B regulates endothelial endoplasmic reticulum stress; role in endothelial dysfunction. Vascul Pharmacol. 2018, 109, 36-44.

[164] Younossi, Z. M.; Stepanova, M.; Afendy, M.; Fang, Y.; Younossi, Y.; Mir, H.; Srishord, M. Changes in the prevalence of the most common causes of chronic liver diseases in the United States from 1988 to 2008. Clin. Gastroenterol. Hepatol. 2011, 9 , 524-530.

[165] Takahashi, N.; Qi, Y.; Patel, H. R.; Ahima, R. S. A novel aminosterol reverses diabetes and fatty liver disease in obese mice. J. Hepatol. 2004, 41, 391-398.

[166] Mahla, R. S. Stem cells applications in regenerative medicine and disease therapeutics. Int. J. Cell Bio. 2016, 2016, 1-24.

[167] Smith Ashley, M.; Strange Kevin, B.; Yin Viravuth, P.; Maguire-Nguyen Katie, K.; Rando Thomas, A.; Zasloff Michael, A.; Strange Kevin, B.; Yin Viravuth, P.; Zasloff 
Michael, A. The protein tyrosine phosphatase 1B inhibitor MSI-1436 stimulates regeneration of heart and multiple other tissues. NPJ Regen Med. 2017, 2, 4.

[168] Perni, M.; Flagmeier, P.; Limbocker, R.; Aprile Francesco, A.; Galvagnion, C.; Heller Gabriella, T.; Meisl, G.; Chen Serene, W.; Kumita Janet, R.; Challa Pavan, K.; Cohen Samuel, I. A.; Mannini, B.; Knowles Tuomas, P. J.; Vendruscolo, M.; Dobson Christopher, M.; Perni, M.; Flagmeier, P.; Limbocker, R.; Aprile Francesco, A.; Heller Gabriella, T.; Meisl, G.; Chen Serene, W.; Kumita Janet, R.; Challa Pavan, K.; Cohen Samuel, I. A.; Mannini, B.; Knowles Tuomas, P. J.; Vendruscolo, M.; Dobson Christopher, M.; Cascella, R.; Cecchi, C.; Chiti, F.; Galvagnion, C.; Kirkegaard Julius, B.; Barbut, D.; Zasloff, M.; Nollen Ellen, A. A.; Cremades, N.; Knowles Tuomas, P. J.; Zasloff, M. Multistep Inhibition of $\alpha$-Synuclein Aggregation and Toxicity in Vitro and in Vivo by Trodusquemine. ACS Chem Biol. 2018, 13, 2308-2319.

[169] Limbocker, R.; Chia, S.; Ruggeri Francesco, S.; Perni, M.; Heller Gabriella, T.; Meisl, G.; Mannini, B.; Habchi, J.; Michaels Thomas, C. T.; Challa Pavan, K.; Ahn, M.; Casford Samuel, T.; Fernando, N.; Xu Catherine, K.; Kloss Nina, D.; Cohen Samuel, I. A.; Kumita Janet, R.; Knowles Tuomas, P. J.; Vendruscolo, M.; Dobson Christopher, M.; Cascella, R.; Cecchi, C.; Chiti, F.; Michaels Thomas, C. T.; Zasloff, M.; Linse, S.; Knowles Tuomas, P. J. Trodusquemine enhances A $\beta 42$ aggregation but suppresses its toxicity by displacing oligomers from cell membranes. Nat Commun. 2019, 10, 225.

[170] Malve, H. Exploring the ocean for new drug developments: Marine pharmacology. Journal of pharmacy \& bioallied sciences. 2016, 8, 83.

[171] Xu, M.; Davis, R. A.; Feng, Y.; Sykes, M. L.; Shelper, T.; Avery, V. M.; Camp, D.; Quinn, R. J. Ianthelliformisamines A-C, Antibacterial Bromotyrosine-Derived Metabolites from the Marine Sponge Suberea ianthelliformis. J. Nat. Prod. 2012, 75, 1001-1005.

[172] Fusetani, N.; Masuda, Y.; Nakao, Y.; Matsunaga, S.; van Soest, R. W. M. Three new bromotyrosine derivatives lethal to crab from the marine sponge, Pseudoceratina purpurea. Tetrahedron. 2001, 57, 7507-7511.

[173] Pieri, C.; Borselli, D.; Di Giorgio, C.; De Meo, M.; Bolla, J.-M.; Vidal, N.; Combes, S.; Brunel Jean, M. New Ianthelliformisamine derivatives as antibiotic enhancers against resistant Gram-negative bacteria. J Med Chem. 2014, 57, 4263-4272.

[174] Khan, F. A.; Ahmad, S.; Kodipelli, N.; Shivange, G.; Anindya, R. Syntheses of a library of molecules on the marine natural product ianthelliformisamines platform and their biological evaluation. Org. Biomol. Chem. 2014, 12, 3847-3865. 
[175] Choomuenwai, V.; Schwartz, B. D.; Beattie, K. D.; Andrews, K. T.; Khokhar, S.; Davis, R. A. The discovery, synthesis and antimalarial evaluation of natural productbased polyamine alkaloids. Tetrahedron Lett. 2013, 54, 5188-5191.

[176] Matsunaga, S.; Kishi, R.; Otsuka, K.; Fujita, M. J.; Oikawa, M.; Sakai, R. Protoaculeine B, a Putative N-Terminal Residue for the Novel Peptide Toxin Aculeines. Org. Lett. 2014, 16, 3090-3093.

[177] Matsunaga, S.; Sakai, R.; Jimbo, M.; Kamiya, H. Long-chain polyamines (LCPAs) from marine sponge: possible implication in spicule formation. ChemBioChem. 2007, 8 , 1729-1735.

[178] Shiozaki, H.; Miyahara, M.; Otsuka, K.; Takasaki, Y.; Takamizawa, S.; Tukada, H.; Ishikawa, Y.; Oikawa, M.; Miyako, K.; Honda, A.; Sakai, R. Studies on Aculeines: Synthetic Strategy to the Fully Protected Protoaculeine B, the N-Terminal Amino Acid of Aculeine B. Org Lett. 2018, 20, 3403-3407.

[179] Bridoux, M. C.; Annenkov, V. V.; Menzel, H.; Keil, R. G.; Ingalls, A. E. A new liquid chromatography/electrospray ionization mass spectrometry method for the analysis of underivatized aliphatic long- chain polyamines: application to diatom- rich sediments. Rapid Communications in Mass Spectrometry. 2011, 25, 877-888.

[180] Williams, D. E.; Lassota, P.; Andersen, R. J. Motuporamines A-C, Cytotoxic Alkaloids Isolated from the Marine Sponge Xestospongia exigua (Kirkpatrick). J. Org. Chem. 1998, 63, 4838-4841.

[181] Williams David, E.; Craig Kyle, S.; Patrick, B.; McHardy Lianne, M.; van Soest, R.; Roberge, M.; Andersen Raymond, J. Motuporamines, anti-invasion and anti-angiogenic alkaloids from the marine sponge Xestospongia exigua (Kirkpatrick): isolation, structure elucidation, analogue synthesis, and conformational analysis. J Org Chem. 2002, 67, 245-258.

[182] Goldring, W. P. D.; Weiler, L. Cytotoxic Alkaloids Motuporamines A-C: Synthesis and Structural Verification. Org. Lett. 1999, 1, 1471-1473.

[183] Baldwin, J. E.; Vollmer, H. R.; Lee, V. Total synthesis of cytotoxic sponge alkaloids motuporamines A and B. Tetrahedron Lett. 1999, 40, 5401-5404.

[184] Weston, M. H.; Nakajima, K.; Parvez, M.; Back, T. G. Ring-expansion of tertiary cyclic $\alpha$-vinylamines by tandem conjugate addition to ( $\mathrm{p}$-toluenesulfonyl) ethyne and formal 3-aza-Cope rearrangement. Chemical communications. 2006, 3903-3905. 
[185] Back, T. G. Design and synthesis of some biologically interesting natural and unnatural products based on organosulfur and selenium chemistry. Can. J. Chem. 2009, 87, 16571674.

[186] Marx, V. M.; Herbert, M. B.; Keitz, B. K.; Grubbs, R. H. Stereoselective Access to Z and E Macrocycles by Ruthenium-Catalyzed Z-Selective Ring-Closing Metathesis and Ethenolysis. J. Am. Chem. Soc. 2013, 135, 94-97.

[187] Fuerstner, A.; Rumbo, A. Ring-Closing Alkyne Metathesis. Stereoselective Synthesis of the Cytotoxic Marine Alkaloid Motuporamine C. J. Org. Chem. 2000, 65, 2608-2611.

[188] Zhou, L.; Li, Z.; Zou, Y.; Wang, Q.; Sanhueza, I. A.; Schoenebeck, F.; Goeke, A. Tandem Nucleophilic Addition/Oxy-2-azonia-Cope Rearrangement for the Formation of Homoallylic Amides and Lactams: Total Synthesis and Structural Verification of Motuporamine G. J. Am. Chem. Soc. 2012, 134, 20009-20012.

[189] Roskelley, C. D.; Williams, D. E.; McHardy, L. M.; Leong, K. G.; Troussard, A.; Karsan, A.; Andersen, R. J.; Dedhar, S.; Roberge, M. Inhibition of tumor cell invasion and angiogenesis by motuporamines. Cancer Res. 2001, 61, 6788-6794.

[190] McHardy, L. M.; Sinotte, R.; Troussard, A.; Sheldon, C.; Church, J.; Williams, D. E.; Andersen, R. J.; Dedhar, S.; Roberge, M.; Roskelley, C. D. The Tumor Invasion Inhibitor Dihydromotuporamine C Activates RHO, Remodels Stress Fibers and Focal Adhesions, and Stimulates Sodium-Proton Exchange. Cancer Res. 2004, 64, 1468-1474.

[191] Kaur, N.; Delcros, J.-G.; Martin, B.; Phanstiel, O. Synthesis and Biological Evaluation of Dihydromotuporamine Derivatives in Cells Containing Active Polyamine Transporters. J. Med. Chem. 2005, 48, 3832-3839.

[192] Breitbeil, F., III; Kaur, N.; Delcros, J.-G.; Martin, B.; Abboud, K. A.; Phanstiel, O. I. V. Modeling the Preferred Shapes of Polyamine Transporter Ligands and Dihydromotuporamine-C Mimics: Shovel versus Hoe. J. Med. Chem. 2006, 49, $2407-$ 2416.

[193] Muth, A.; Pandey, V.; Kaur, N.; Wason, M.; Baker, C.; Han, X.; Johnson, T. R.; Altomare, D. A.; Phanstiel, O. I. V. Synthesis and Biological Evaluation of Antimetastatic Agents Predicated upon Dihydromotuporamine C and Its Carbocyclic Derivatives. J. Med. Chem. 2014, 57, 4023-4034.

[194] Borselli, D.; Blanchet, M.; Bolla, J.-M.; Muth, A.; Skruber, K.; Phanstiel, O. I. V.; Brunel, J. M. Motuporamine Derivatives as Antimicrobial Agents and Antibiotic Enhancers against Resistant Gram-Negative Bacteria. ChemBioChem. 2017, 18, 276283. 
[195] Skruber, K.; Chaplin Kelvin, J.; Phanstiel Otto, t. Synthesis and Bioevaluation of Macrocycle-Polyamine Conjugates as Cell Migration Inhibitors. J Med Chem. 2017, 60, 8606-8619.

[196] Barbeau, K.; Zhang, G.; Live David, H.; Butler, A. Petrobactin, a photoreactive siderophore produced by the oil-degrading marine bacterium Marinobacter hydrocarbonoclasticus. J Am Chem Soc. 2002, 124, 378-379.

[197] Correnti, C.; Strong, R. K. Iron Sequestration in Immunity. Encycl. Inorg. Bioinorg. Chem. 2013, 1-11.

[198] Koppisch, A. T.; Browder, C. C.; Moe, A. L.; Shelley, J. T.; Kinkel, B. A.; Hersman, L. E.; Iyer, S.; Ruggiero, C. E. Petrobactin is the primary siderophore synthesized by Bacillus anthracis Str. Sterne under conditions of iron starvation. BioMetals. 2005, 18, 577-585.

[199] Abergel, R. J.; Zawadzka, A. M.; Raymond, K. N. Petrobactin-Mediated Iron Transport in Pathogenic Bacteria: Coordination Chemistry of an Unusual 3,4-Catecholate/Citrate Siderophore. J. Am. Chem. Soc. 2008, 130, 2124-2125.

[200] Hickford, S. J. H.; Kuepper, F. C.; Zhang, G.; Carrano, C. J.; Blunt, J. W.; Butler, A. Petrobactin Sulfonate, a New Siderophore Produced by the Marine Bacterium Marinobacter hydrocarbonoclasticus. J. Nat. Prod. 2004, 67, 1897-1899.

[201] Homann Vanessa, V.; Edwards Katrina, J.; Webb Eric, A.; Butler, A. Siderophores of Marinobacter aquaeolei: petrobactin and its sulfonated derivatives. Biometals. 2009, 22, $565-571$.

[202] Bergeron, R. J.; Huang, G.; Smith, R. E.; Bharti, N.; McManis, J. S.; Butler, A. Total synthesis and structure revision of petrobactin. Tetrahedron. 2003, 59, 2007-2014.

[203] Barbeau, K.; Rue, E. L.; Trick, C. G.; Bruland, K. W.; Butler, A. Photochemical reactivity of siderophores produced by marine heterotrophic bacteria and cyanobacteria based on characteristic Fe(III) binding groups. Limnol. Oceanogr. 2003, 48, 1069-1078.

[204] Zhang, G.; Amin, S. A.; Kupper, F. C.; Holt, P. D.; Carrano, C. J.; Butler, A. Ferric Stability Constants of Representative Marine Siderophores: Marinobactins, Aquachelins, and Petrobactin. Inorg. Chem. 2009, 48, 11466-11473.

[205] Harris, W. R.; Amin, S. A.; Kuepper, F. C.; Green, D. H.; Carrano, C. J. Borate Binding to Siderophores: Structure and Stability. J. Am. Chem. Soc. 2007, 129, 12263-12271.

[206] Zheng, T.; Nolan, E. M. Siderophore-based detection of Fe(iii) and microbial pathogens. Metallomics. 2012, 4, 866-880. 
[207] Bugdahn, N.; Peuckert, F.; Albrecht Alexander, G.; Miethke, M.; Marahiel Mohamed, A.; Oberthur, M. Direct identification of a siderophore import protein using synthetic petrobactin ligands. Angew Chem Int Ed Engl. 2010, 49, 10210-10213.

[208] Hagan, A. K.; Berger, D.; Hanna, P. C.; Tripathi, A.; Sherman, D. H. Petrobactin Is Exported from Bacillus anthracis by the RND-Type Exporter ApeX. mBio. 2017, 8.

[209] Gardes, A.; Triana, C.; Amin Shady, A.; Green David, H.; Romano, A.; Trimble, L.; Carrano Carl, J. Detection of photoactive siderophore biosynthetic genes in the marine environment. Biometals. 2013, 26, 507-516.

[210] Yarimizu, K.; Polido, G.; Gaerdes, A.; Carter, M. L.; Hilbern, M.; Carrano, C. J. Evaluation of photo-reactive siderophore producing bacteria before, during and after a bloom of the dinoflagellate Lingulodinium polyedrum. Metallomics. 2014, 6, 11561163.

[211] Gardner Richard, A.; Kinkade, R.; Wang, C.; Phanstiel Otto, t. Total synthesis of petrobactin and its homologues as potential growth stimuli for Marinobacter hydrocarbonoclasticus, an oil-degrading bacteria. J Org Chem. 2004, 69, 3530-3537.

[212] Pandey, R. K.; Jarvis, G. G.; Low, P. S. Efficient synthesis of the siderophore petrobactin via antimony triethoxide mediated coupling. Tetrahedron Lett. 2012, 53, $1627-1629$.

[213] Bugdahn, N.; Oberthuer, M. Syntheses and Iron Binding Affinities of the Bacillus anthracis Siderophore Petrobactin and Side-Chain-Modified Analogues. Eur. J. Org. Chem. 2014, 2014, 426-435.

[214] Abergel, R. J.; Wilson, M. K.; Arceneaux, J. E. L.; Hoette, T. M.; Strong, R. K.; Byers, B. R.; Raymond, K. N. Anthrax pathogen evades the mammalian immune system through stealth siderophore production. Proc. Natl. Acad. Sci. U. S. A. 2006, 103, 18499-18503.

[215] Cendrowski, S.; MacArthur, W.; Hanna, P. Bacillus anthracis requires siderophore biosynthesis for growth in macrophages and mouse virulence. Molecular microbiology. 2004, 51, 407-417.

[216] Koppisch Andrew, T.; Dhungana, S.; Hill Karen, K.; Boukhalfa, H.; Heine Henry, S.; Colip Leslie, A.; Romero Raymond, B.; Shou, Y.; Ticknor Lawrence, O.; Marrone Babetta, L.; Hersman Larry, E.; Iyer, S.; Ruggiero Christy, E. Petrobactin is produced by both pathogenic and non-pathogenic isolates of the Bacillus cereus group of bacteria. Biometals. 2008, 21, 581-589. 
[217] Dauner, M.; Eichinger, A.; Skerra, A.; Lucking, G.; Scherer, S. Reprogramming Human Siderocalin To Neutralize Petrobactin, the Essential Iron Scavenger of Anthrax Bacillus. Angew Chem Int Ed Engl. 2018, 57, 14619-14623.

[218] Lee, J. Y.; Janes, B. K.; Passalacqua, K. D.; Pfleger, B. F.; Bergman, N. H.; Liu, H.; Hakansson, K.; Somu, R. V.; Aldrich, C. C.; Cendrowski, S.; Hanna, P. C.; Sherman, D. H. Biosynthetic analysis of the petrobactin siderophore pathway from Bacillus anthracis. J. Bacteriol. 2007, 189, 1698-1710.

[219] Oves-Costales, D.; Kadi, N.; Fogg, M. J.; Song, L.; Wilson, K. S.; Challis, G. L. Enzymatic Logic of Anthrax Stealth Siderophore Biosynthesis: AsbA Catalyzes ATPDependent Condensation of Citric Acid and Spermidine. J. Am. Chem. Soc. 2007, 129, 8416-8417.

[220] Pfleger Brian, F.; Lee Jung, Y.; Somu Ravindranadh, V.; Aldrich Courtney, C.; Hanna Philip, C.; Sherman David, H. Characterization and analysis of early enzymes for petrobactin biosynthesis in Bacillus anthracis. Biochemistry. 2007, 46, 4147-4157.

[221] Koppisch Andrew, T.; Hotta, K.; Fox David, T.; Ruggiero Christy, E.; Kim, C.-Y.; Sanchez, T.; Iyer, S.; Browder Cindy, C.; Unkefer Pat, J.; Unkefer Clifford, J. Biosynthesis of the 3,4-dihydroxybenzoate moieties of petrobactin by Bacillus anthracis. J Org Chem. 2008, 73, 5759-5765.

[222] Oves-Costales, D.; Kadi, N.; Fogg Mark, J.; Song, L.; Wilson Keith, S.; Challis Gregory, L. Petrobactin biosynthesis: AsbB catalyzes condensation of spermidine with N8-citryl-spermidine and its N1-(3,4-dihydroxybenzoyl) derivative. Chem Commun (Camb). 2008, 4034-4036.

[223] Pfleger, B. F.; Kim, Y.; Nusca, T. D.; Maltseva, N.; Lee, J. Y.; Rath, C. M.; Scaglione, J. B.; Janes, B. K.; Anderson, E. C.; Bergman, N. H.; Hanna, P. C.; Joachimiak, A.; Sherman, D. H. Structural and functional analysis of AsbF: origin of the stealth 3,4dihydroxybenzoic acid subunit for petrobactin biosynthesis. Proc. Natl. Acad. Sci. U. S. A. 2008, 105, 17133-17138.

[224] Oves-Costales, D.; Song, L.; Challis Gregory, L. Enantioselective desymmetrisation of citric acid catalysed by the substrate-tolerant petrobactin biosynthetic enzyme AsbA. Chem Commun (Camb). 2009, 1389-1391.

[225] Nusca, T. D.; Kim, Y.; Maltseva, N.; Lee, J. Y.; Eschenfeldt, W.; Stols, L.; Schofield, M. M.; Scaglione, J. B.; Dixon, S. D.; Oves-Costales, D.; Challis, G. L.; Hanna, P. C.; Pfleger, B. F.; Joachimiak, A.; Sherman, D. H. Functional and Structural Analysis of the 
Siderophore Synthetase AsbB through Reconstitution of the Petrobactin Biosynthetic Pathway from Bacillus anthracis. J. Biol. Chem. 2012, 287, 16058-16072.

[226] Hotta, K.; Kim, C.-Y.; Fox, D. T.; Koppisch, A. T. Siderophore-mediated iron acquisition in Bacillus anthracis and related strains. Microbiology. 2010, 156, 19181925.

[227] Sheng, M.; Jia, H.; Tao, X.; Zeng, L.; Zhang, T.; Hu, Z.; And, Z. Z.; Liu, H. Mining, isolation and identification of siderophore synthesis gene from Brevibacillus brevis GZDF3. Am. J. Biochem. Biotechnol. 2018, 14, 200-209.

[228] Daas, M. S.; Rosana, A. R. R.; Acedo, J. Z.; Douzane, M.; Nateche, F.; KebboucheGana, S.; Vederas, J. C. Insights into the draft genome sequence of bioactivesproducing Bacillus thuringiensis DNG9 isolated from Algerian soil-oil slough. Stand. Genomic Sci. 2018, 13, 25.

[229] Zawadzka Anna, M.; Kim, Y.; Maltseva, N.; Nichiporuk, R.; Fan, Y.; Joachimiak, A.; Raymond Kenneth, N. Characterization of a Bacillus subtilis transporter for petrobactin, an anthrax stealth siderophore. Proc Natl Acad Sci U S A. 2009, 106, 21854-21859.

[230] Zawadzka, A. M.; Abergel, R. J.; Nichiporuk, R.; Andersen, U. N.; Raymond, K. N. Siderophore-mediated iron acquisition systems in Bacillus cereus: Identification of receptors for anthrax virulence-associated petrobactin. Biochemistry. 2009, 48, 36453657.

[231] Carlson, P. E., Jr.; Dixon, S. D.; Janes, B. K.; Carr, K. A.; Nusca, T. D.; Anderson, E. C.; Keene, S. E.; Sherman, D. H.; Hanna, P. C. Genetic analysis of petrobactin transport in Bacillus anthracis. Mol. Microbiol. 2010, 75, 900-909.

[232] Pi, H.; Helmann, J. D. Sequential induction of Fur-regulated genes in response to iron limitation in Bacillus subtilis. Proc. Natl. Acad. Sci. U. S. A. 2017, 114, 12785-12790.

[233] Dixon Shandee, D.; Janes Brian, K.; Bourgis, A.; Carlson Paul, E., Jr.; Hanna Philip, C. Multiple $\mathrm{ABC}$ transporters are involved in the acquisition of petrobactin in Bacillus anthracis. Mol Microbiol. 2012, 84, 370-382.

[234] Hagan, A. K.; Hanna, P. C.; Carlson, P. E., Jr. Flying under the radar: The noncanonical biochemistry and molecular biology of petrobactin from Bacillus anthracis. Mol Microbiol. 2016, 102, 196-206.

[235] Hagan, A. K.; Plotnick, Y. M.; Dingle, R. E.; Mendel, Z. I.; Cendrowski, S. R.; Sherman, D. H.; Tripathi, A.; Hanna, P. C. Petrobactin protects against oxidative stress and enhances sporulation efficiency in Bacillus anthracis sterne. mBio. 2018, 9, e02079/02071-e02079/02014. 
[236] Lee, J. Y.; Passalacqua, K. D.; Hanna, P. C.; Sherman, D. H. Regulation of petrobactin and bacillibactin biosynthesis in Bacillus anthracis under iron and oxygen variation. PLoS One. 2011, 6, e20777.

[237] Steglich, W.; Steffan, B.; Stroech, K.; Wolf, M. Pistillarin, a characteristic metabolite of Clavariadelphus pistillaris and several Ramaria species (Basidiomycetes). $Z$. Naturforsch., C Biosci. 1984, 39C, 10-12.

[238] Capon, R. J.; Stewart, M.; Ratnayake, R.; Lacey, E.; Gill, J. H. Citromycetins and bilains A-C: new aromatic polyketides and diketopiperazines from Australian marinederived and terrestrial Penicillium spp. J. Nat. Prod. 2007, 70, 1746-1752.

[239] Li, L.-F.; Chan, B. C.-L.; Yue, G. G.-L.; Lau, C. B.-S.; Han, Q.-B.; Leung, P.-C.; Liu, J.-K.; Fung, K.-P. Two immunosuppressive compounds from the mushroom Rubinoboletus ballouii using human peripheral blood mononuclear cells by bioactivityguided fractionation. Phytomedicine. 2013, 20, 1196-1202.

[240] Lee, I.-K.; Ki, D.-W.; Kim, S.-E.; Yeom, J.-H.; Kim, Y.-S.; Yun, B.-S. Pistillarin salt, a dicatecholspermidine family member from Gomphus floccosus, inhibits DNA single strand breakage by the Fenton reaction. J. Korean Soc. Appl. Biol. Chem. 2011, 54, 312315 .

[241] Pine, E. M.; Hibbett, D. S.; Donoghue, M. J. Phylogenetic relationships of cantharelloid and clavarioid Homobasidiomycetes based on mitochondrial and nuclear rDNA sequences. Mycologia. 1999, 91, 944-963.

[242] Vidovic, S.; Zekovic, Z.; Jokic, S. Clavaria Mushrooms and Extracts: Investigation on Valuable Components and Antioxidant Properties. Int. J. Food Prop. 2014, 17, $2072-$ 2081.

[243] Sharma, S. K.; Miller, M. J.; Payne, S. M. Spermexatin and spermexatol: new synthetic spermidine-based siderophore analogs. Journal of medicinal chemistry. 1989, 32, 357 367.

[244] Reissbrodt, R.; Ramiandrasoa, F.; Bricard, L.; Kunesch, G. Siderophore activity of chemically synthesized dihydroxybenzoyl derivatives of spermidines and cystamide. BioMetals. 1997, 10, 95-103.

[245] Holinsworth, B.; Martin, J. D. Siderophore production by marine-derived fungi. BioMetals. 2009, 22, 625-632.

[246] El Hage Chahine, J.-M.; Bauer, A.-M.; Baraldo, K.; Lion, C.; Ramiandrasoa, F.; Kunesch, G. Kinetics and thermodynamics of complex formation between FeIII and two 
synthetic chelators of the dicatecholspermidine family. Eur. J. Inorg. Chem. 2001, 2287-2296.

[247] Beattie, K. D.; Ellwood, N.; Kumar, R.; Yang, X.; Healy, P. C.; Choomuenwai, V.; Quinn, R. J.; Elliott, A. G.; Huang, J. X.; Chitty, J. L.; Fraser, J. A.; Cooper, M. A.; Davis, R. A. Antibacterial and antifungal screening of natural products sourced from Australian fungi and characterization of pestalactams D-F. Phytochemistry (Elsevier). 2016, 124, 79-85.

[248] Parr Adrian, J.; Mellon Fred, A.; Colquhoun Ian, J.; Davies Howard, V. Dihydrocaffeoyl polyamines (kukoamine and allies) in potato (Solanum tuberosum) tubers detected during metabolite profiling. J Agric Food Chem. 2005, 53, 5461-5466.

[249] Li, Y.-Y.; Di, R.; Baibado, J. T.; Cheng, Y.-S.; Huang, Y.-Q.; Sun, H.; Cheung, H.-Y. Identification of kukoamines as the novel markers for quality assessment of Lycii Cortex. Food Res. Int. 2014, 55, 373-380.

[250] Funayama, S.; Yoshida, K.; Konno, C.; Hikino, H. Structure of kukoamine A, a hypotensive principle of Lycium chinense root barks. Tetrahedron Lett. 1980, 21, 13551356.

[251] Chantrapromma, K.; Ganem, B. Chemistry of naturally-occurring polyamines. 4. Total synthesis of kukoamine A, an antihypertensive constituent of Lycium chinense. Tetrahedron Lett. 1981, 22, 23-24.

[252] Page, P.; Burrage, S.; Baldock, L.; Bradley, M. The synthesis of symmetrical spermine conjugates using solid-phase chemistry. Bioorg. Med. Chem. Lett. 1998, 8, 1751-1756.

[253] Garnelis, T.; Athanassopoulos, C. M.; Papaioannou, D.; Eggleston, I. M.; Fairlamb, A. H. Very short and efficient syntheses of the spermine alkaloid kukoamine A and analogs using isolable succinimidyl cinnamates. Chem. Lett. 2005, 34, 264-265.

[254] Piletska Elena, V.; Burns, R.; Terry Leon, A.; Piletsky Sergey, A. Application of a molecularly imprinted polymer for the extraction of kukoamine a from potato peels. $J$ Agric Food Chem. 2012, 60, 95-99.

[255] Ponasik, J. A.; Strickland, C.; Faerman, C.; Savvides, S.; Karplus, P. A.; Ganem, B. Kukoamine A and other hydrophobic acylpolyamines: potent and selective inhibitors of Crithidia fasciculata trypanothione reductase. Biochem. J. 1995, 311, 371-375.

[256] Hu, X.-L.; Gao, L.-Y.; Niu, Y.-X.; Tian, X.; Wang, J.; Meng, W.-H.; Zhang, Q.; Cui, C.; Han, L.; Zhao, Q.-C. Neuroprotection by Kukoamine A against oxidative stress may involve N-methyl-D-aspartate receptors. Biochim. Biophys. Acta, Gen. Subj. 2015, $1850,287-298$. 
[257] Li, Y.-Y.; Hu, S.; Huang, Y.-Q.; Han, Y.; Cheung, H.-Y. Preventing H2O2-induced toxicity in primary cerebellar granule neurons via activating the PI3-K/Akt/GSK3 $\beta$ pathway by kukoamine from Lycii Cortex. J. Funct. Foods. 2015, 17, 709-721.

[258] Li, X.; Lin, J.; Chen, J.; Xie, H.; Chen, D. Antioxidant and cytoprotective effects of kukoamines A and B: comparison and positional isomeric effect. Molecules. 2018, 23, 973/971-973/914.

[259] Wang, Q.; Li, H.; Sun, Z.; Dong, L.; Gao, L.; Liu, C.; Wang, X. Kukoamine A inhibits human glioblastoma cell growth and migration through apoptosis induction and epithelial-mesenchymal transition attenuation. Sci. Rep. 2016, 6, 36543.

[260] Zhang, Y.; Cheng, Z.; Wang, C.; Ma, H.; Meng, W.; Zhao, Q. Neuroprotective Effects of Kukoamine a against Radiation-induced Rat Brain Injury through Inhibition of Oxidative Stress and Neuronal Apoptosis. Neurochem. Res. 2016, 41, 2549-2558.

[261] Zhang, Y.; Cai, J.; Zhao, Q.; Gao, L.; Niu, Y.; Meng, W.; Cheng, Z. Kukoamine A Prevents Radiation-Induced Neuroinflammation and Preserves Hippocampal Neurogenesis in Rats by Inhibiting Activation of NF-кB and AP-1. Neurotox Res. 2017, 31, 259-268.

[262] Liu, J.; Jiang, X.; Hu, X.; Zhang, Q.; Zhu, J.; Zhang, Y.; Du, J.; Lin, S.; Meng, W.; Zhao, Q. Neuroprotective effects of Kukoamine A against cerebral ischemia via antioxidant and inactivation of apoptosis pathway. Neurochem Int. 2017, 107, 191-197.

[263] Jiang, G.; Takase, M.; Aihara, Y.; Shigemori, H. Inhibitory activities of kukoamines A and B from Lycii Cortex on amyloid aggregation related to Alzheimer's disease and type 2 diabetes. J. Nat. Med. 2020, 74, 247-251.

[264] Hu, X.; Song, Q.; Li, X.; Li, D.; Zhang, Q.; Meng, W.; Zhao, Q. Neuroprotective effects of Kukoamine A on neurotoxin-induced Parkinson's model through apoptosis inhibition and autophagy enhancement. Neuropharmacology. 2017, 117, 352-363.

[265] Li, G.; Zhou, F.; Chen, Y.; Zhang, W.; Wang, N. Kukoamine A attenuates insulin resistance and fatty liver through downregulation of Srebp-1c. Biomed. Pharmacother. 2017, 89, 536-543.

[266] Moreau, R. A.; Nunez, A.; Singh, V. Diferuloylputrescine and p-coumaroylferuloylputrescine, abundant polyamine conjugates in lipid extracts of maize kernels. Lipids. 2001, 36, 839-844.

[267] Choi Sang, W.; Lee Sung, K.; Kim Eun, O.; Oh Ji, H.; Yoon Kyung, S.; Parris, N.; Hicks Kevin, B.; Moreau Robert, A. Antioxidant and antimelanogenic activities of 
polyamine conjugates from corn bran and related hydroxycinnamic acids. J Agric Food Chem. 2007, 55, 3920-3925. 